\title{
FORTIFICACIONES CAMPAMENTALES DE ÉPOCA ROMANA EN ESPAÑA
}

\author{
POR \\ ÁNGEL MORILLO CERDÁN \\ Departamento de Prehistoria y Arqueología. Universidad Autónoma. Madrid
}

\begin{abstract}
RESUMEN
Las publicaciones sobre campamentos militares de época romana en España resultan escasas y, en su mayoría, antiguas. Carecemos de obras de conjunto referentes a los elementos defensivos construidos en dichos recintos. En este trabajo he tratado de analizar de forma crítica, y desde una perspectiva histórica y arqueológica, la bibliografía existente. Es posible extraer unas mínimas conclusiones acerca de las fortificaciones castrenses romanas en España, que no siempre coinciden con las observaciones realizadas en yacimientos nordeuropeos.
\end{abstract}

\section{SUMMARY}

The publications about roman age military camps in Spain seem to limited and too old actually. We lack of linked publications about defensive elements built up in those areas. I have tried with this work to analize critically as well as historically and archaelogically the existing bibliography. It is possible to extract several conclussions about the roman military fortresses in Spain, which do not coincide, many times, with those observations carried out in Northern Europe settlements.

\section{LAS FUENTES ESCRITAS DE ÉPOCA ROMANA}

Los textos clásicos que contienen referencias a asentamientos castrenses son muy numerosos dentro de la historiografía romana contemporánea, y poseen, asimismo, un carácter muy variado. Las referencias aparecen indistintamente en obras de historia, arquitectura, campañas militares o fortificación ciudadana. Sólo tenemos un ejemplo dedicado específicamente a la construcción de recintos campamentales, el texto atribuido a Higinio, más conocido como pseudohiginio, De Metatione Castrorum o De Munitionibus Castrorum. Al parecer fue redactada por un gromático o agrimensor romano, alistado en el ejército romano durante las campañas dácicas de Trajano.

Polibio, que vivió de cerca varias campañas de Escipión a mediados del siglo II a. C. des- 
cribe un campamento contemporáneo en el libro VI de sus Historias (capítulos 26, 10 a 42, 6 inclusive). Constituye junto con la obra anteriormente citada los dos textos principales para el conocimiento de la técnica de castramentación romana.

Junto con Polibio e Higinio existen otras fuentes secundarias, que aportan datos puntuales y escogidos, aunque no por ello menos interesantes. Entre éstas podemos citar a Tito Livio (Ah Urbe Condita), César (De Bello Civile y De Bello Galico), Vegecio (Epitome rei militari), Vitrubio (De Architectura). Flavio Josefo (Bellum Iudaicum), Julio Africano (Cestes), León el Filósofo (Instituciones militares), así como el perdido De rei militari de Frontino.

Las obras de Polibio e Higinio se encuentran separadas por un período de casi tres siglos, pero describen campamentos muy similares, cuadrangulares, con una organización ortogonal por medio de dos vías principales (Praetoria y Principalis), que se cruzan delante del cuartel general Praetorium o Principia, flanqueado por el Forum y el Quaestorium (Polibio VI, 31, 1). Suele existir además una tercera vía de importancia, la denominada via Quintana, paralela a la via Principalis. Se configura siguiendo una estructura tripartita (Lenoir, 1986, 330). Las diferencias entre Polibio e Higinio se centran en la forma del recinto. El primero asegura que debe ser cuadrado (Polibio, VI, 31, 10). El segundo, rectangular (Higinio, 21). La evolución del campamento republicano cuadrado hacia otro rectangular parece obedecer a las transformaciones en el ejército romano tradicional, llevadas a cabo por Mario y consolidadas por César (Masquelez, 1887, 949).

En algunas ocasiones las fuentes clásicas recogen campamentos de forma irregular, casi siempre determinados por la naturaleza del terreno o alguna necesidad concreta. Conocemos así los castra necessaria, donde la topografía obligaba a construir una empalizada irregular (Higinio, De Metatione..., 56; César, De Bello Galico VII, 83, y De Bello Civile, I, 81); castra lunata, en forma de creciente lunar; castra semirotunda, sobre la curva de un rio, en un istmo o en la confluencia de dos cursos de agua (Vegecio, Epitome rei militari, I, 23); castra tumultuaria, sobre una eminencia del terreno. Vegecio, escritor bajoimperial, ya considera la adaptación al terreno circundante más importante que la forma concreta (Vegecio, I, 23).

No podemos detenernos aquí en cuestiones como la distribución del espacio interior dentro de los campamentos o el origen de los mismos. En cualquier caso la forma de estos asentamientos tiene un origen autóctono, muy vinculada a la práctica augural y a la limitatio o esquema de organización del territorio. Su similitud con la planta de la ciudad resulta un hecho a tener en cuenta al respecto.

Respecto al tema concreto de las fortificaciones campamentales tenemos un buen número de referencias. La defensa principal del campamento debe consistir en un agger o conjunto de foso, terraplen y empalizada, con un intervallum intramuros (Polibio VI, 34, 1, 34, 11 y 34 , 14; Higinio, 14 y 49). Contamos, asimismo, con citas puntuales proporcionadas por diferentes autores sobre cuestiones como la forma de la fosa (Higinio, 49; César, De Bello Galico V, 40, VII, 72, VIII, 9), la construcción de la empalizada, o la anchura del camino de ronda (Vitrubio, De Architectura I, V, 3).

La mayor parte de los datos corresponden a construcciones en madera. Carecemos de textos sobre campamentos estables realizados en piedra. Podemos pensar que el modelo teórico ideal de edificación de murallas para ciudades, contenido en los capítulos V y VI del libro I de Vitrubio, pudo aplicarse en algunos casos a la castramentación militar. La arqueología confirma que cuando los campamentos temporales se petrifican a finales del siglo I o principios 
del Il d. C.. conservan la mayor parte de sus caracteristicas constructivas, a pesar de las lógicas modificaciones (Jones, 1975, 97).

\section{ESTUDIO ARQUEOLÓGICO DE LAS FORTIFICACIONES CASTRENSES}

\section{Estado de la cuestión}

En este punto quiero tratar brevemente el estado del conocimiento sobre las fortificaciones campamentales de época romana a través de las últimas publicaciones. La bibliografía española es prácticamente inexistente. No se ha excavado concienzudamente ningún recinto a excepción de Numancia, a principios de siglo, y Cáceres el Viejo en los años ochenta (Ulbert, 1984). No hay obras de sintesis. Por otro lado la escase de recintos campamentales conservados tal cual y bien fechados, hace bastante inviable un estudio completo del tema en nuestro país.

Los investigadores ingleses y alemanes han elaborado grandes corpora de campamentos. La presencia de un limes estable en estos paises a lo largo de varios siglos determina que tales asentamientos sean muy abundantes. Se han estudiado científicamente gran número de ellos. lo que ha posibilitado posteriormente la redacción de trabajos dedicados a diversas cuestiones, entre ellas las obras de fortificación. Quizá sean los ingleses los que más atención están prestando en la actualidad a esta cuestión, y son los que vamos a seguir en este estudio. La bibliografía alemana es algo anterior y presenta mayores problemas de acceso, debido a la dificultad del idioma, aunque no podemos cuestionar su calidad.

Las excavaciones llevadas a cabo en numerosos yacimientos ingleses han venido a corroborar en algunos casos, y completar en otros, las escasas noticias proporcionadas por las fuentes sobre disposición de defensas en campamentos romanos. Una de las primeras cuestiones

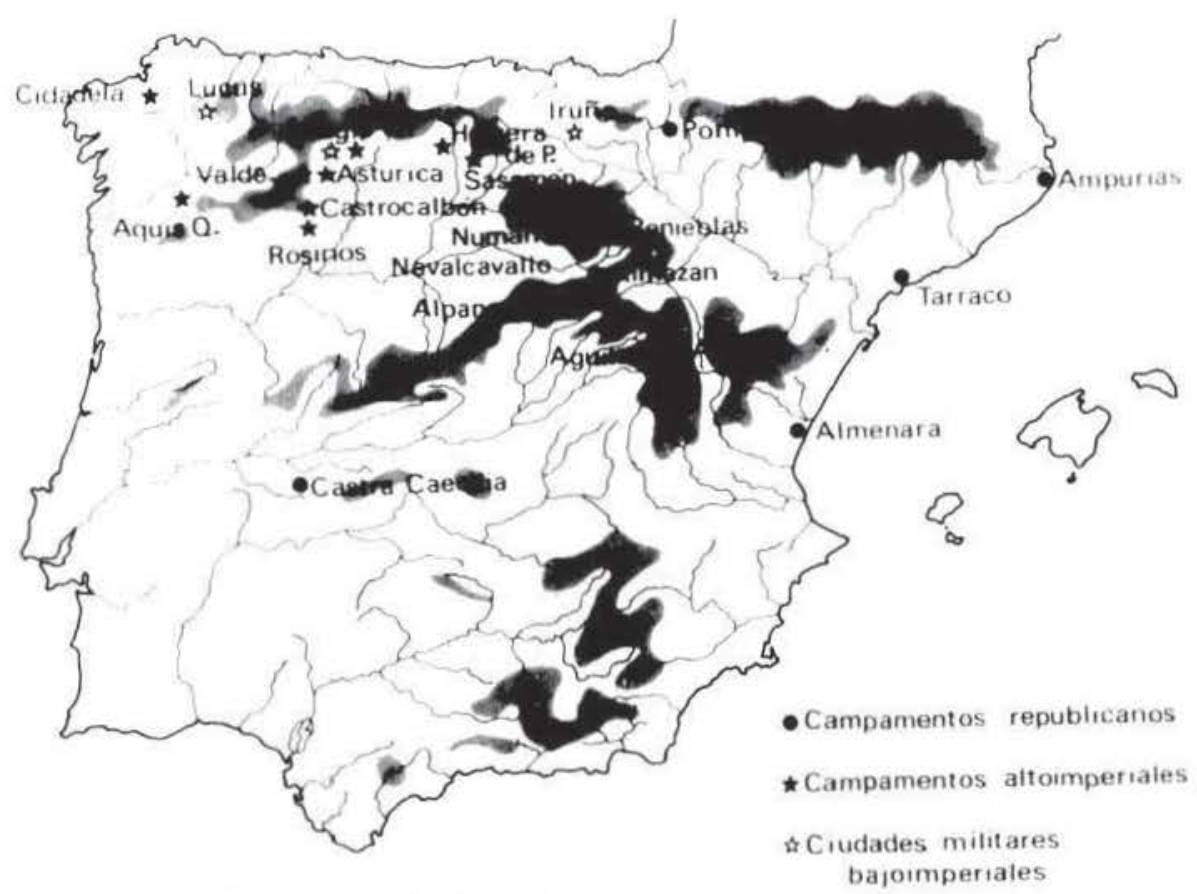

Figura 1.-Distribución de campamentos en España. 
planteadas, nunca aclarada en los textos clásicos, es la diferencia arqueológica entre campamento temporal y campamento estable. Ambos términos pueden ser sinónimos, pero conviene establecer una diferencia, aunque sea conceptual. Wilson distingue entre "campamento" y "fuerte». El primero es un establecimiento con defensas poco potentes, consistentes normalmente en un agger: que sacrifica la regularidad en aras del aprovechamiento de las defensas naturales del terreno (Wilson, 1980, 10-11): el fuerte es una base permanente para 500 soldados, que viven en barracas, dispuesto sobre una posición estratégica muy meditada, y con defensas más desarrolladas. Los ejemplos ingleses suelen constar de dos fosos y un muro de piedra almenado y reforzado en su cara interna con un terraplén. Wilson señala que en las fases más antiguas, el muro pétreo puede haber sido de madera (Wilson, 1980,13). Se dota asimismo de torres y torretas, cuatro puertas, esquinas redondeadas, edificios bien definidos intra y extramuros para el servicio del ejército, etc. (Wilson, 1980, 13-21).

Aunque los términos empleados constituyan una elección personal de Wilson, no cabe duda que corresponden a diferencias apreciables materialmente. Tenemos por un lado los campamentos temporales, de reducido tamaño y construidos en madera; por otro los campamentos fijos, de grandes dimensiones y defensas potentes. No parece que los segundos correspondan a una petrificación de los primeros, sino que sus diferencias residen más en su tamaño y su funcionalidad que en el material de construcción de sus defensas. Es decir, existían los recintos de madera para un corto período de tiempo, que no prestaban excesiva atención a las condiciones del entorno y a la disposición interna, y también existirían campamentos de grandes dimensiones, cuidadosamente planificados, que en un principio eran de madera y luego se petrifican. Jones asegura que la sustitución de empalizadas de madera por muros de piedra tiene lugar en época de Claudio-Neron en el limes renano, mientras en Gran Bretaña no se constata hasta época de Trajano (Jones, 1975, 97). Esta distinción general, que parece verosímil en el norte de Europa, no lo es tanto en el caso español. Se han documentado varios campamentos republicanos con murallas de piedra, y en bastantes casos desconocemos si los recintos imperiales pasaron por una fase anterior a su erección en piedra y hormigón.

Jones asegura que las fortificaciones eran lo primero en edificarse, una vez elegido el emplazamiento del campamento y determinado el trazado interno del mismo (Jones, 1975, 29). Este autor ofrece uno de los estudios más serios y rigurosos a partir de los datos obtenidos en excavaciones realizadas en numerosos yacimientos. La construcción comenzaba con la excavación del foso y el levantamiento del terraplén coronado por una empalizada. Estos tres elementos constituyen el denominado agger. Las puertas eran provisionales en principio, y las torres se dejaban para el final. El material del terraplén son bloques de arcilla cubiertos con tierra o turba, que no siempre procede del foso. Su anchura está en relación con la de la empalizada y las necesidades del camino de ronda superior (Jones, 1975, 30-32; A. Johnson, 1983, 58). Suele medir alrededor de seis metros (Jones, 1975, 70). La inclinación del terraplén es de 65-75 grados respecto a la horizontal, y la zona intramuros suele ser más alta que la exterior, y en un ángulo menor a partir del camino de ronda, entre 40-45 grados (Jones, 1975, 32). Sobre el terraplén se erige la empalizada o vallum, a base de postes de madera clavados en el suelo y atados entre sí, con una altura que oscila entre 3,3 y 4 metros. El camino interior de ronda se forra con madera y presenta accesos por escaleras, que suben por la cara interna del terraplén (Jones, 1975, 83-88). Johnson también nos ilustra con una disposición semejante (A. Johnson, 1983, 59-66).

Las defensas temporales se petrifican en Gran Bretaña desde el reinado de Trajano (Jones, 1975 , 
97; Johnson, 1983, 69). Wilson asegura que el cambio tiene lugar a lo largo del siglo Il y se ejemplifican en recintos como Inchtuthil y Caerleon (Wilson, 1980, 41-42). En algunas ocasiones se superpone el muro de piedra a la empalizada de madera (Jones, 1975, 86). Los muros pueden adoptar aparejos y técnicas constructivas muy distintas. Normalmente consisten en dos filas paralelas de piedras rellenas con tierra y sujetas por tirantes de madera. Es lo que se conoce con el nombre de murus gallicus. El relleno puede ser hormigón. La piedra está trabajada en forma de sillares o mampostería, en bloques bien escuadrados y regulares (A. Johnson, 1983, 66-71).

La parte externa del terraplén o muralla se protege con uno o varios fosos (fossae). A. Johnson documenta unas anchuras de 3,7 a 5 metros en los campamentos ingleses (Johnson, 1983, 48). Aunque el reconocimiento actual de los fosos resulta bastante complicado, parece que adoptaron distintas morfologías, lo que respondería a la información proporcionada por las fuentes escritas (Higinio, 49). La elección del tipo estaría en función de las necesidades concretas y las características del terreno. La más frecuente sería la Fastigata. Se presentan en número no uniforme alrededor del circuito, protegiendo las caras más expuestas y combinados a veces con obstáculos tales como estacas hincadas (Jones, 1975, 105-111).

Las fortificaciones están reforzadas con otros elementos. El más importante son las torres, que se disponen a intervalos regulares alrededor del perímetro, en los ángulos del mismo y flanqueando la puerta (Jones, 1975, 89; A. Johnson, 1983, 72). En los recintos de madera las torres son del mismo material, de planta muy variada: rectangulares, cuadradas o poligonales, y de tamaño no estandarizado (Jones, 1975, 92-3, 96). Este tipo de torres se sujetan en el terraplén mediante postes en el subsuelo, y se elevan con un piso por encima del camino de ronda para gozar de una buena visión y poder hacer uso de la artillería de hallistae (A. Johnson, 1983, 72). Este mismo autor plantea algunas dificultades para la sujección de éstas en los ángulos redondeados (A. Johnson, id.).

En las murallas pétreas la disposición de las torres debía ser similar. Desde mediados del II o principios del III, junto a las cuadrangulares aparecen las torres redondas y semicirculares, muy apropiadas para las esquinas oblongas (A. Johnson, 1983, 73 y 92-93).

Algunos recintos constan de otros sistemas de refuerzo defensivo, el llamado titulum, sección de agger o muro desplazado delante de la puerta para protegerla, habitualmente acompañado de foso, y la clavícula o curvatura de un lado del agger cerca de la puerta para crear un pasaje defendido (A. Johnson, 1983, 50 y Wilson, 1980, 11). En nuestro país tenemos varios ejemplos del primer tipo en Almazán, Renieblas y Peña Redonda.

El último elemento con carácter defensivo son las puertas. Pueden ser cuatro o seis, dispuestas según los modelos teóricos establecidos por las fuentes clásicas. Están flanqueadas por torres cuadrangulares o rectangulares con el paseo de ronda entre ellas protegido mediante un parapeto y habitaciones para defensa en su interior. Suelen edificarse levemente retranqueadas respecto a la muralla, y sobresalen de 2,5 a 3 metros por encima de los lienzos (A. Johnson, 1983, 77-78). No difieren mucho sean de madera o piedra. Estas últimas pueden tener dos pisos de alto, tejados planos o inclinados, almenas en los parapetos, ventanas o aspilleras. Desde mediados del II o principios del III las torres de flanqueo comienzan a hacerse semicirculares (S. Johnson, 1983, 24).

Como ya hemos explicado, estos elementos no aparecen simultáneamente en el tiempo, ni existe una evolución perfectamente lineal entre los campamentos de madera y piedra. Las circunstancias concretas deben ser determinantes a la hora de escoger una u otra morfología y sis- 
tema defensivo para un campamento. En época republicana conocemos ejemplos de campamentos de piedra. Por supuesto que se produce una evolución que se puede documentar en los yacimientos ingleses y alemanes. Todavía en época augústea se dan recintos poligonales y de madera (Vetera, Novaesium). Al final del reinado de este emperador y durante el de su sucesor la regularización se hace más evidente, para culminar con la petrificación según un esquema bastante fijo durante el reinado de Claudio-Neron en Alemania (Jones, 1975, 14-18). Johnson retrasa este proceso en Renania hasta el gobierno de los Flavios, cuando tiene lugar la reedificación de muchos asentamientos militares, y restringe su campo de actuación a los campamentos legionarios, mientras los auxiliares y fuertes siguen siendo de madera (A. Johnson, 1983, 250).

En Gran Bretaña el proceso comienza más tarde. De la época de la conquista se conservan algunos recintos cuadrangulares, realizados en madera, tales como Hod Hill en Dorset. El principal cambio tiene lugar en el siglo II, con la introducción de la piedra como elemento constructivo (Wilson, 1980, 41). Esta transformación obedece a los mismos motivos que la sucedida en el limes renano algunas décadas antes: el establecimiento de una política de posiciones defensivas, consolidadas y estables, de centros de control del territorio más que de sometimiento del mismo. Durante el siglo siguiente el tipo parece no cambiar, a juzgar por lo que sabemos del Muro de Adriano (Breeze-Dobson, 1969).

Las transformaciones de los recintos militares a partir del siglo III y sobre todo durante el IV están bien ilustradas en la obra de S. Johnson (S. Johnson, 1983). El cambio principal será el abandono de la planta regular allí donde interese (S. Johnson, 1983, 27-29), la aparición de las torres redondeadas (S. Johnson, 1983, 24), y posiblemente, la desaparición de los fosos en algunos de ellos (Grenier, 1931, 403 y ss.). En conjunto puede hablarse de un proceso de refortificación y un desarrollo de las defensas.

Aparte de los trabajos ya mencionados referidos a Gran Bretaña presentamos aquí otros de interés (Robertson, 1979; Breeze, a1982; Hanson Y Maxwell, 1983; Lander, 1984; Crickmore, 1984, Davison, 1989).

La bibliografía alemana es algo más antigua. Entre los estudios más recientes destacamos los de Petrikovits (Petrikovits, 1971) y A. Johnson (Johnson, 1987), que recopila la casi totalidad de trabajos alemanes y británicos. En los últimos años la investigación en la región danubiana ha avanzado significativamente. Merece la pena mencionar la serie de publicaciones agrupada bajo el título común Der Römische Limes in Österreich. Entre ellas el catálogo de campamentos de Noricum y Panonia realizado por Genser (Genser, 1986), resulta sumamente útil. Asimismo Kandler y Vetters (Kandler y Vetters, 1986) y Visy (Visy, 1988), así como Cataniciu (Cataniciu, 1981) y Scorpan (Scorpan, 1980) para Dacia, resultan de consulta obligada para conocer el estado de la cuestión en Europa Central.

\section{Recintos castrenses en la historiografía española}

La investigación sobre asentamientos militares romanos en España ha pasado por varias fases a lo largo de aproximadamente cien años, que coinciden con la orientación científica particular de cada momento y con la presencia de figuras aisladas, que resultan trascendentales. Nos referimos, por supuesto, al caso de Schulten. El interés por determinadas cuestiones suele extenderse a lo largo de varias décadas, mientras aparecen puntualmente otros temas nuevos, pero no ha existido una continuidad en el estudio de los campamentos. 
He recogido y estudiado casi doscientos trabajos. De ellos algo menos de la mitad se dedican específicamente a recintos castrenses, mientras que el resto contiene referencias aisladas a este tipo de yacimientos. Un nutrido grupo, cuya finalidad es determinar la situación de los campamentos citados por las fuentes antiguas, se enmarca más en el ámbito histórico que en el arqueológico. Otro conjunto bien definido de trabajos plantea la cuestión de las fortificaciones urbanas bajoimperiales, bastante relacionado con cuestiones castrenses.

Hacia finales del siglo pasado tenemos algunos trabajos dispersos, que no siguen un criterio arqueológico, sino histórico. Se utilizan las fuentes como criterio de localización geográfica de yacimientos, sin comprobarlo seriamente sobre el terreno. Corresponde a la época de los primeros trabajos exploratorios de crítica textual. Los campamentos romanos identificados por De los Ríos y Ríos en Juliobriga (De los Ríos y Ríos, 1889), y por Fernández Guerra en Cáceres (Fernández Guerra, 1889) constituyen los primeros recogidos en la investigación moderna. Son obras sin bibliografía, que fuerzan la aplicación de las fuentes sobre el terreno, y carecen de toda fiabilidad.

En la segunda mitad de la primera década del siglo XX tiene lugar un gran despegue en los estudios sobre recintos militares castrenses, proceso determinado por la figura de Schulten. Es un interés centrado en los campamentos de Numancia, aunque más tarde se extienda hacia otros yacimientos. Schulten nunca llegó a crear un grupo de investigadores en torno suyo, sin duda por las especiales circunstancias que rodearon su trabajo desde el principio. Era un erudito ex-

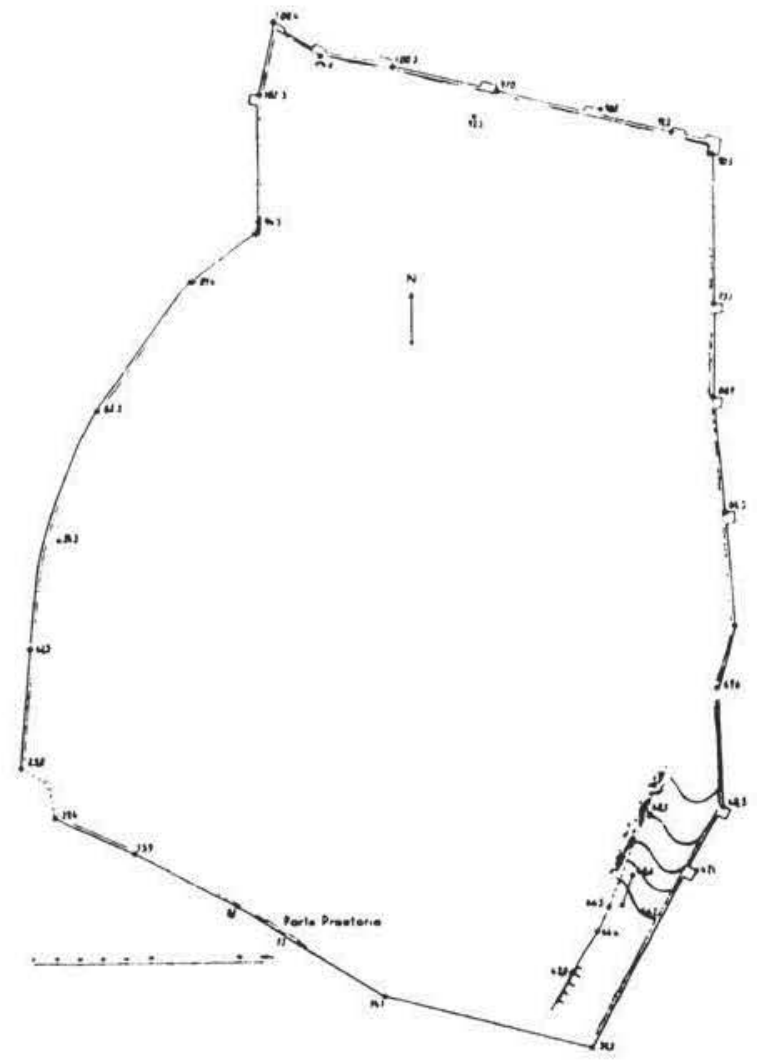

Figura 2.-Planta del campamento de Almenara, Valencia (Schulten, 1933). 
tranjero, muy bien visto por las autoridades políticas y culturales, que se sirvió de sus buenas relaciones para excavar allí donde deseaba, pero que nunca colaboró con otros estudiosos españoles. Esta postura encerraba sin duda algún desprecio hacia el panorama científico español. Por otro lado, no era arqueólogo, sino un buen estudioso de las fuentes antiguas y sólo esporádicamente trabajó con investigadores de este tipo (siempre alemanes) en su equipo. Tampoco hay que atribuir a Schulten toda la responsabilidad en el escaso eco que tuvieron sus trabajos dentro de nuestro país. Los historiadores y arqueólogos españoles centraban su interés en otras cuestiones, relacionadas más con el patriotismo y con un criterio coleccionista. No interesaba la investigación material sobre asentamientos concretos. La actitud de Schulten provocó además un rechazo tajante hacia su persona y sus teorías. Su obra, escrita en alemán y rápidamente traducida al francés e italiano, tuvo mucha repercusión fuera de nuestras fronteras, pero pasó bastante desapercibida en nuestro país, donde ni siquiera fue traducida, o lo fue bastante tarde. Un problema que complica el acercamiento a la obra del investigador alemán es la publicación de los mismos trabajos en distintos años y en idiomas y revistas diferentes.

Schulten nunca pretendió, en un principio, dedicar varios años de su carrera al estudio castrense. Tras sus primeras excavaciones en la ciudad de Numancia, su objetivo inicial, y a la vista del rechazo que mostraban los investigadores españoles a que un extranjero excavara en la ciudad arevaca, decidió dedicarse a los campamentos que establecieron los romanos para el asedio y conquista de la misma. Su éxito le llevó a ocuparse posteriormente de todos los testimonios de este tipo de los que tuviera noticia.

La producción de Schulten se extiende desde 1907 hasta 1943, fecha que hemos elegido como límite para este período, si bien sus trabajos se concentran en dos momentos muy claros: entre 1907 y 1918, con sus trabajos sobre los campamentos de Escipión en torno a Numancia (Schulten, 1907, 1908, 1913, 1914, 1918), y los campamentos de Renieblas (Schulten 1909, 1911, 1912, 1913, 1914, 1918); la década 1926-1935, durante la que se dedica a recopilar otros recintos: Almazán, Alpanseque, Aguilar, Rosinos de Vidriales y Almenara (Schulten 1927, 1933). Excava en Cáceres el Viejo (Schulten 1926, 1928 b, 1930, 1931 b, 1932), en colaboración con Paulsen (Paulsen 1928, 1930, 1932). Se publican en Alemania sus grandes compendios sobre los campamentos de Escipión en Numancia (Schulten, 1927 b), de Renieblas (Schulten, 1929) y la propia ciudad indígena (Schulten, 1931). También sus obras de conjunto sobre la historia de Numancia en alemán (Schulten, 1933 b) y sobre campamentos en España, simultáneamente en español y alemán (Schulten, 1928). De este período son también sus teorías sobre la muralla de Tarraco (Schulten, 1933 c).

A partir de 1935 prácticamente abandona sus estudios sobre campamentos, aunque en distintas publicaciones repite sus teorías. Es el momento de las grandes recopilaciones de fuentes referidas a España, las Fontes Hispaniae Antiquae (Schulten, 1935, 1937, 1940), y su trabajo sobre las Guerras Cántabras, donde plantea algunas cuestiones sobre campamentos augústeos que tendrán bastante eco (Schulten, 1943). A partir de esta fecha no vuelve a publicar sobre esta cuestión.

Las obras de Schulten se caracterizan por su conocimiento de las fuentes escritas, acompañado de una carencia de referencias a investigadores contemporáneos. Buena calidad de los mapas y reconstrucciones de plantas y alzados de defensas. En este sentido resulta bastante completo y avanzado. Realiza identificaciones históricas muy aventuradas, sin pruebas estratigráficas suficientes. 
Durante este período de más de treinta años, iluminado por el erudito alemán, existen además algunas figuras individuales con interés puntual. Es el caso de Giménez Soler (G. Soler, 1921) y Gómez Santacruz (G. Santacruz, 1914, 1935), encarnizados enemigos de las teorías de Schulten. Surgen las primeras publicaciones sobre las Guerras Cántabras (Magie, 1920 y Syme, 1934), más tarde continuadas por el mismo Schulten en 1943, las murallas de Tarragona (Rovira Virgili, 1922; Bosch Gimpera, 1926; Fick, 1933; Puig I Cadafalch, 1934) y Lugo (Melida, 1921). Mención especial merecen dos figuras: Richmond, que publica en 1931 el primer estudio sobre las fortificaciones bajoimperiales, y que fue poco conocido en España hasta hace pocos años. Se le considera el punto de partida de una cuestión muy actual; Taracena, el único investigador que sigue en cierta manera los pasos de Schulten en su interés por los recintos militares sorianos (Taracena, 1939, 1941, 1947).

Entre 1936 y mediados de los años cuarenta se produce un hiato en la producción bibliográfica, debido a la guerra civil y a los años de posguerra, que supusieron el extrañamiento de muchos estudiosos y la retirada de los investigadores extranjeros. Además, como ya comentamos, Schulten abandona el tema castrense. Hasta finales de los años 60 no reaparece el interés campamental propiamente dicho en el panorama científico español.

Existen pocos trabajos desde 1945 a 1955, sin duda como continuación de la época anterior. Como hecho más destacado podemos hablar del comienzo de las excavaciones sistemáticas en las ciudades de Ampurias y Tarraco, objeto de atención continuada hasta nuestros días (Almagro, 1945; García y Bellido, 1945; Almagro, 1947; Serra Vilaro, 1949; Almagro, 1951; Martínez Santa-Olalla, 1952; Lamboglia, 1955). Aunque los estudios se enfocan preferentemente hacia su carácter urbano, las publicaciones proporcionan algunos datos de interés acerca de su origen.

Desde mediados de los años cincuenta comienza la investigación arqueológica moderna y científica. Conviven varias tendencias: por un lado continuidad de los trabajos referidos a las ciudades de Ampurias y Tarraco (Lamboglia, 1958; Almagro y Lamboglia, 1959; Beltrán, 1965; Beltrán, 1967); por otro lado, aparece una potente corriente de estudios históricos basados en las fuentes, que se desarrollará mucho durante los años posteriores (García y Bellido, 1961, 1966; González Echegaray, 1966) y tendrá interés para la localización de recintos campamentales; junto a las dos corrientes anteriores, y sin duda muy unido en su nacimiento a la cuestión de las supuestas invasiones del siglo III en Hispania, aparece el tema de las fortificaciones urbanas tardorromanas, investigado de cerca por Balil (Balil, 1956, 1960, 1963, 1964). Se publican también algunas noticias dispersas procedentes de las excavaciones y prospecciones arqueológicas, que comienzan a ser frecuentes: Iruña (Nieto Gallo, 1958), Pamplona (Mezquiriz, 1958), Lugo (Vázquez Seijas, 1955), Astorga (Luengo, 1955, 1961) y Castrocalbón (Loewinsohn, 1963).

Son trabajos con una bibliografía bastante completa, aunque esta cuestión depende de cada autor. Suelen llevar dibujos de las piezas más importantes, así como planos más o menos ajustados a la realidad. En algunos de ellos la excavación o descripción arqueológica está acompañada por una identificación histórica, más o menos hipotética o justificada.

Desde finales de los años 60 y durante toda la década siguiente se produce una reactivación de la investigación arqueológica sobre ciudades amuralladas bajoimperiales, siguiendo una tendencia iniciada fuera de nuestras fronteras (Petrikovits, 1971). Dentro de esta corriente se inscribe el trabajo de Elorza sobre Iruña (Elorza, 1972). Muy importante resulta la celebración 
de varios congresos que estudian el tema de las fortificaciones. En 1970 tiene lugar el monográfico sobre León con motivo del XIX aniversario del asentamiento de la Legio VII, donde se presentan varios artículos sobre el tema (Syme, 1970; García y Bellido, 1970; Balil, 1970; Forni, 1970). Pocos años después, en 1976 se celebra un Symposium sobre ciudades de fundación augústea, donde se traen a colocación los trazados amurallados y el origen de Astorga (Mañanes, 1976; Pastor Muñoz, 1976), Lugo (Arias Vilas, 1976) y Pamplona (Mezquiriz, 1976). En 1977 se celebra el Bimilenario de Lugo (Le Roux, 1977), precedido de varios trabajos sobre su recinto murado (Arias Vilas, 1976, 1976 b). La importancia de estas reuniones, muy frecuentes a partir de este momento, reside en que plantear el origen y la misma existencia de varios recintos fortificados que bien pudieran ser antiguos campamentos, y orientan a los investigadores en una determinada dirección.

Mucho menos trascendente resulta el Coloquio Conmemorativo del XXI Centenario de la Conquista de Numancia, porque adquiere un carácter más histórico que arqueológico (Calama y Rosellón, 1972; Beltrán Martínez, 1972; Pericot, 1972).

Durante este período continúa la investigación acerca de los temas surgidos en momentos anteriores. Se sigue excavando en las ciudades costeras catalanas (Balil, 1969; Sanmartí, 1973; Hauschild, 1973-4; Ripoll Perello i Llongueras, 1974; Martínez Gázquez, 1974; Lamboglia, 1974; Hauschild, 1975; Hauschild, 1976-7; Ripoll Perello, 1978). Se desarrolla un interés creciente por los temas militares derivados de la presencia y conquista romana, en principio ligado a las investigaciones de los historiadores, pero que cada vez más se relaciona con los restos materiales y la arqueología (Roldán, 1972-3, 1974, 1976; González Echegaray, 1975, 1977; García y Bellido, 1976; Jones, 1976). Coincide con una tendencia general en los estudios de esta época, orientados hacia el conocimiento del territorio y las formas de asentamiento e implantación en el mismo. Progresivamente aparece más clara la importancia del ejército en la articulación del espacio humano en las regiones más septentrionales de la Península.

Muy relacionado con la corriente anterior, se asiste a un florecimiento creciente de estudios dedicados específicamente a campamentos propiamente dichos. Son los casos de Almazán (Gamer y Ortego, 1969), Sasamón (Abasolo, 1975) Cáceres el Viejo (Beltrán, 1973-74, 1976) y Rosinos de Vidriales (Martín Valls y Delibes de Castro, 1973-82, 1975).

Llegamos así a la última fase de la investigación, que arranca de finales de los 70 y continúa hasta nuestros días. Se caracteriza por una continuidad de los intereses de la etapa anterior, si bien mediante trabajos normalmente más serios y rigurosos científicamente hablando. Se sigue trabajando en Tarraco (Hauschild, 1979; Neuebauer, 1980; Papiol, 1980; Hauschild, 1982; Pena, 1984; Dupre, 1988), Ampurias (Aquilue y V.V.A.A., 1984), y Astorga (Mañanes, 1982 y 1983). Se han reconocido nuevos recintos como Aquis Querquennis (Rodríguez Colmenero, 1980) y A. Cidadela de Sobrado dos Monxes (Caamaño Gesto, 1984), a veces con una finalidad definida completamente inédita en España. Es el caso de Valdemeda (Sánchez Palencia, 1986 y 1988). Ulbert ha excavado concienzudamente el de Cáceres el Viejo (Ulbert, 1984) y Sánchez-La Fuente reexplora Aguilar de Anguita (Sánchez-La Fuente, 1979).

Persiste el estudio sobre implantación militar (Roldán, 1983 y 1984) e identificación de nuevos recintos castrenses como Herrera de Pisuerga (Pérez González, 1981, 1986, 1986 b y 1989). La recopilación de Le Roux sobre los estudios dedicados a temas militares resulta de gran utilidad (Le Roux, 1979), así como su trabajo monográfico sobre el ejército romano en Hispania (Le Roux, 1982). 
En la actualidad todavía no hay trabajos específicos de fortificaciones campamentales, aunque sí de ciudades bajoimperiales. El tema no interesa excesivamente y, por otro lado, no se conservan demasiados datos. Se busca más la relación de la presencia militar con el territorio y sus interrelaciones. El objetivo principal sigue siendo dónde se localizan y el porqué, antes que su descripción, pero quizá esta fase sea necesaria debido al retraso en el estudio respecto a otros países. La metodología arqueológica y la publicación suele ser bastante adecuada.

En resumen, podemos decir que no ha existido una investigación continuada de campamentos romanos en España, salvo algunos casos concretos como Ampurias y Tarraco. Pero incluso en estos se ha debido a su carácter urbano, no a su origen castrense. El resto de los recintos militares ha pasado por momentos de atención, como Numancia, o son conocidos por referencias esporádicas. Gran parte de los datos referidos a campamentos provienen de estudios sobre ciudades fortificadas y temas como la presencia militar, las Guerras Cántabras y las fuentes. En los últimos años muchos puntos oscuros comienzan a aclararse mediante la excavación sistemática y planificada de determinados yacimientos.

\section{Periodización}

Para estudiar las fortificaciones castrenses españolas voy a agruparlas cronológicamente por períodos más o menos definidos por las fuentes y la opinión de los investigadores. Comenzaré por los campamentos de época republicana, distinguiendo los períodos de actividad constructiva, para después analizar los datos referentes a sus recintos defensivos. Un segundo bloque temático lo constituyen los campamentos imperiales, tanto los que no han tenido otra función, como los que después se han convertido en ciudades y han sido fortificados. El tercer grupo comprende las ciudades fortificadas bajoimperiales, de discutible filiación militar. Quiero dejar claro que la cronología y la identificación utilizada en este trabajo son las apuntada por los autores que han clasificado los distintos recintos, recogiendo las distintas teorías en el caso que las hubiera, pero sin entrar a juzgar la veracidad de las mismas.

Los autores clásicos que más noticias aportan sobre el tema son: Polibio (Historias, Libros III y X), Tito Livio (Ab Urbe Condita, libros XXI, XXII y XXXIV; Periochae, 55), Apiano (Iberia, 45-50, 67-69, 76, 80, 83, 85, 89-92), Frontino (Strategemata, libro I), Plutarco (Vitae... Tiberius Graccus), Salustio (Historiae, II). Las referencias a las campañas de las Guerras Cántabras se encuentran en Floro (Epitome Gestae Romanae, libros I y II), Orosio (Adversus paganos, 5) y Estrabon (Iberia, III). La Noticia Dignitatum constituye la única fuente bajoimperial.

Las citas literarias suelen ser muy breves y concisas ya que no es un tema especialmente atrayente para los historiadores antiguos. Las más frecuentes son las referencias a campamentos establecidos durante un largo período de tiempo, como el caso de los hiberna. Pero incluso en estos casos las fuentes no pasan de indicar la distancia que les separa de determinadas poblaciones. Se concentran lógicamente en los momentos más álgidos de las guerras de conquista. Asimismo su distribución geográfica está íntimamente relacionada con las incidencias de la lucha contra los indígenas y la penetración romana hacia el interior de la Península. 


\subsection{CAMPAMENTOS ROMANOS DE ÉPOCA REPUBLICANA}

\subsubsection{Los primeros asentamientos romanos (217-195)}

- Tarraco

Las primeras citas a pretorios o campamentos romanos corresponden a la costa mediterránea. El único recinto testimoniado por la arqueología, además de las fuentes es Tarraco, campamento de invierno y base naval romana, tal como indican Polibio (III, 76, 12; III, 95, 4; X, 40,12 ) y Tito Livio (XXI, 61; XXII, 19, y XXII, 22). Constituía el punto de llegada de las flotas itálicas y un centro de aprovisionamiento seguro.

Sabemos muy poco del primitivo asentamiento romano en la colina de Tarragona. Si no fuera por las citas textuales podríamos dudar de que la ciudad fue alguna vez un establecimiento militar. Los datos más útiles para nosotros son los que ofrece el estudio de la muralla. Basándose en la existencia de un zócalo de aparejo ciclópeo y una parte superior de opus cuadratum, los investigadores le han atribuido origenes diversos: prerromano (Bosch Gimpera, 1926; Puig i Cadafalch, 1934, 15-6; Martínez Santa-Olalla, 1952; Beltrán, 1965 y Beltrán, 1967, 155), cartaginés (García y Bellido, 1945, 151), romano (Rovira Virgili, 1922, 170), bajoimperial (Fick, 1932), e incluso de "técnica etrusca», mal definida cronológicamente (Schulten, 1933; 148-9). Serra Vilaro estudia por primera vez el aparejo interno de la muralla y descubre que consiste en dos paredes paralelas separadas por tres metros y medio, y rellenas con piedras y adobe. Este relleno se da tanto en el sector de la muralla con aparejo regular, como en el zócalo ciclópeo. Encuentra materiales del siglo III a. C., lo que unido a los datos anteriores le lleva a pensar a una datación única de la muralla en época de los Escipiones (Serra Vilaro, 1949, 221-236). No aclara el carácter civil o militar de este primer enclave romano en la Península.

El primer investigador que da una opinión sobre esta cuestión es Lamboglia. Confirma la datación de las cerámicas halladas por Serra, pero asegura que la muralla no corresponde al campamento, sino al núcleo civil de la capital provincial (Lamboglia, 1958, 164). El problema principal es que no menciona las razones que le llevan a esta conclusión. AL igual que las que le llevan a modificar totalmente su opinión unos años más tarde, donde la define como "colonia e stazione militare del tempo della conquista romana" (Lamboglia, 1974, 397). En la misma obra, algo más adelante, señala el carácter romano antiguo de la muralla, su inexcusable importancia militar y su utilización para cuarteles de invierno del 218-217. Se pregunta si el motivo de su trazado irregular, y de que Escipión no le diera las dimensiones y la fisonomía de un campamento no estaría en la necesidad de incluir un núcleo indígena preexistente (Lamboglia, 1974, 400), como también parece deducirse de la presencia de cerámica griega e ibérica junto con la campana (Lamboglia, 1974, 398-9). Esta idea parece confirmarse en trabajos posteriores.

Los trabajos de Balil (Balil, 1969) y, sobre todo, de Hauschild suponen la continuación de las investigaciones de Serra Vilaro y Lamboglia. Hauschild recoge en sus primeros trabajos la teoría de que la erección de la muralla se produce con la llegada de los romanos (Hauschild, 1973-4, 32). En 1976-7 estudia la Torre de Minerva, y en 1979 (en catalán en 1983) publica el final de su investigación sobre esa torre y el Baluarte de Santa Bárbara. Llega a la conclu- 
sión de que existen dos fases en la construcción del recinto amurallado. De la primera fase, que corresponde a finales del III a. C., se conservan tres torres (Minerva, Cabiscol y Arzobispo) separadas por tres lienzos de muro. Esta construcción tendría 4,5 metros de ancho y no

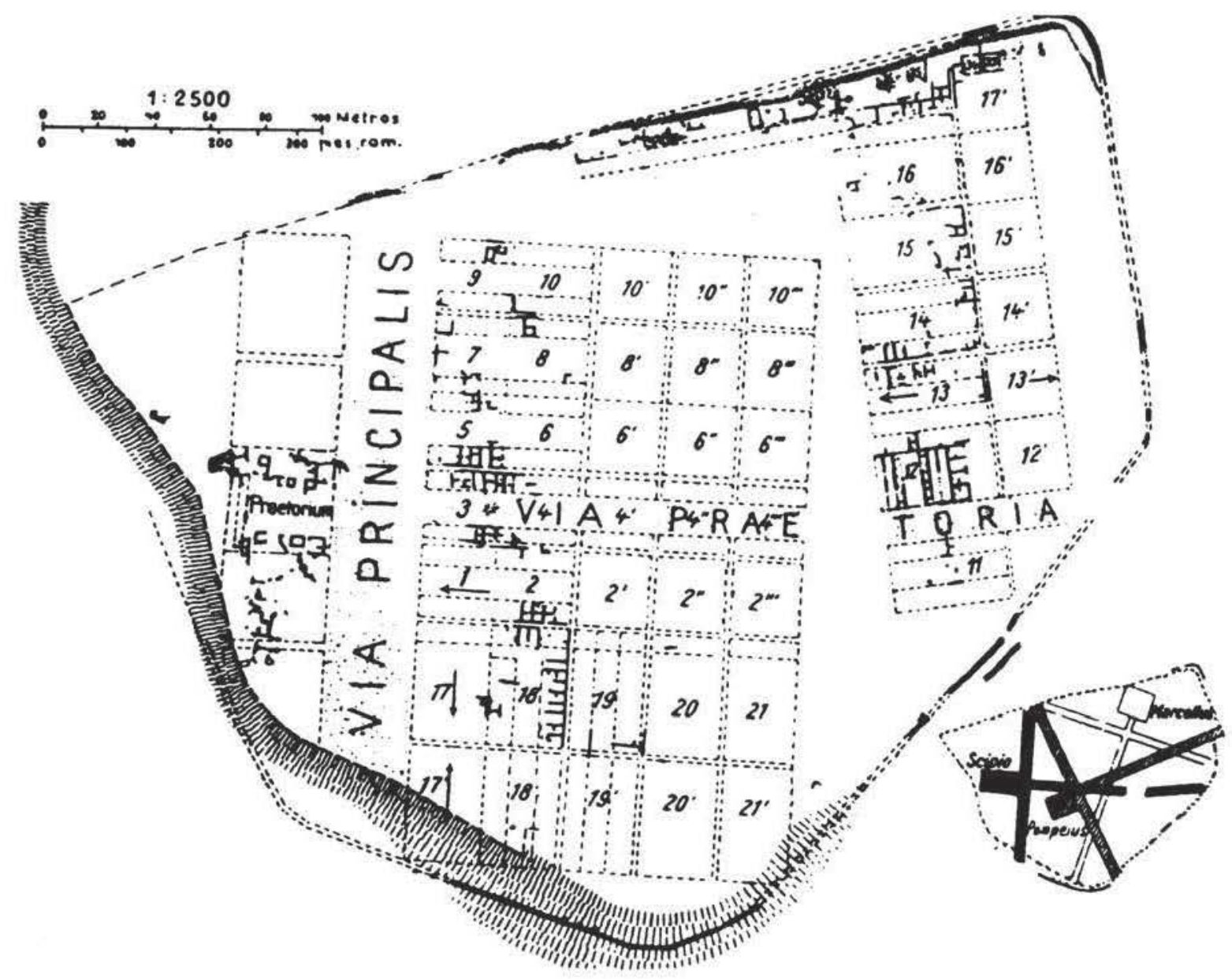

Figura 3.-Planta del campamento de Castillejo, Numancia, Soria (Schulten, 1945).

más de 6 de alto (Hauschild, 1983, 176 y 156). El zócalo megalítico sería una técnica prerromana pero utilizada durante la época romana (Hauschild, 1976-7, 69). Sobre éste se dispone un opus reticulatum con sillares almohadillados y bien escuadrados, colocados a soga y tizón (Hauschild, 1976-6, 53). Las torres son rectangulares, también con las hiladas inferiores de grandes bloques de piedra, separadas por tramos de muralla con medidas irregulares que conservan poternas, en número de seis, junto a las torres y bien protegidas por éstas (Hauschild, 1976-7, 50 y 72-3). En la torre de la Minerva existía una cámara superior con aspilleras (Hauschild, 1983, 176).

Durante una segunda fase, fechada por el autor a principios del siglo II a. C ., la muralla se amplía hasta 6 metros de achura y 12 de alzado, adosando un nuevo paramento en el interior con un zócalo megalítico más bajo (Hauschild, 1983, 176). 
La muralla se edifica posiblemente entre el 218 y el 204, ya que en el 197 la capital se traslada a Cartago-Nova (Hauschild, 1976-7, 67-68). Sería un recinto militar que acogería durante la guerra contra Cartago a la mayor parte de los 70.000 legionarios y 80.000 aliados (Hauschild, 1983, 180).

Los últimos trabajos publicados confirman la existencia de un Praesidium desde el punto de vista tanto de las fuentes (Pena Gimeno, 1984, 77-78), como de la arqueología (Papiol Moline, 1980; Dupre, 1988). Neuebauer ha creído ver una explicación al uso de aparejo ciclópeo en la talla in situ de grandes bloques de piedra que estuvieran en la colina. Cuando se terminaron, los canteros recurrirían a piedras talladas regularmente de las canteras cercanas (Neuebauer, 1980, 111). No deja de ser una hipótesis interesante pero indemostrable.

\section{- Almenara (Valencia)}

La existencia de un recinto de tipo militar 9 kilómetros al norte de Sagunto, que coincidía con los datos proporcionados por Polibio (III, 97, 6), es mencionada por primera vez en 1927 (Schulten, 1927, 232-235), y estudiada por este autor en publicaciones ulteriores (Schulten, 1928,36 y Schulten, 1933, 522-527). Constituye un asentamiento irregular, construido en forma trapezoidal mediante varios tramos rectos de muro de 1,5 metros de ancho. El eje máximo es de 470 metros y la extensión de 9,4 hectáreas. Presenta 16 torres cuadrangulares a lo largo del perímetro. La Porta Praetoria se halla al sudoeste y está flanqueada por dos torres (Schulten, 1933, 525). Siguiendo a las fuentes debió ser edificado por los Escipiones en la campaña del 217, cuando avanzaban sobre Sagunto, después de pasar el Ebro (Schulten, 1928, 36). No ha vuelto a ser explorado desde principios de los años treinta, con lo que su autenticidad es discutible.

\subsubsection{La campaña de Caton del 195}

\section{- Ampurias}

A pesar de que el desembarco romano en la Península se produce en Ampurias (Polibio, III, 76, 1), no se mencionan campamentos cercanos a esta ciudad hasta la época de Caton. Tres citas corroboran la existencia de uno o varios campamentos establecidos por el cónsul junto a la colonia griega. Livio, en su libro XXIV, 11, ofrece la escueta noticia de la construcción de un recinto militar en Ampurias. Algo más abajo (XXXIV, 13) asegura que es un campamento de invierno y se encuentra a tres millas de dicha población. Frontino corrobora la noticia $(I, 2,5)$. Desde un principio la arqueología ha intentado situarle con éxito. Puig i Cadafalch ya hacía notar en 1934 que la planta cuadrangular de la ciudad romana recordaba un agger militar (Puig i Cadafalch, 1934, 65), pero los investigadores posteriores pensaron que el campamento habría estado extramuros de la ciudad. Se localiza alternativamente en La Serrilla al oeste del núcleo urbano (Schulten, 1935, 183), en la llanura de l'Armentera, oculto por alguna avenida del río Fluviá, en las playas de Montgó, o en la zona de D'Albons (Almagro Basch, 1951, 72-73). Ripoll (Ripoll Perelló, 1978, 45) piensa incluso que los restos de un 
muro de aspecto arcaico aparecido en la Bahía de Riells pudieron ser restos del campamento (Ripoll y Llongueras Campaña, 1974).

Almagro, en sus excavaciones de la muralla romana no halla material anterior al siglo II a. C., que pueda ser atribuido a un presidio (Almagro, 1945, 59-63, y 1947, 187). Sanmartí es el primero en afirmar que el campamento debió instalarse en la parte alta de la colina, dominando la ciudad griega y la bahía (Sanmartí, 1973, 117-118), al no encontrar restos de la ciudad indígena en tal lugar. Martínez Gazquez llega a la misma conclusión a través de la crítica textual (Martínez Gazquez, 1974, 58 y 161).

En sus excavaciones publicadas en 1984, Aquilue et alii encuentran la clave para la localización del campamento. Interpretan un muro que forma un ángulo, construido en aparejo ciclópeo y ya publicado por memorias anteriores (Lamboglia, 1955, 202-203; Almagro y Lamboglia, 1959, 21-22) como parte del Praesidium catoniense (Aquilue y V.V.A.A., 1984, 36-41). Almagro y Lamboglia habían fechado esta construcción a principios del siglo II a. C., basándose en la datación de la cerámica campaniense, pero nunca lo asociaron a una función militar, sino a un edificio público (Almagro y Lamboglia, 1959, 21-22). El muro tiene una orientación norte-sur, y sólo se conserva la última hilada de piedras. Existen varias cisternas monumentales asociadas en el ángulo sureste (Aquilue y V.V.A.A., 1984, 42). Los investigadores concluyen afirmando que sería un establecimiento rectangular con carácter militar construido en el primer cuarto del siglo II a. C., posiblemente en época de Catón. Su desaparición coincidiría con el establecimiento de la ciudad romana de nueva planta en el tránsito entre los siglos II-I a. C. (Aquilue y V.V.A.A., 1984, 47). La dificultad para acpetar totalmente esta tésis reside en la práctica imposibilidad de comprobarla, dada la escasez de restos del pretorio conservados.

\section{- Aguilar de Anguita}

Al parecer fue descubierto en 1912 por Aguilera y Gamboa, que informa de su intención de realizar excavaciones (Aguilera y Gamboa, S/F). Estas se llevaron a cabo entre 1913 y 1915 y dejaron al descubierto toda la muralla (Aguilera y Gamboa, 1916, 83-85). Schulten lo recoge por primera vez en 1913 (Schulten, 1913, 31-32) y en publicaciones sucesivas (Schulten, $1927,198-200 ; 1928,36 ; 1929,191-5)$. Taracena lo cita entre los campamentos republicanos (Taracena, 1947, 28). Otros investigadores lo aluden de pasada (García y Bellido, 1976, 70-1 y Jones, 1975, 81). Recientemente ha sido descrito por Sánchez-La Fuente, que no ha realizado excavaciones (Sánchez-La Fuente, 1979).

El campamento se sitúa sobre un cerro amesetado, 20 kilómetros al este de Sigüenza y junto al camino natural que asciende por valle del Jalón hacia la Meseta. La planta es irregular y abarca 12,4 hectáreas (Schulten, 1928, 36). Las excavaciones descubrieron toda la muralla en sus dos caras (Schulten, 1927, 191), separadas por casi dos metros de anchura. Estaba jalonada con torres cuadradas dispuestas en su interior, con acceso por escaleras de piedra. Se excavaron cuatro puertas, dos de ellas dispuestas de forma desencajada, dejando un pasillo entre ellas (Aguilera y Gamboa, 1916, 83-85). Sánchez-La Fuente identifica la técnica de construcción de las puertas como indígena, a base de realizar desmontes al lienzo perpendicular (Sánchez-La Fuente, 1979, 78). 
En la actualidad el recinto murado resulta todavía visible. Las dos caras del muro y el relleno interior a base de guijarros pueden seguirse a lo largo de todo el perímetro. Las torres con sus escalones se aprecian bien, al igual que las puertas. Es uno de los escasos ejemplos que se conserva en buen estado.

Respecto a su datación cronológica Schulten planteó varias hipótesis de acuerdo con los textos. La más probable entre ellas era que fuera del tiempo de Catón, al regreso del cónsul de su expedición al Mediodía, cuando intenta la toma de Segontia y establece pretores en los campamentos (Schulten, 1929, 192). Para Sánchez-La Fuente el carácter temporal que se desprende de las fuentes no se corresponde con las dimensiones del campamento, su construcción en piedra y el grosor de los muros. Por otro lado, la distancia a Sigüenza no lo hace operativo en un ataque. Este investigador afirma que sería un campamento base desde donde se iniciarían hostilidades contra Segontia y los pueblos de los alrededores, muy numerosos, tal como confirman los restos (Sánchez-La Fuente, 1979, 80).

La imposibilidad de identificar los materiales depositados en la colección del Marqués de Cerralbo no permite una datación más aproximada.

\section{- Renieblas I y II}

También este campamento ha sido atribuido por Schulten a las campañas de Catón (Schulten, 1909, entre otros). Más adelante veremos la reconstrucción histórica y arqueológica de este asentamiento que fue reocupado cuatro veces.

\subsubsection{Campamentos de la guerra contra Numancia (154-133 a.C.)}

\section{- Campamentos de circumvalación de Numancia}

La fuente clásica principal es la Iberia de Apiano, especialmente sus capítulos 90-92: «No mucho después, habiendo (Escipión) instalado sus campamentos cerca de Numancia, puso uno a las órdenes de su hermano Máximo, el otro bajo su propio mando»... «Levantó siete castillos alrededor de la ciudad y empezó el asedio»... «dio orden de rodear la ciudad con un foso y una valla». Floro, en I, 34, 11 presenta una versión algo diferente, al reducir el número de campamentos a cuatro. El episodio se data en el 134-133 a. C., durante el asedio y asalto final a la ciudad arevaca. Schulten considera que los campamentos del procónsul Claudio Marcelo del año 152 (Apiano, 50), de Q. Pompeyo Aulo en el 141 (Apiano, 76) y Pompeyo en el 140 a. C. (Apiano, 48) corresponden, a juzgar por la distancia, al encontrado en el Cerro Castillejo (Schulten, 1927, 175 y 181; Schulten, 1937, 42).

Las investigaciones de Schulten sobre el particular constituyen el punto de arranque de su interés por los recintos militares. El autor presentó sus resultados en varias publicacions que ya he citado, siendo la primera en 1907-8 (Schulten, 1907 y 1908), aunque yo seguiré la edición francesa de 1908-10. Se encuentran entre los mejor conocidos en cuanto a defensas.

El historiador alemán descubrió siete recintos en torno a Numancia, a lo largo de tres campañas de excavación (1906-1908). Lo primero que llamó su atención fue el hecho de que tu- 


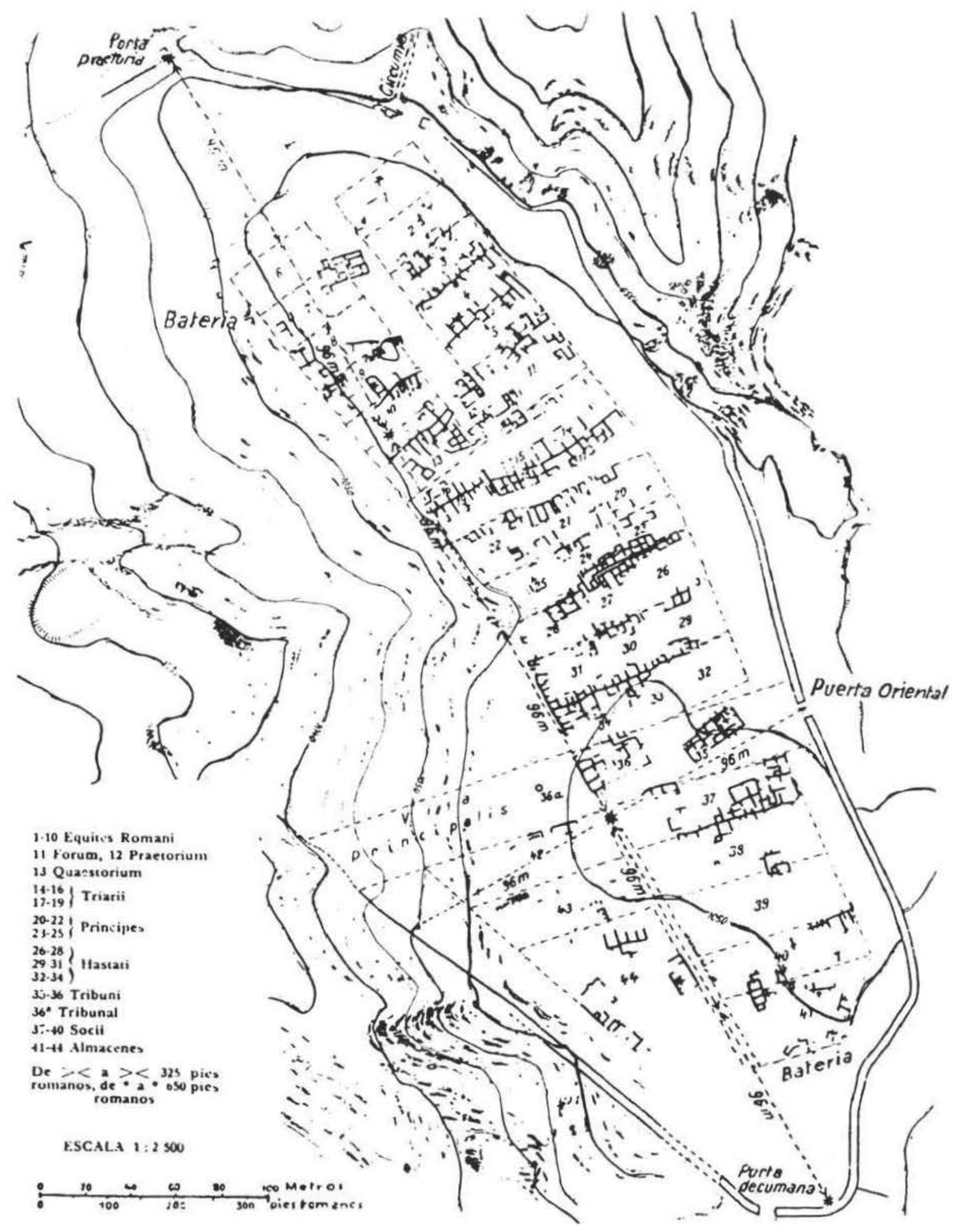

Figura 4.- Planta del campamento de Peña Redonda, Numancia, Soria (Schulten, 1945). 
vieran la piedra como material de construcción, al igual que las construcciones imperiales (Schulten, 1908, 129). El campamento principal, asiento para Schulten del propio Escipión, es el llamado Castillejo, al norte de la ciudad arevaca. Comenzó a excavarlo en 1907, continuando al año siguiente. Es un gran campamento, de 6 hectáreas, muy fácil de defender ya que existe un único acceso practicable al Norte (Schulten, 1908, 144). Aún así se dota de fortificaciones muy fuertes. El lado norte presenta una muralla de 5,50 metros de anchura, construida con dos muros paralelos de un metro rellenos de guijarros, y una doble fosa de 10,5 metros de ancho. En los lados este y sur la muralla presenta entre 1,5 y 2 metros de anchura realizada en piedra calcárea bien tallada. En el lado oeste no hay ni muralla ni foso (Schulten, 1908, 145). La puerta decumana tenía 8 metros de ancho y estaba flanqueada por dos torres de sillares bien escuadrados. El espacio anterior de la puerta está dividido en dos partes por un muro (Schulten, 1908, 145-6).

Tras las excavaciones del año 1908, Schulten llega a la conclusión de que existen tres campamentos superpuestos, basándose en la diferente orientación de las casamatas. El campamento más antiguo es atribuido al cónsul Marcelo, que inverna en Numancia el 152-1. Parece que la muralla sur corresponde a este campamento (Schulten, 1910, 248 y 254-6; Schulten, 1927, 175-181); el segundo sería el de Escipión, al que pertenecería el gran muro norte (Schulten, 1910, 249-50; Schulten, 1927, 188-216); el último carece de fortificaciones apreciables y se data en época de Pompeyo.

El siguiente en importancia era el de Peña Redonda, en una colina situada al Sur de Numancia, muy fuerte y con accesos escarpados. Presenta grandes dimensiones, 5 hectáreas (Schulten, 1908, 130). Las fortificaciones consisten en una muralla de dos muros paralelos de piedra calcárea rellenos con tierra, de 4 metros de anchura, y un foso poco profundo de 10 metros de anchura. La muralla no aparece en el talud. En el lado oeste se disponen aterrazamientos sujetos por grandes muros de piedra. Intervallum intramuros, de tres metros en su punto más estrecho, con casamatas para centinelas. La puerta pretoria muestra dos torres a los lados, con clavícula en el extremo derecho (Schulten, 1908, 130-132; Schulten, 1927, 100-2).

El recinto de Dehesilla se sitúa al oeste. Perímetro de 1.650 metros, que cubre una superficie de 16 hectáreas. Muralla de dos muros paralelos rellenos con piedras irregulares mediante el sistema de emplecton, de cuatro metros de anchura (Schulten, 1909, 16; Schulten, 1927, 226-228).

En los campamentos de Rasa, al sur, Valdevorrón, al este y Alto Real, al noroeste, también aparecieron restos de fortificaciones, pero en todo caso son de menor envergadura, están más deshechas y plantean mayores problemas de autenticidad.

El muro de circunvalación, que según Schulten unía estos campamentos, tenía una anchura de 4 metros en las elevaciones y 2,60 en los valles. Estaba construido con aparejo ciclópeo y poseía torres con habitaciones para los centinelas y las baterías (Schulten, 1909, 17-18).

El problema principal de las teorías de Schulten reside en la excesivamente imaginativa interpretación de muchas construcciones, a las que dio un sentido del que carecían y ahora resulta muy difícil de corregir, además de las dataciones arbitrarias, utilizando las fuentes como único argumento. Ya algunos autores censuraron este hecho (Giménez Soler, 1921; Gómez Santacruz, 1914, 91-100, y Gómez Santacruz, 1935, 51 y 54). La misma existencia de siete campamentos, que él creyó ver confirmada en las fuentes, está en discusión. Se hace necesaria 
una reexcavación sistemática para comprobar los datos del investigador alemán, a pesar de que en la situación actual de los yacimientos muchos datos se han debido perder definitivamente. Una parte de los mismos está abandonada, pero otros (por ejemplo, el Castillejo) son tierras de labor sujetas a numerosas agresiones humanas.

\section{- Los campamentos de Renieblas (Soria)}

Hallados en 1908 por Schulten en la Gran Atalaya de Renieblas, tras varias excavaciones preliminares. Se localizan a 6 kilómetros al este de Numancia. Su excavador cuenta que los muros se reconocían en gran parte a flor de tierra, lo que permitió levantar planos directamente. El campamento V, en la llanura, debió excavarse por completo (Schulten, 1914, 26, ed. alemana de 1913). Los trabajos se prolongaron durante cuatro años consecutivos, desde 1909 a $1912 \mathrm{y}$, aunque las primeras noticias sobre su existencia salieron a la luz en 1911 (Schulten, 1911), las descripciones más completas se encuentran en 1914 (Schulten, 1914, ed. alemana 1913), 1928 (Schulten, 1928, 35-6), 1929 (Schulten, 1929) y 1945 (Schulten, 1945, ed. alemana 1933).

Se descubrieron restos de cinco campamentos extendidos por toda la ladera de la colina. El campamento I tiene planta irregular y ocupa una superficie de 12 hectáreas. Sus defensas consisten en un muro de piedra de 2 a 2,5 metros de espesor jalonado por torres cuadrangulares (Schulten, 1929, 34). Se sabe poco más de sus características constructivas. Schulten atribuye su erección al cónsul Catón, en el año 195, sin más argumento que sus dimensiones, muy similares al de Aguilar de Anguita (fechado por él mismo en este momento), y el vacío de información en las fuentes entre Catón y las primeras campañas de Nobilior, al que atribuye el III (Schulten, 1929, 37-38).

El campamento II es datado en este mismo momento, aunque no explica el motivo de la construcción de dos campamentos sólidos en un mismo año y en el mismo lugar. De este recinto se conserva menos de la mitad del perímetro irregular de la muralla, que tiene una anchura de dos metros y torres adosadas (Schulten, 1929, 39-40).

El recinto número III es el más importante y sorprendente, a la par que el mejor conservado. Consta de imponentes murallas de 4 metros de anchura, que se ensanchan hasta alcanzar los 5 en algunos tramos, construidas mediante un aparejo irregular con grandes bloques de piedra calcárea de hasta 2 metros de largo por 1 de alto. Consisten en dos muros paralelos frontales rellenos de guijarros, siguiendo la técnica de emplecton. Se conservan 27 torres cuadradas a lo largo del perímetro con espesor y anchura variables, y dos semicirculares bastante grandes. Seis puertas, el número canónico, con un vano de 3 metros. La puerta decumana, la principalis dextra y la quintana sinistra no se conservan bien (Schulten, 1929, 50-59; Schulten, 1945, 70).

La importancia de este campamento reside en que se ajusta casi perfectamente a las normas polibianas, hecho excepcional dentro de los campamentos republicanos. Aunque su perímetro es algo irregular por su adaptación al terreno y la inclinación del mismo, la disposición interna y la organización del espacio para dos legiones responde con exactitud al esquema del historiador griego. Lo único que varía es la orientación del pretorio, afrontado hacia Numancia. Schulten atribuye el campamento al procónsul Nobilior, y lo considera un castra hiberna del 
año $153 \mathrm{a}$. C. Apiano recoge la construcción de un asentamiento militar «a veinticuatro estadios de Numancia», en el que invernó el cónsul Nobilior durante el año 153-2 a. C. (Iberia, 46-7). Nobilior tiene tiempo para construir un campamento estable, porque los arevacos no interfieren. El lugar fue escogido cuidadosamente, en la bifurcación de dos caminos hacia el Valle del Ebro, el que conduce a Bursao y Calagurris, y el de la Rioja (Schulten, 1914, 27-8; Schulten, 1945, 66-8, entre otros). Al año siguiente, el sucesor de Nobilior, Claudio Marcelo, vuelve a acampar a 5 estadios de Numancia (Apiano, Iberia, 50). La diferencia de distancias respecto a la ciudad arevaca existente entre el recinto de Nobilior y el de Marcelo ha llevado a Schulten a situar este último en el Cerro Castillejo, cuya proximidad a Numancia, un kilómetro, coincide con los datos de las fuentes (Schulten, 1927, 175).

Los campamentos IV y V son atribuidos a Pompeyo, a pesar del silencio de las fuentes. De nuevo el argumento de Schulten no es arqueológico, sino literario: los textos clásicos sólo mencionan operaciones militares durante las guerras sertorianas (Schulten, 1914, 28). Salustio (Historiae, I, 94) menciona que Pompeyo «Ordenó al legado Titurio que pasase el invierno en la Celtiberia con quince cohortes, a la cabeza de los aliados». El recinto número IV carece de construcciones interiores, pero está protegido por muros de piedra sin torres (Schulten, 1945, 251). Debió ser un campamento temporal del verano del 75 a. C. El V presenta murallas de 4 metros de anchura, con piedras trabadas con argamasa, y torres defensivas. Resulta muy similar a los campamentos imperiales, aunque éstos tienen las murallas compactadas mediante hormigón (Schulten, 1914, 30). Schulten considera que fue un campamento de invierno del año 75-74 (Schulten, 1914, 28-30; Schulten, 1929, 148-9; Schulten, 1945, 251-2).

La excavación de estos recintos militares ha seguido los mismo criterios que los campamentos en torno a Numancia, por lo que hacemos extensivas las observaciones. Las atribuciones históricas y cronológicas del investigador alemán han sido seguidas de forma generalizada (Taracena, 1941, 141-2; Taracena, 1947, 27). Si bien se han levantado algunas voces críticas no se han realizado excavaciones que las modifiquen o corroboren, y los materiales hallados por Schulten, que apenas jugaron algún papel en su intepretación, permanecen en su mayor parte inéditos.

En la actualidad la Gran Atalaya de Renieblas ha sufrido una repoblación espontánea de encinas, lo que hace bastante irreconocible el lugar. No se puede seguir el trazado de las murallas, y lo único visible son los restos de la casamatas del campamento III. El campamento $\mathrm{V}$ está en la falda de la colina, bajo tierras de labor. No se ha realizado ningún trabajo desde la excavación de Schulten.

\section{- Almazán (Soria)}

Ocupa una terraza colgada en el borde meridional del valle del Duero, sobre un antiguo meandro del río, que ahora corre a 350 metros, y tres kilómetros río arriba de la localidad de Almazán. En la actualidad, una cantera de graba y una repoblación de pinos han hecho desaparecer todo resto, y resulta incluso difícil de identificar el lugar que ocupó en la topografía del terreno.

Schulten realizó una cata en 1911 y un año después daba cuenta de su existencia (Schulten, 1912, 96-9). En 1927 comprobó grandes destrucciones en el recinto (Schulten, 1927, 198- 
200), lo que menciona en obras posteriores (Schulten, 1928, 36; 1929, 187-190). Taracena lo recoge (Taracena, 1941, 34; Taracena, 1947, 18). En 1969 fue objeto de una excavación de urgencia para determinar su estado de conservación y determinar su cronología real (Gamer y Ortego, 1969).

Las excavaciones sucesivas han revelado una muralla de dos paramentos exteriores rellena con guijarros bastante grandes (Gamer, Ortego, 1970, 71). Se conserva hasta poca altura aunque en 1912, se elevaba casi $1 \mathrm{mtr}$. (Schulten, 1912, 97). Planta rectangular, de casi 38 has., aunque se han perdido los lados sur y este del perímetro. En el lado oeste se observan restos de un foso y una puerta. Son todavía visibles las trazas de otra en el lienzo norte. Ambas se hallan protegidas por tituli o muros avanzados (Taracena, 1941, 34; Gamer y Ortego, 1970, 68-9).

Schulten lo data en tiempos de la guerra numantina, y posiblemente en el 153. Sería un campamento temporal de Nobilior, que según sabemos por Apiano, 45, pasó por esta zona camino de Numancia (Schulten, 1914, 30; Schulten, 1929, 187-190). Al año siguiente las fuentes (Apiano, 48-49) sitúan un nuevo ejército romano al mando de Claudio Marcelo, acampado en las cercanías de Ocilis (Medinaceli). Las excavaciones de 1968 revelaron una fecha que bien podía corresponder a este momento (Gamer y Ortego, 1970, 74-5). Otros investigadores han seguido a través de las fuentes las campañas de Nobilior y encuentran justificado un campamento aquí, entre Ocilis y Numancia, en la vía que asciende desde el valle del Jalón hacia la Meseta Superior (Calama y Rosellon, 1972, 147-8).

\subsubsection{La guerra de Sertorio (83-72 a.C.)}

\section{- Castra Caecilia (Cáceres)}

La preocupación por identificar los campamentos fundados por los romanos durante el curso de las guerras sertorianas arranca del siglo pasado (Fernández Guerra, 1889, 141), impulsada sin duda por la presencia de nombres alusivos en las fuentes. De nuevo nos encontramos con la figura de Schulten, que recoge la existencia de un campamento en 1918 (Schulten, 1918, 76-105, y más tarde en Schulten, 1926, 92-98), y realiza con posterioridad varias campañas arqueológicas (Schulten 1928, 1930, 1931b y 1932). La metodología científica de este investigador ha experimentado un avance respecto a las excavaciones de Numancia: se considera por primera vez la importancia cronológica de los materiales, simbolizada en su publicación conjunta con los datos planimétricos y arquitectónicos (Paulsen, 1928, 1930, y 1932).

Después de más de cuarenta años de abandono, la investigación se ha reanudado gracias a Beltrán Lloris, que reestudia los materiales cerámicos y numismáticos (Beltrán Lloris, 19734 y Beltrán Lloris, 1976) y sobre todo Ulbert, que ha realizado una concienzuda reexcavación del campamento (Ulbert, 1984), hasta ahora el mejor estudio arqueológico sobre un recinto de este tipo en el panorama científico español. Recientemente otros investigadores vuelven a referirse a Cáceres el Viejo sin citar datos nuevos (Alonso Sánchez, 1985 y 1988).

Es un campamento rectangular, pero con esquinas en ángulo agudo, a diferencia de los imperiales. Su trazado interno es rigurosamente polibiano para Schulten (Schulten, 1932, 335). 


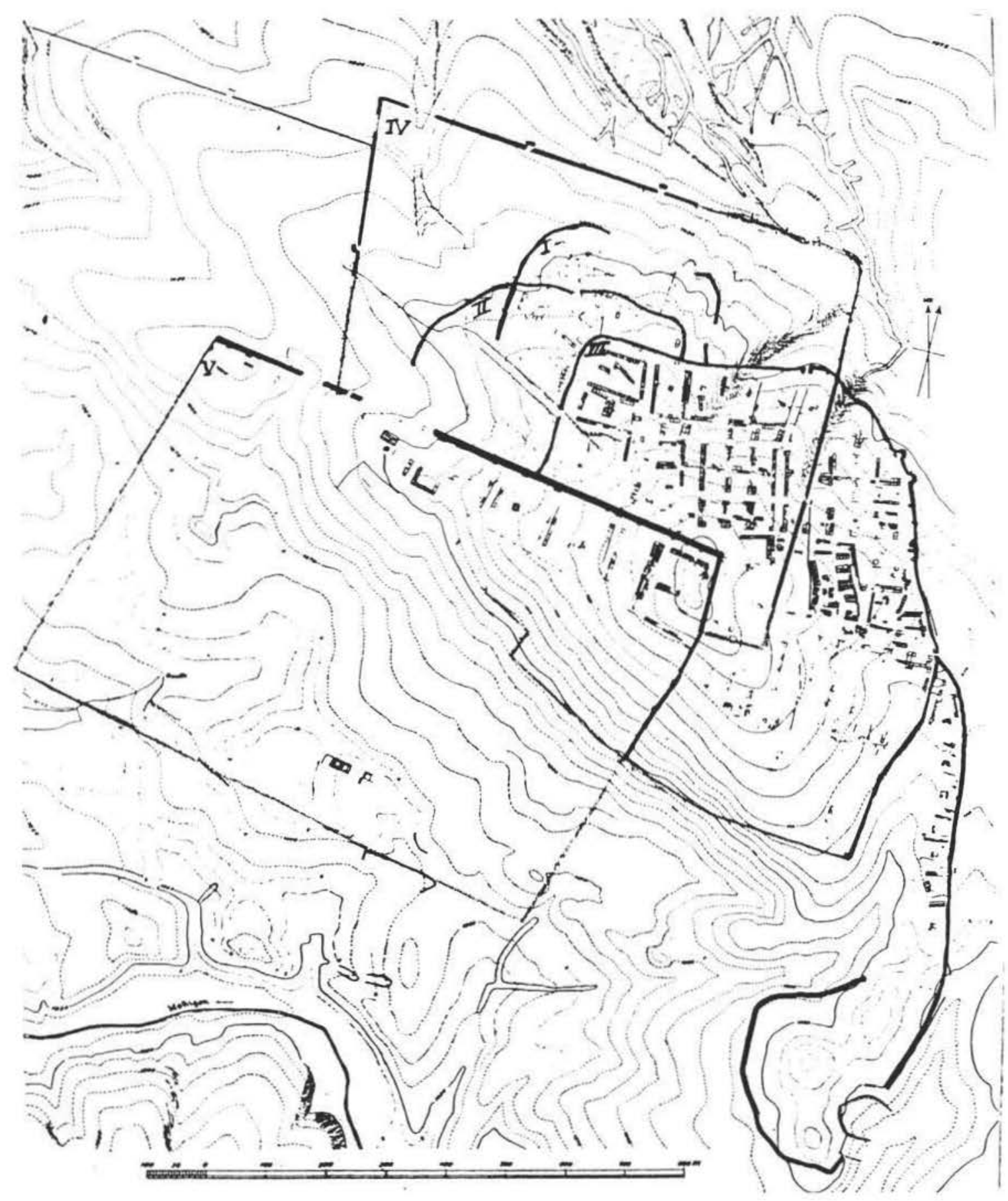

MaBstab: i : to000

Figura 5.-Planta de los campamentos de Renieblas, Soria (Schulten, 1945). 
La muralla mide aproximadamente 4 metros de anchura y está construída mediante dos muros paralelos con un relleno intermedio de tierra y piedras. Foso doble, el más exterior de 2 metros y el interno de 3 a 4 mtrs. de ancho, con un intervalo entre ambos de $2 \mathrm{mtrs}$. El foso se documenta muy bien en la esquina sudeste (Schulten, 1932, 335-7; Ulbert, 1984, 17-18). Ulbert ha creido reconocer un tituli o torre de protección (Ulbert, 1984, 17-18. Se conservan restos de cuatro puertas, praetoria, principalis dextra, principalis sinistra y quintana sinistra. No han aparecido restos de las otras dos que debieron existir. Tampoco hay testimonios de torres alrededor del perímetro o flanqueando las puertas.

Su cronología e identificación histórica ha levantado mucha polémica. Para Schulten este recinto sería construido por Q. Caecilio Metelo, gobernador de la Ulterior durante la sublevación de Sertorio. El año de fundación fue el 79 a.C., coincidiendo con la expedición de Metelo hacia el Norte, que debió seguir una ruta similar a la vía de la plata, testimoniada por fundaciones como Metellinum, luego colonia romana, y Vicus Caecilius, conocido por los Itinerarios posteriores. En las fuentes figura también un asentamiento denominado Castra Caecilia (Tolomeo, II, 5, 8; Plinio, IV, XXII, 117; Itinerario de Antonino, 434, 4), que parece corresponderse con este campamento. Las distancias señaladas en el Itinerario de Antonino coinciden con las medidas sobre el terreno. Cuando en el 77 Metelo, ante la inseguridad de sus posiciones, retira su ejército hacia el sur, es incendiado por las tropas sertorianas (Schulten, 1949, 92-98, ed. española de Schulten, 1926).

Las cuestiones que plantean mayores problemas son por un lado la fecha concreta de erección del campamento, y por otro, muy relacionado con el anterior, su identificación dentro de las diversas citas de textos clásicos. Las expediciones contra los Lusitanos llevadas a cabo en esta misma zona por Servilio Caepio en el 139 a.C., y por P. Licinio Craso entre el 96-94, han llevado a hablar de una Castra Servilia (citada en Apiano, 67-69) y una Castra Licinia, fundadas respectivamente por cada uno de ellos, y opciones alternativas para la identificación del campamento de cáceres el Viejo. Las fuentes (Tolomeo, II, 5, 8; Plinio, IV, XXII, 117) atestiguan la existencia en época imperial de dos vici con esos nombres, de los que podemos deducir un origen militar.

Schulten consideraba que Castra Servilia existió cerca de aquí, pero que no se uede considerar que sea este campamento (Schulten, 1932, 346). El estudio de los materiales llevado a cabo recientemente por Beltrán Lloris le lleva a conclusiones completamente distintas. Los hallazgos numismáticos se datan a finales del siglo II a.C., y la última pieza es del 93 a.C. (Beltrán Lloris, 1973-4, 271). Una opinión parecida le merecen las piezas cerámicas (Beltrán Lloris, 1986, 14-15). El autor concluye diciendo que: «el campamento tuvo que ser abandonado poco después de los años 96-95 a.C., y antes del 93 a.C.» (Beltrán, 1973-4, 295). Identifica Cáceres el Viejo con Castra Servilia o Castra Liciniana (Beltrán, 1973-4, 296-8; Beltrán, 1976, 16), pero no acepta que sea Castra Caecilia porque la datación de esta última es demasiado tardía.

La reinterpretación de los materiales llevada a cabo por Ulbert en 1.984 nos ofrece una cronología más reciente. Las monedas, las fíbulas, la vajilla de bronce y las lucernas avalan una fecha dentro de la primera mitad del I a.C., hecho confirmado por la calidad, la solidez y el lujo de las construcciónes (Ulbert, 1984, 203). El horizonte de incendio y la aparición de elementos importantes como los timateria del templo indican que el campamento fue incendiado por sorpresa, no al abandonarlo sus ocupantes (Ulbert, 1984, 204). En conclusión, sería un 
campamento de invierno, la Castra Caecilia de las fuentes, fundada por Caecilio Metelo, y destruída entre el 80 y el 72 a.C. No tuvo que desaparecer necesariamente tan pronto como propone Schulten (en el 78), y pudo resistir algunos años a pesar del repliegue del gobiernador bético hacia el sur (Ulbert, 1984, 207-8). El autor se pregunta por la causa de la inexistencia de restos de cannahae y por el emplazamiento que ocuparon Casta Servilia y de Castra Liciniana, cuya fundación en esta misma región y en una época anterior entra dentro de lo posible (Ulbert, 1984, 208-9).

\section{- Pompaelo (Navarra)}

Muy poco podemos decir del presunto origen castrense del núcleo urbano de Pompaelo. El nombre y la tradición han llevado a atribuir a Pompeyo la fundación de la ciudad en el 75-74 a.C., como campamento de invierno para sus tropas (Mezquiriz, 1978, 9), basándose en una cita de Salustio (II, 93). La arqueología no ha revelado restos constructivos en el solar de la actual Pamplona que puedan confirmar este origen. La presencia de cerámica campaniense fechable entre el 150 y el 50 no resulta argumento suficiente (Mezquiriz, 1976, 191). Sin embargo, esta investigadora cree reconocer el presidio en el núcleo antiguo de la Navarrería (Mezquiriz, 1976, 191).

\subsubsection{Otros campamentos republicanos}

- Alpanseque (Soria)

Situado en el límite entre las provincias de Soria y Guadalajara. Fue descubierto en 1916 por el Marqués de Cerralbo (Aguilera y Gamboa, 1916, 86-7), y más tarde recogido en las publicaciones de Schulten (Schulten, 1927, 199-200; Schulten, 1928, 36; Schulten, 1929, 1969) y Taracena (Taracena, 1941, 36; Taracena, 1947, 28), pero nunca ha sido excavado.

Se localiza en el paraje conocido como «Dehesa de los Santos», entre las localidades de Barahona y Alpanseque. Parece ser poligonal y de unas 4,7 has. Schulten lo considera un campamento de verano y lo atribuye a la campaña de Caton del 195 (Schulten, 1928, 36). En el momento actual no se reconoce su perímetro.

\section{- Navalcaballo (Soria)}

Taracena da la noticia de la existencia de un campamento en 1939 (Taracena, 1939), y en otras publicaciones posteriores (Taracena, 1941, 120; Taracena, 1947, 28). Este arqueólogo observa restos de un recinto rectangular de 705 x 440 mtrs. en la llanura junto al río Mazos, y cerca de la vía que unía el Jalón con la calzada Asturica-Caesaraugusta. Cree reconocer un agger con terraplén, foso y empalizada, en dos largos surcos paralelos respaldados en su interior por una loma ancha y aplastada. La diferencia entre el fondo del surco y la zona más 
alta de la loma es de sólo 60-80 cms. (Taracena, 1939 1-2). Taracena lo clasifica como un campamento de verano de madera, que fecha ex silentio en época de Sertorio. Plantea la posibilidad de que pertenezca a las tropas pompeyanas, que contaban con la fidelidad de la zona, pero por la cerámica del entorno y por su planta rectangular habría que considerarlo imperial (Taracena, 1939, 5).

Desconocemos la situación actual de este supuesto campamento, que nunca ha sido excavado y, por lo tanto, si tal atribución responde a la realidad.

\subsection{CAMPAMENTOS ROMANOS DE ÉPOCA ALTOIMPERIAL}

Al igual que los campamentos republicanos los hemos dividido para su estudio en varios períodos cronológicos, correspondientes a fases de intensa actividad constructiva desde el punto de vista militar. Algunos de ellos los estudiaremos en distintos momentos, siguiendo sus transformaciones sucesivas.

Los recintos militares de época imperial presentan diferencias notables respecto a los anteriores. En nuestro país su estudio comienza mucho más tarde que el de los republicanos, hecho debido más a una simple casualidad que a una voluntad específica en este sentido. Además, su morfología y aparejo constructivo varían considerablemente respecto al período republicano.

Pero el hecho más significativo es su distribución geográfica. Se concentran en el cuadrante noroccidental de la Península Ibérica, generalmente al píe de la Cordillera Cantábrica y los Montes de León. Tal emplazamiento responde a una concepción estratégica de larga duración, puesta en práctica por Augusto y sus sucesores. La conquista del Norte de la Península, y su consolidación posterior, que coincide con el establecimiento de la política de limes en las fronteras del Imperio, determinan la creación de establecimientos militares fijos. Para Roldán, en la mente de Augusto esta concentración militar tuvo una finalidad de glacis protector de la zona romanizada, a la vez que un instrumento de explotación económica (Roldán, 1976, 140). Pero este papel vigilante que tuvieron las fuerzas militares en un primer momento dió paso a otra función mucho más importante por sus consecuencias ulteriores, plasmada en las formas territoriales de implantación militar, muy bien estudiada por Le Roux (Le Roux, 1982, 9 y ss.), y con conocidos paralelos en otras regiones marginales del Imperio (Forni, 1970, 211-2 y 215). El control de las explotaciones mineras y la conservación de las comunicaciones expeditas sería su misión principal. Pero, como apunta Roldán, la conquista introduce un numeroso contingente humano foráneo que se superpone al local, y que trae como consecuencia la transformación de las estructuras preexistentes (Roldán, 1984, 71). Tales procesos se verifican en los primeros núcleos semiurbanos, que tienen un indiscutido carácter militar. El papel desempeñado en la reordenación del territoiro y la creación de nuevas estructuras sociales, que caracteriza a los recintos castrenses de época imperial, los distingue radicalmente de los republicanos.

En época de Tiberio parece tener lugar una redistribución de las fuerzas militares dentro de la Península, según se desprende de los capítulos 3, 8 y 4, 20 del libro III de la Iberia de Estrabón. Este autor señala que Tiberio estableció entre los Cántabros y Astures tres legiones, dos al mando de una legado en la región al Norte del Duero, y la restante al mando de otro le- 
gado en la región que se extiende entre el límite de los cántabros y astures hasta los Pirineos. No menciona el nombre de las legiones ni su emplazamiento concreto.

La mayor parte de los esfuerzos han ido encaminados a identificar su lugar de asentamiento. más que a su estudio y excavación.

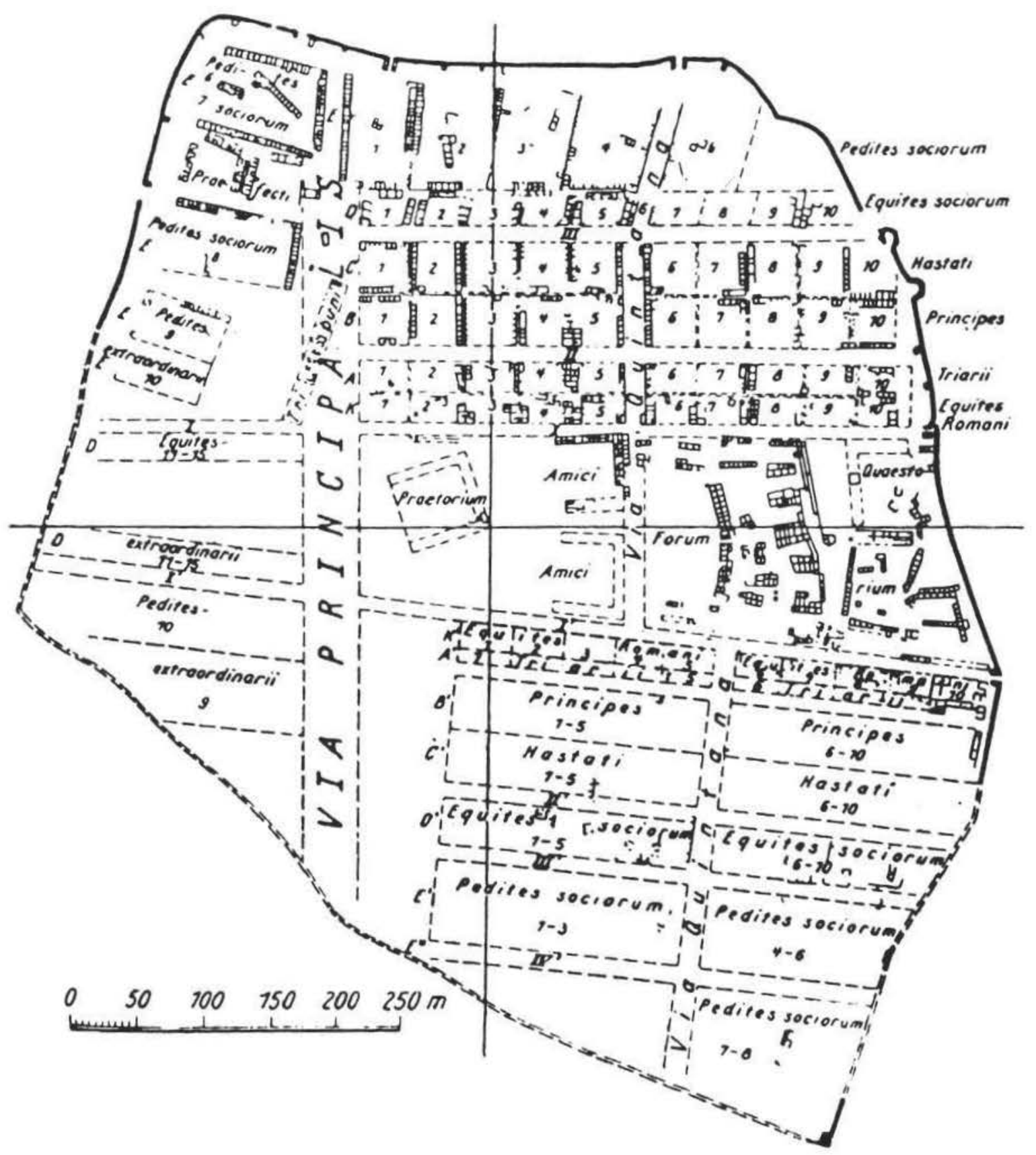

Figura 6.-Planta del campamento n." III de Renieblas, Soria atribuido al procónsul Nobilior (Schulten. 1945). 


\subsubsection{Los campamentos augusteos y tiberianos}

No vamos a entrar aquí en el análisis de los cuerpos militares que participaron en las campañas augusteas desarrolladas en el Norte de la Península. Se documentan contados datos proporcionados por las fuentes escritas y los restos arqueológicos, epigráficos y numismáticos. Varios autores se han ocupado suficientemente del tema (García y Bellido, 1961, 115-149; Roldán Hervas, 1974, 181; González Echegaray y Solana Sainz, 1975; García y Bellido, 1976, 62; Le Roux, 1982, 61-65, entre otros). Lo mismo podemos decir acerca del desarrollo de las operaciones durante las guerras del 26-19 a.C., y las múltiples discusiones al respecto. Todos estos trabajos de análisis de fuentes tienen una utilidad relativa para nosotros, ya que sólo proporcionan hipótesis no comprobadas sobre localización camapmental. Las publicaciones arqueológicas son, por el contrario, muy escasas, pero a ellas debo ceñir nuestro estudio.

\section{- Sasamón (Burgos)}

Constituye según todos los autores el asiento del principal campamento augusteo durante las operaciones contra los pueblos de la Cornisa Cantábrica. Las fuentes señalan que Augusto asentó su campamento apud Segisama (Floro II, 33, 48 y Orosio VI, 21, 3), lo que ha llevado a los investigadores a buscarlo en este núcleo indígena (Magie, 1920; Syme, 1934, 193-4; Schulten, 1943, 129 y 175-6; Schmittener, 1962; González Echegaray, 1966, 145; Syme, 1970, 89; Roldán Hervas, 1974, 181; Rodríguez Colmenero, 1979, 77-81 entre otros). La discusión se centra en el hecho de que existen dos asentamientos con nombre parecido, Segisama Iulia y Segisamo, y no está muy claro a cual de los dos se refiere la cita recogida por Floro y Orosio. Schulten decía que el ejército se emplazó junto a Segisamo, que estaría a orillas del río Brulles, núcleo que tras la marcha del ejército recibe el nombre de Segisama lulia. Segisamo y Segisama estaban en diferentes lugares (Shculten, 1943, 175-7); Rodríguez Colmenero asegura que la población actual fue el asiento del campamento, dándole el nombre de Segisama, distinta a Segisama Iulia (Rodríguez Colmenero, 1979, 77-81): Roldán se inclina por un recinto militar situado al norte del pueblo actual, donde aparecen numerosos restos (Roldán, 1974, 181).

En 1975 Abasolo da cuenta en una publicación de lo que considera que es el trazado del antiguo campamento bajo el pueblo actual. Realiza la identificación mediante la fotografía aérea y su principal argumento es la existencia de una vía romana prolongado lo que sería el cardo (Abasolo, 1975, 129-30). El recinto mediría 250 × 140 de lado, y abarcaría sólo 3,5 has., que el autor reconoce que es mucho menos que otros campamentos conocidos (Abasolo, 1975, 130). El campamento se situó en la misma colina que el poblado turmodigo, y junto a él. Con la marcha de la legión surge el asentamiento civil de Segisama Iulia, que se extiende también por el núcleo indígena (Abasolo, 1975, 131-2).

El campamento no se ha constatado arqueológicamente y su existencia sigue siendo cuestionable, a pesar de los datos de las fuentes y los estudios planimétricos. Por otro lado, no existe ningún material publicado que nos permita llevar la cronología hasta el 26 a.C. La localización dada por las fuentes de un campamento «junto a Sasamón» tampoco es muy exacta, y podría referirse a algún núcleo cercano, quiza Herrera de Pisuerga. 


\section{- Herrera de Pisuerga (Palencia)}

La situación es este núcleo urbano, antigua Pisoraca de las fuentes, es totalmente diferente a la de Sasamón. Los textos carecen de noticias que permitan localizar un asentamiento militar en Herrera. Sin embargo, los materiales proporcionados hasta ahora por las excavaciones arqueológicas que vienen llevándose a cabo desde hace varios años, revelan unas cronologías perfectamente asignables a las primeras campañas de las Guerras Cántabras (Pérez González, 1989). Se considera asiento de la Legio IV Macedonica.

La presencia en España de dicha legión resulta suficientemente atestiguada a través de los restos arqueológicos y epigráficos (González Echegaray y Solana Sainz, 1975). Los más importantes de estos son los llamados hitos augustales, mojones de delimitación de los campos de la legión (Fita, 1891, 457 y ss; Huidrobo, 1929, 492 y ss; García Díaz, 1945, 82-86), las estampillas del alfarero L. Terentius, figlinarius de la Legio IIII, aparecidas en gran cantidad en Herrera de Pisuerga (García y Bellido et alii, 1962, 29-37; Balil, 1984, 171-173), además del problemático y seguramente erróneo ladrillo de Campo Valdés (Fita, 1905, 80-1).

Las llamadas Tablas de barro de Astorga, o Itinerario del Barro constituyen un testimonio muy discutido de la presencia de la legión. La Tabla I recoge una vía que se dirige desde Legio VII hasta Portus Blendium (Suances, Santander), pasando por varias mansiones intermedias una de las cuales es llamada Legio IV. El documento ha sido estudiado por varios autores (el tratamiento más detallado del tema se encuentra sin duda en García y Bellido, 1975), pero recientemente Roldán ha cuestionado su autenticidad (Roldán, 1972-3, 228-9). Aparte de consideraciones generales sobre el tipo de letra, el autor considera inviable la existencia y mención simultánea de la Legio IV y la Legio VII. La primera aparece documentada en el año 45 d.C., en Germania y debió partir de la Península en época de Claudio (Roldán, 1974, 183), mientras la segunda no pudo obviamente establecerse en una época anterior a su fundación por Galba. para Roldán: «Sería absurdo concebir que las hipotéticas cannabae formadas a su vera (de la Legio IV) en tan corto período de tiempo hubieran desarrollado un núcleo urbano que continuase existiendo tras su desaparición con el mismo nombre» (Roldán, 1972-3, 229). No vemos tan lógico el razonamiento de Roldán, ya que en un período de cuarenta años pudieron formarse perfectamente cannabae, y respecto a la pervivencia del nombre, si bien no es corriente, tampoco es imposible. Una opinión similar expresa Le Roux (Le Roux, 1982, 106-7), apuntando que el origen de la vía en León puede hacer referencia a una vía augustea que salía del mismo punto, siempre que se acepte que esta ciudad era el asentamiento de la Legio VI tras las Guerras Cántabras. No está muy claro el valor real que hemos de conceder a este documento epigráfico.

García y Bellido situó el emplazamiento de la legión en Aguilar de Campoó, con argumentos simplemente geográficos basados en la distribución de hitos augustales (García y Belido, 1961, 119 entre otros); Shculten (1943, 178-80) y González Echegaray-Solana (1975, 181-2) comparten la opinión de García y Bellido. Roldán en 1972-3 la sitúa en Castrillo del Haya, no lejos de Aguilar (Roldán, 1972-3, 228-9), aunque algunos años más tarde ya acepta su permanencia en Herrera (Roldán, 1984, 71). Pérez González es el primero que asegura tajantemente que Herrera de Pisuerga fue el asiento de la Legio IV o de parte de ella (Pérez González, 1981, 146-160), hecho que han confirmado sus escavaciones posteriores, al menos desde el punto de vista material (Pérez González, 1989; Fernández Ibañez y Pérez González, 1990; Morillo Cerdán y Peréz González, 1989, entre otros). 
Pérez González cree reconocer huellas de un trazado campamental en el actual núcleo de Herrera (Pérez González, 1981, 147), pero aún no se ha encontrado resto alguno que pueda ser atribuido con seguridad al recinto fortificado. La distribución de los hitos augustales y el hecho de que Pisoraca fuera el punto de partida de dos antiguas vías que llevaban respectivamente a Suances y Castro Urdiales son también datos a tener en cuenta para este autor.

Las últimas campañas arqueológicas han puesto de manifiesto la existencia de estructuras de habitación bien fechadas en una fase augustea muy temprana, asimilables a viviendas militares, pero aún pendientes de interpretación.

El campamento sería abandonado hacia el 39-40 d.C., desarrollándose un núcleo urbano sobre sus cannabae.

\section{- Asturica Augusta (León)}

La mayoría de los investigadores sobre las Guerras Cántabras considera Astorga como uno de los campamentos augusteos (Schulten, 1943, 129; Schmittenner, 1962, entre otros). Luengo y Mañanes, los autores que han dedicado su atención a este asentamiento mantienen esta opinión sin discusiones, a pesar de que no hay resto alguno que la avale. Luengo, en distintas publicaciones recoge el origen campamental de la ciudad (Luengo, 1961, 152), que el atribuye a la Legio X Gemina a partir de los epígrafes embutidos en la muralla bajorromana (C.I.L. II, 2631). Mañanes cree observar huellas de una típica estructura campamental, rectangular, con

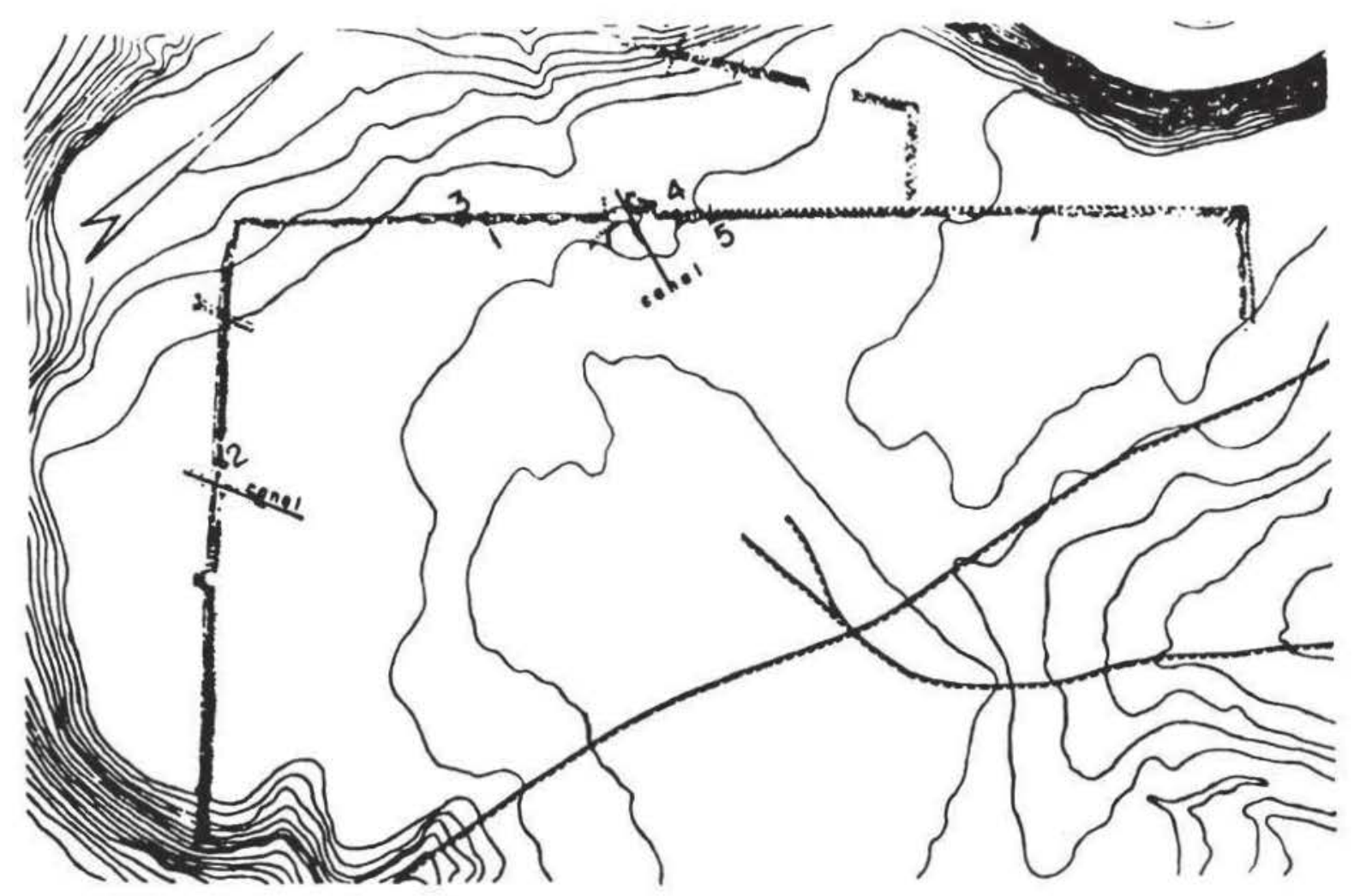

Figura 7.-Planta del campamento de Almazán, Soria (Gamer y Ortego, 1969). 
calles en retícula (Mañanes, 1976, 77; Mañanes, 1983, 13; Mañanes, 1984, 216). No se muestra muy seguro de la presencia de la susodicha legión, debido a los hallazgos de Rosinos de Vidriales (Mañanes, 1983, 13), y reconoce que no está comprobado.

La discusión entre estos autores se centra no tanto en el carácter militar primitivo de la población, que consideran asegurado, sino en el año de establecimiento del mismo y la preexistencia de un núlceo indígena. Para Mañanes tiene lugar una fundación militar ex-novo el año 25 a.C. (Mañanes, 1976, 77-78), seguida de una ocupación civil del campamento (Mañanes, 1983b, 146). Luengo se inclina por un asentamiento prerromano (Luengo, 1961, 153). Pastor Muñóz, que trata sobre el problema en el «Symposium de Ciudades Augusteas», sigue a Luengo en el origen prerromano y presenta el paso de campamento a ciudad en el año 19 o entre el 15-13 a.C., fecha de la supuesta segunda venida de Augusto a la Península (Pastor Muñóz, 1976, 72-3).

En la actualidad lo único que parece aclarado es que no existe un núcleo indígena sobre el lugar donde más tarde se erige la ciudad romana. No hay datos concluyentes sobre la presencia del campamento, y tampoco sabemos con certeza la fecha de establecimiento de éste (si alguna vez existió). Sobre su tranformación en ciudad, que la investigación ha leído de forma generalizada en el pasaje de Floro II, 33, 54, donde habla de la bajada al llano de los indígenas, obligados por Augusto a habitar su propio campamento, persisten numerosas incógnitas.

Respecto a la existencia de un recinto murado bajoimperial, no tenemos ninguna prueba de que se levantara encima de otro recinto más antiguo, y menos aún podemos saber si éste pertenecería a la ciudad o al campamento.

Recientemente V. García Marcos ha continuado las excavaciones arqueológicas en esta ciudad leonesa (García Marcos y Vidal Encinas, 1990).

\section{- Rosinos de Vidriales (Zamora)}

Schulten en 1927 y Gómez Moreno en el mismo año dan cuenta de la existencia de este campamento (Schulten, 1927, 202-3; Gómez Moreno, 1927, 47-51). García y Bellido lo recoge (García y Bellido, 1961, 136-7). Ha sido excavado parcialmente por Martín Valls y Delibes de Castro (Mar'tin Valls y Delibes de Castro, 1975). Estos autores han publicado algunos hallazgos aislados (Martín Valls y Delibes de Castro, 1973, 408-9; 1968, 337-339; 1980, 120 $122 ; 1981,117-180 ; 1982,54-62 ; 1990,155-164)$, al igual que Gamer (Gamer, 1975, 277-8) y Balil (Balil, 1986, 243-245). Recientemente se ha reanudado su excavación.

En realidad son dos campamentos, incluído uno dentro del otro. El más grande apenas resulta visible si no es mediante fotografía aérea, sus dimensiones son 12, 59 has. La aparición de sillares en el curso de las labores agrícolas permite suponer que tuvo una muralla de piedra (Martín Valls y Delibes de Castro, 1975, 6). Este ha permanecido oculto hasta los trabajos de excavación realizados en la década pasada. El más pequeño coincide con el anterior en sus lados Noreste y Sureste. Al igual que aquel es rectangular con ángulos redondeados, ejes de 244 x 193 mtrs., y una extensión de 4,70 has. Presenta un muro de hormigón revestido con sillares, que se conservan sobre todo en la cara externa de los lados Sureste y Suroeste, gracias a la erosión de un arroyo cercano. Puede seguirse perfectamente en todo su perímetro a excepción 


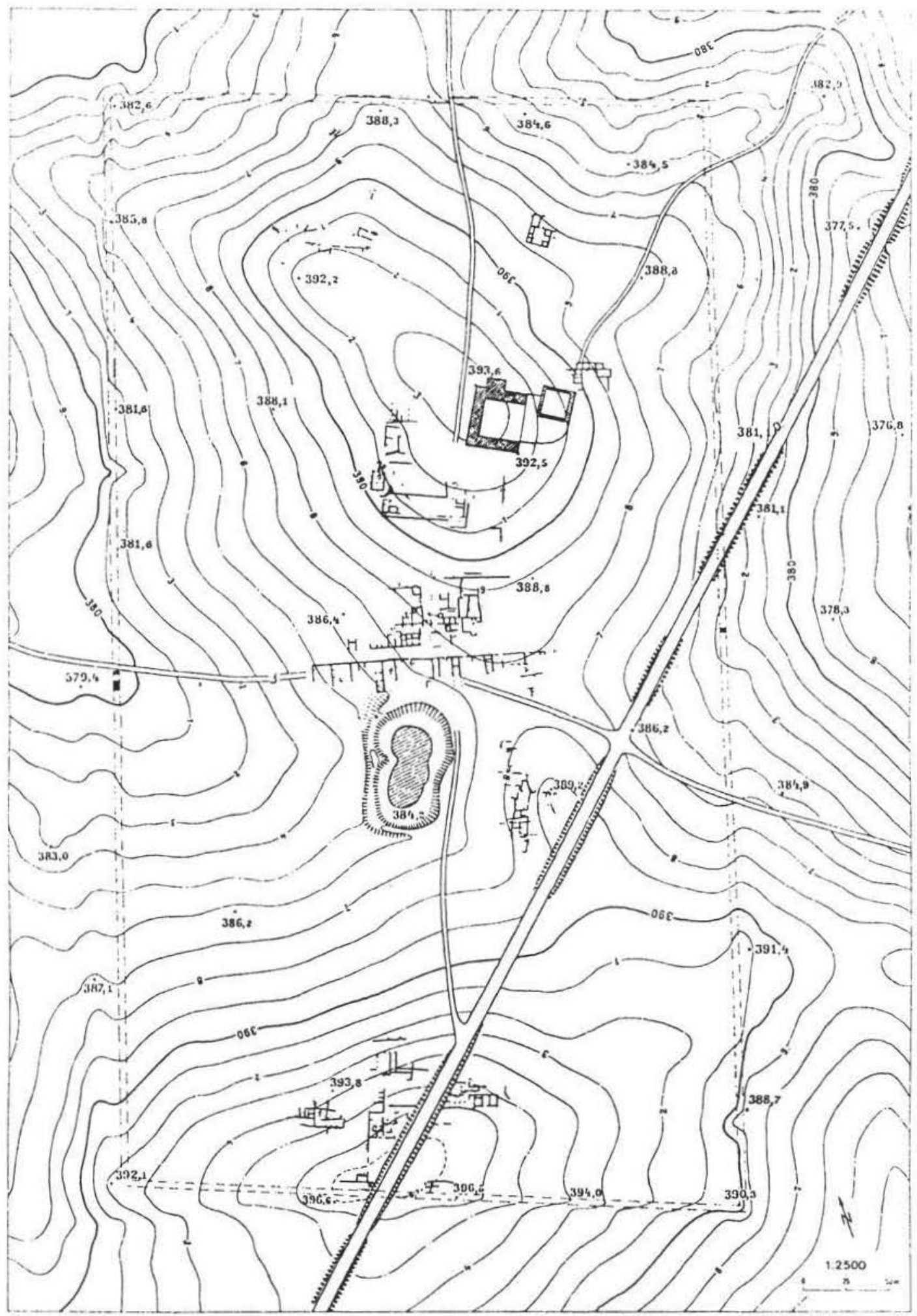

Figura 8.-Planta del campamento de Cáceres el Viejo, Cáceres (Ulbert, 1984). 
de un tramo muy pequeño en la cara oeste. La altura de los lienzos conservados varía entre 1 y 3 metros. Una carretera actual lo corta de forma paralela a sus lados menores, utilizando quizás las antiguas entradas (Martín Valls y Delibes de Castro, 1975, 3-4). Este fue el campamento dibujado y descrito por Schulten.

La existencia en un mismo lugar de dos campamentos ha dado lugar a numerosas confusiones en cuanto a su edificación. El menor se ha atribuido a distintas unidades: Schulten a la Cohors IV Gallorum (Schulten, 1927, 203); Gómez Moreno a la Legio X Gemina (Gómez Moreno, 1927, 47-8); Vigil al Ala II Flavia Civium Romanorum (Vigil, 1961, 110). La presencia de esta última unidad está testimoniada por la epigrafía (García y Belido, 1961, 136; García y Bellido, 1966, 28-30; Vigil, 1961, 104-5. Pero también han aparecido en las cercanías varias lápidas funerarias pertenecientes a soldados de la Legio X, así como una tégula con marca de la misma legión (García y Bellido, 1961, 127; Martín Valls... 1975, 5).

La solución parece estar en la existencia de dos ocupaciones sucesivas. La legio X ocuppo el campamento grande en la época de las Guerras Cántabras, ya que el pequeño no es lo bastante grande para acoger a una legión. La presencia de sigillata aretina avala esta datación (Balil, 1986, 243-5). En el 62 abandona la Península, y regresa temporalmente entre el 68-70, aunque no sabemos si volvió a este lugar (García y Bellido, 1961, 128). En un momento aún indeterminado se construye sobre el anterior un campamento para una unidad más reducia, el Ala II Flavia Civium Romanorum. Los excavadores proponen finales del siglo I o principios del II, ya que por la epigrafía sabemos con seguridad que está aquí asentada a mediados de ese mismo siglo (Martín Valls y Delibes de Castro, 1975, 6). La Notitia Dignitatum sitúa en Paetaonio (corrupción de Petavonium, mansión cercana a Vidriales) a los Cohors II Flavia Pacatiana, pero carecemos de testimonios de ningún tipo sobre su presencia (Martín Valls y Delibes..., 1975, 7), aunque Barbero y Vigil la consideran la misma unidad que el Ala II Flavia (Barbero y Vigil, 1965, 276). Apenas hay restos de los siglos III y IV, pero no podemos precisar el momento en el que tuvo lugar su abandono. Se conserva una lápida de mediados del siglo III que puede ser atribuida al Ala II Flavia, lo que confirmaría su presencia hasta esta fecha (Martín Valls y Belibes, 1975, 10).

\section{- Otros recintos campamentales: Valdemeda, Lugo, Iuliobriga y Castrencias}

La arqueología o las fuentes nos hablan de la existencia de otros recintos posiblemente militares datados a finales del siglo I a.C., y primeras décadas del siguiente. Si exceptuamos el de Valdemeda, no están lo suficientemente testimoniados como para aceptar su carácter castrense.

El campamento de Valdemeda, en Manzaneda (León) fue descubierto por Sánchez-Palencia a través de la fotografía aérea y publicado poco después (Sánchez-Palencia, 1986; Fernández-Posse y Sánchez-Palencia, 1988, 149-50), pero aún no ha sido excavado. Está situado sobre un pequeño llano a 500 metros del río Eria, y rodeado por dos arroyos al este y al oeste. Se trata de un recinto "casi perfectamente rectangular», con ángulos redondeados y orientado hacia el Norte. Sus ejes varían entre 260-5 x 165-170 metros, ocupando una superficie de 4,2 a 4,5 has. Consta de un terraplén a lo largo de todo el perímetro y foso en alguno de sus lados (NW, SW y S). En el centro del lado sur del recinto parece existir una puerta protegida con 
dos recodos, externo e interno, y hay restos de otra entrada por el oeste. Por el centro de los lados norte y este atraviesan el campamento sendos caminos, lo que permite suponer el aprovechamiento de otras entradas. En la parte interna de la esquina noroccidental se conserva un amontonamiento de piedras, que quizá corresponde a una torre defensiva. Se observan acumulaciones de piedras siguiendo la alineación del terraplén, probablemente el relleno interno del muro.

Respecto a la cronología el único dato cierto es que estaba fuera de uso cuando le alcanzan las obras de una explotación aurífera cercana, esto es, hacia el 15-20 d.C. (Sánchez-Palencia, 1986, 229). Este autor le señala un momento de ocupación en la época de las Guerras Cántabras o inmediatamente posterior.

La función de este asentamiento militar parece relacionada de algún modo con la explotación minera. Ocupa una posición estratégica junto a importantes yacimientos auríferos, y en el punto intermedio entre las Cuencas del Duero y el Sil. Su presencia también puede estar ligada a la destrucción de asentamientos castreños cercanos como la Corona de Corporales (Sánchez-Palencia, 1986, 229). Este posible papel de vigilancia en la explotación aurífera supondría una novedad respecto a lo que conocemos hasta ahora de la función de los campamentos romanos en España, si bien algunos autores ya lo habían supuesto anteriormente.

La hipótesis de la existencia de un campamento en Lugo perteneciente a la época de las Guerras Cántabras fue formulada por Schulten en 1943. Este autor creyó reconocer un rectángulo intramuros del recinto amurallado, y formuló la propuesta de que fuese un campamento (Schulten, 1943, 177). Su interpretación ha sido aceptada por la investigación posterior. Arias Vilas mantiene en un primer momento la fundación castrense atribuyéndola a algún lugarteniente de Augusto, aunque reconoce que el trazado propuesto por Schulten plantea algunos problemas (Arias Vilas, 1976, 63-67), como es el hecho de que el recinto se amplie en el Bajo Imperio, a diferencia de lo que ocurre en todos los núcleos urbanos (Arias Vilas, 1972, 14-5; Arias Vilas, 1976, 63-67; Arias Vilas, 1976 b, 57). No conocemos resto alguno de fortificación castrense en Lugo, y su existencia no pasa de ser una hipótesis de trabajo. La Notitia Dignitatum vuelve a citarla como asiento de una unidad militar en época tardorromana. Recientemente este mismo autor descarta totalmente la posibilidad de un origen campamental, ante la carencia de testimonios arqueológicos (Arias Vilas, 1984, 211).

En 1889 De Los Ríos sitúa en Castrillo del Haya, junto a Iuliobriga, dos campamentos de la época de las Guerras Cántabras, uno de invierno y otro de verano (De Los Ríos y Ríos, $1889,511)$. La idea es retomada en 1981 por Solana, que asegura que la ciudad de luliobriga sería el núcleo originado por las cannabae legionarias (Solana, 1981, 151). Este autor no define dónde se situó el campamento, y utiliza argumentos logísticos, más que arqueológicos. En la actualidad no se conserva resto alguno de construcciones que pudieran ser interpretadas como tales, y resulta bastante difícil pensar en un establecimiento militar en una zona tan al interior de la Cordillera.

Este mismo autor sitúa en Castrecías, cerca de Aguilar de Campoó (Palencia), otro campamento de la campaña del 26 a.C., junto con los de Herrera de Pisuerga y Iuliobriga. Lo atribuye a la Legio IX Hispana (Solana, 1981, 87). Pérez González también menciona esta posibilidad (Pérez González, 1984, 28). No hay ninguna prueba concluyente.

Frecuentemente se ha vinculado el asentamiento de Bracara Augusta (Braga), al Norte de Portugal, con los campamentos augusteos. Esta cuestión sigue siendo problemática y perma- 
nece al margen de nuestro ámbito de estudio (Rigaud De Sousa, 1973; Balil, 1976, entre otros).

\subsubsection{Campamentos de los siglos I-II d.C}

\section{- Castra Legionis VII Geminae}

Algunos investigadores consideran que en el emplazamiento de León existió un recinto campamental anterior al establecimiento de la Legio VII. García y Bellido en 1961 apunta la posibilidad de que la Legio VI Victrix se asentara en el solar de la actual ciudad de León (García y Bellido, 1961, 125), desde donde podía operar perfectamente contra los Astures sublevados el 55 d.C., como parecen indicar una lápida hallada en Rímini (C.I.L. XI, 395). Asimismo Alfoldy restituye a una lápida hallada en León la terminación «-trix», y la identifica como perteneciente a dicha legión (Alfoldy, 1969, 115). En 1968 García y Bellido constata la existencia de material tiberiano-claudio en la capital leonesa (García y Bellido, 1968, 31). Le Roux se inclina por esta posibilidada, que facilitaría el entendimiento de la Tabla I de Astorga, ya que haría referencia a una vía de tiempos de la conquista (Le Roux, 1982, 106-7). Jones apunta incluso que la existencia de un único legado para las legiones VI y X podría suponer un establecimiento conjunto en la región astorgana (Jones, 1976, 50-1). A pesar de estas opiniones y testimonios, que coincidirían bien con la posición estratégica de León, no hay restos constructivos visibles que avalen tal hipótesis.

Hasta el momento tenemos que considerar que la fundación de un recinto castrense en León tiene lugar hacia el 74, año de regreso de la legión VII a Hispania y de su instalación definitiva (García y Bellido, 1968 b. s/p). La elección del lugar tuvo en cuenta su cercanía a las explotaciones auríferas y a los pueblos norteños, así como la tupida red de comunicaciones de la zona, que permitía una perfecta operatividad.

A pesar de que las fuentes y los materiales arqueológicos no desestiman la existencia de un campamento en el último tercio del siglo I d.C., no hemos encontrado restos de las fortificaciones de las que sin duda debió de dotarse. Al igual que comentaba en el caso de Astorga no hay datos bajo el recinto murado bajoimperial para suponer una fase más antigua.

\section{- Castrocalbón (Zamora)}

Al estudiar en 1965 la fotografía aérea del trazado de la vía XVII del Itinerario de Antonino, Loewinsohn descubrió la existencia de dos recintos campamentales, a uno y otro lado de la calzada (Loewinsohn, 1965, 42-3). Han perdido prácticamente su forma, y sólo se conservan en pie algunos parapetos. Por los amontonamientos de piedra dispuestos a lo largo del antiguo perímetro se observa que la anchura del muro debía ser de aproximadamente 2 metros. Entre los dos campamentos se halla un túmulo circular de $30 \mathrm{mtrs}$. de radio, no muy alto, con la parte superior nivelada, que quizá corresponda a la plataforma de una torre de observación sobre postes de madera, similar a las del limes. Frente al campamento más pequeño hay restos de un tercero, cuya cara sur es aún visible. 
Su descubridor lo atribuye a la Cohors IV Gallorum, que García y Bellido ya había localizado en los alrededores tras la aparición del depósito de hitos augustales de Castrocalbón y Soto de la Vega (García y Bellido, 1961, 155-159). Jones, por el contrario, los considera unos campamentos de práctica o aprendizaje, donde se instruía a los soldados de la legio X, asentada en Rosinos de Vidriales, sobre las técnicas de castramentación (Jones, 1976, 59). La presencia de una torre de vigilancia constituye para Le Roux la evidencia del carácter temporal del campamento, establecido por razones desconocidas en un momento indeterminado, situado entre las campañas augusteas y el final del siglo I d.C. (Le Roux, 1982, 108).

Respecto a la cronología del recinto carecemos de información directa. Para García y Bellido la Cohors IV Gallorum salió de la Península hacia el 54 d.C., y por lo tanto el asentamiento debería ser anterior, pero no hay constatación arqueológica (García y Bellido, 1961, 155).

Desconozco la situación en que se halla este yacimiento en la actualidad.

\section{- A Cidadela (La Coruña)}

La existencia de un yacimiento romano es conocida desde antiguo en la localidad de A Cidadela, Sobrado dos Monxes (García Romero, 1909, 11-13). Del Castillo lo identifica como campamento romano (Del Castillo, 1931, 55), y realiza la primera excavación, de la que no se conserva más que un artículo publicado en «La Voz de Galicia» del 5 de Enero de 1935. También García y Bellido lo recoge (García y Bellido, 1969, 32-33). Es uno de los pocos recintos donde se han realizado excavaciones recientes con metodología científica, desgraciadamente incompletas (Caamaño Gesto, 1984).

Se sitúa en una meseta limitada al oeste y sureste por dos riachuelos. Caamaño descubre un recinto rectangular con esquinas redondeadas, orientado siguiendo un eje NW-SE, rodeado por un muro conocido como «a Cerca». El lado sur prácticamente ha desaparecido por causa de las labores agrícolas y la construcción de la iglesia. La muralla tiene aproximadamente 1 mtr. de grosor, con paramento de sillarejo. El ángulo Noreste está reforzado con sillares de granito. Se conservan restos de una torre a unos 25 metros de esta esquina hacia el sur, construída con sillares y adosada interiormente a la muralla. Los bloques de piedra de la muralla y la torre no se conservan porque fueron arrancados tras las excavaciones de 1934. Persisten huellas de un foso en el lienzo este. En el lado norte desapareció al construir un campo de fútbol, y el oeste fue utilizado para el paso de un camino. El foso de la cara sur fue utilizado para el paso de un camino. El foso de la cara sur ha desaparecido (Caamaño, 1984, 235-6).

Caamaño identificó dos montículos en la «Serra da Corda», 300 mtrs. al norte, como túmulos megalíticos reutilizados posiblemente como torres de vigilancia en época romana, como lo demuestran en su opinión diversos restos romanos. Soportarían torres de madera del mismo tipo que las del limes (Caamaño, 1984, 236).

La aparición de marcas de la Cohors I Celtiberorum sobre tégulas permite identificar la unidad ocupante del campamento. La Notitia Dignitatum (XLII, 30) señala el traslado de dicha cohorte desde Brigantium a Juliobriga, lo que confirma su presencia en la zona y proporciona una fecha «ante quem» a finales del III o principios del IV (Caamaño, 1984, 250-1). Desconocemos en que momento tuvo lugar el asentamiento. 
Su instalación aquí parece causada por intereses exclusivamente estratégicos, de control del paso desde la zona costera hacia el interior (Caamaño, 1984, 238).

\section{- Aquis Querquennis (Orense)}

Estudiado recientemente por Rodríguez Colmenero (Rodríguez Colmenero, 1977, 100-3; Rodríguez Colmenero, 1979, 183; Rodríguez Colmenero, 1983). Aquis Querquenis, mansión de la vía XVIII ha sido localizada por éste autor en «La Cidá» de Baños de Bande, que se encuentra anegada actualmente por el pantano de «As Conchas». Realizando excavaciones durante la época de estío, cuando bajan las aguas del pantano, encontró un amplio recinto rectangular, delimitado por un consistente muro con esquinas oblongas. La muralla presenta dos sectores superpuestos, los cimientos, de $1 \mathrm{mtr}$. de profundidad, trabajados de forma tosca, y el alzado propiamente dicho, que se conserva hasta una altura de $80 \mathrm{cms}$., con un aparejo de pequeños sillares cuadrados muy bien escuadrados. Relleno de capas de mampuestos irregulares asentados en arcilla. La anchura de la misma es variable, pero como mucho alcanza 4,30 mtrs. Se encontró un sillar semicircular que debía coronar la construcción, fuera contínua o almenada. Foso alrededor, con perfil en «U» $\mathrm{O}$ «V», de 4 mtrs. de anchura máxima y 3 de produndidad, y berma de $50 \mathrm{cms}$. (Rodríguez Colm, 1983, 249-253).

En la esquina del ángulo noroeste excavado se encontró la base de una torre que sobresalía del paramento exterior de la muralla más de $10 \mathrm{cms}$, y más de 30 en el interior. El acceso debía realizarse por una rampa interior. Rodríguez Colmenero considera que debieron existir torres en todas las esquinas, en los lados de las puertas y a lo largo del perímetro (Rodríguez Colmenero, 1983, 250-252), pero no excava en el lugar de las mismas. Intervallum intramuros de 4 mtrs. de anchura y restos de cubículos en el interior del recinto.

La cronología es imprecisa. Su excavador la considera posterior al año 50 d.C., basándose en los restos materiales. Además, la via Nova o XVIII del Itinerario de Antonino se terminó de construir el 79, y huelga decir que la presencia de un cuerpo del ejército requiere de forma imprescindible la existencia de buenas comunicaciones. (Rodríguez Colmenero, 1983, 254). Rodríguez Colmenero se inclina por la Cohors I Celtiberoru, porque se ajusta mejor al espacio que las unidades de Civium Romanorum (Rodríguez Colmenero, 1983, 256-8).

La identificación como recinto castrense y la cronología siguen planteando muchos interrogantes.

\subsection{CAMPAMENTOS Y FORTIFICACIONES URBANAS TARDORROMANAS}

La existencia de recintos militares fortificados en España durante el Bajo Imperio se apoya en dos argumentos principales: por un lado las noticias proporcionadas por las fuentes escritas, en concreto el pasaje XLII, 1, 25 de la Notitia Dignitatum; por otro la constatación de ciudades amuralladas durante los siglos III-IV. Sin embargo ninguna de ellas está exenta de problemas de la interpretación. La primera no ofrece garantias totales de autenticidad, y nombra emplazamientos totalmente desconocidos desde el punto de vista de la arqueología. Respecto a la segunda, no podemos considerar estríctamente como campamento ninguno de los recintos 
de este período, aunque resulte obvio su carácter militar, y como consecuencia desconocemos la diferencia entre fortificaciones de campamentos y de ciudades. La causa probablemente reside en que en este momento no hay entre éstas y aquellos una distinción tan estricta como en fases anteriores de la presencia romana. Le Roux lo define como una integración del elemento militar dentro de la vida ciudadana, que lleva a redefinir el espacio urbano (Le Roux, 1982, 392).

En lo que respecta a su disposición geográfica no se van a producir grandes transformaciones. El noroeste continúa siendo el área militar de interés prioritario, pero por motivos distintos de los que conocemos para el Alto Imperio. No parece existir una inquietud entre los pueblos del norte. las explotaciones mineras parecen en retroceso. La amenaza directa de una invasión durante el siglo III resulta también descartada. La causa de estas transformaciones parece residir en los cambios en la estrategia defensiva del Imperio romano, que se plasma en la división del ejército entre tropas fronterizas o limitanei y tropas de retaguardia o comitatenses, lo que supone una defensa en profundidad y una fortificación selectiva de ciudades y puntos concretos (Balil, 1956, 281-2; 1960, 182).

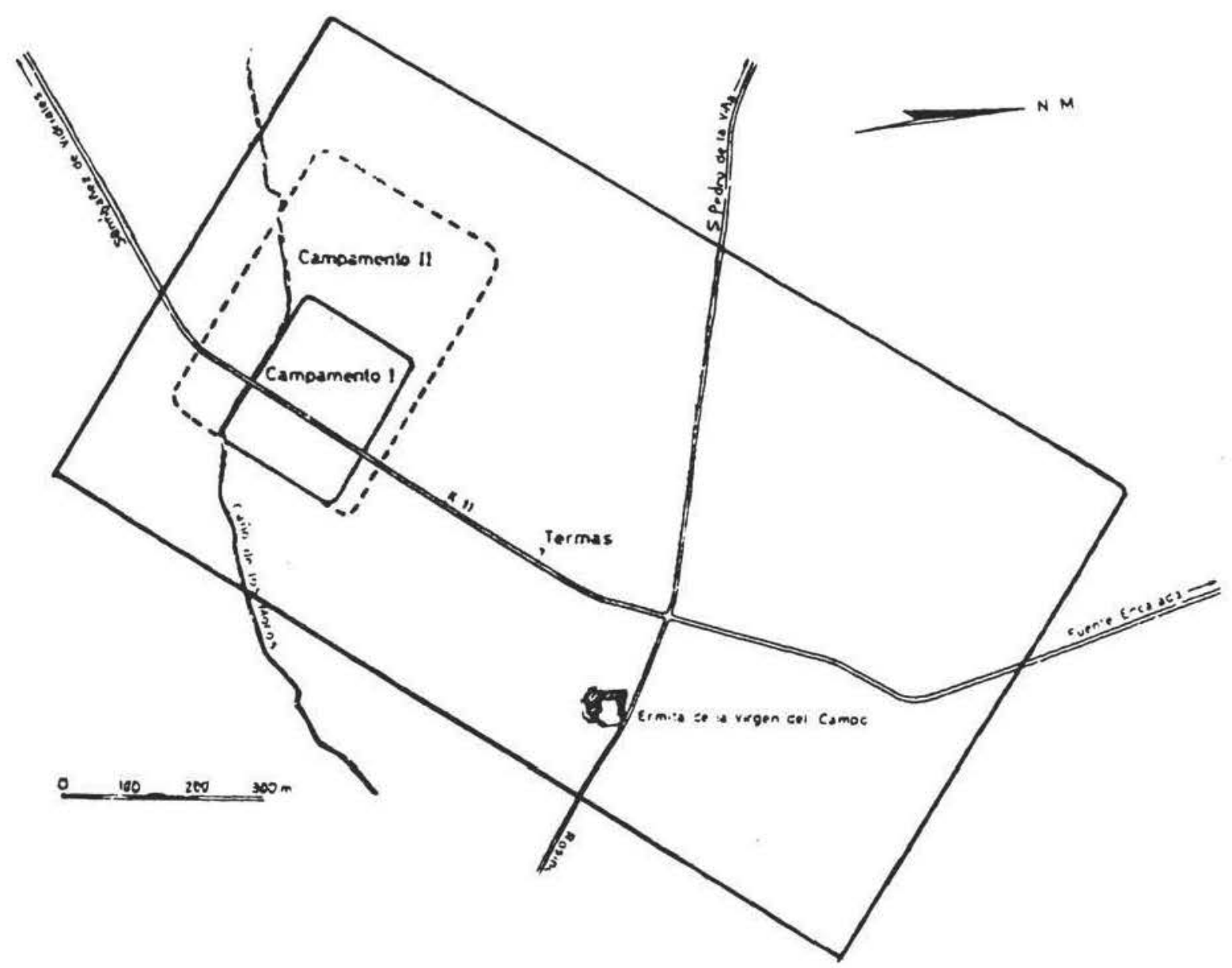

Figura 9.-Planta de los campamentos de Rosinos de Vidriales, Zamora (Martín Valls y Delibes de Castro, 1980). 
Tradicionalmente se han considerado las tropas mencionadas en la Notitia Dignitatum como limitanei. Arce rechaza esta atribución, y asegura que son un tipo específico de tropas, praepositurae a cargo de un magister militum (Arce, 1980, 598-90. El status de limitanei lo único que indica es que tienen establecimientos fijos, pero no son tropas de frontera. No se puede considerar que exista un limes en el Noroeste (Arce, 1982, 67-68; Fuentes Domínguez, 1989), tal como habían opinado algunos autores (Vigil y Barbero, 1956, 271-339 entre otros). Para Arce la función de las tropas de la Notita sería la defensa marítima y fluvial en la retaguardia, de control de pasos montañosos y supervisión de caminos (Arce, 1982, 69).

Balil ha estudiado detenidamente el cambio de estrategia militar y sus consecuencias en la fortificación de ciudades (Balil, 1956, 1963, 1960 y 1970). Encuentra elementos característicos como son la multiplicación de torres debido al mayor uso de las ballistae, la abundancia de aspilleras en torres y muros para evitar los ángulos muertos, (Balil, 1956, 283; Balil, 1960 , 183-4), así como la pervivencia en nuestro país del opus cuadratum, desaparecido en Italia desde el I d.C. (Balil, 1963, 295). Este autor considera que desde el punto de vista de la técnica constructiva pueden distinguirse dos grupos: por un lado las ciudades fortificadas como Iruña; por otro los campamentos militares como León, Astorga, y Lugo, con muchos paralelos en la Galia (Balil, 1963, 294). Estas últimas siguen el modelo de sistemas defensivos de época de los Antoninos y Severos (Balil, 1960, 184). Probablemente sería León el primer núcleo en fortificarse, exportando su morfología militar a los demás (Richmond, 1930, 99-100).

En los últimos años, gracias a la sistemática labor de C. Fernández Ochoa, hemos tenido conocimiento de la existencia de un nuevo recinto fortificado tardorromano (Fernández Ochoa, 1984, 1986 y 1986-7, entre otros). Nos referimos a Gijón, cuya identificación en las fuentes aún no ha podido ser establecida con exactitud. La muralla descubierta, de considerable envergadura constructiva, resulta muy parecida a otros encintados del norte peninsular mejor conservados. Sin embargo no hay un solo dato que nos pueda hacer pensar en un carácter militar similar a Lugo, Astorga o León. De ahí que hayamos prescindido de su estudio, aunque su morfología y coincidencia cronológica no dejen de plantear interesantes cuestiones.

\section{- Castra Legionis VII Geminae}

La primera descripción moderna del recinto murado corresponde a Gómez Moreno (1925, 20), pero hasta Richmond no se realiza un estudio científico (Richmond, 1930, 91-94). Balil la incluye en su trabajo en 1960 (Balil, 1960, 192-3). García y Bellido es sin duda quien ha prestado mayor atención a este recinto, realizando las primeras excavaciones arqueológicas, que han respondido a algunas cuestiones pero han planteado otras nuevas (García y Bellido, 1968, 9-16; García y Bellido, 1968 b, s/p; García y Bellido, 1970, 571-575). Algún valor tienen para nosotros los trabajos de Mateo Marcos (Mateo Marcos, 1978 y 1981, 14-5) y Matilla Vicente (Matilla Vicente, 1983).

La presencia de la Legio VII Gemina en Hispania durante el Bajo Imperio está testimoniada por la Notitia (XLII, 1,25). No hay ningún motivo para dudar la continuidad de su estancia en León, bien testimoniada por las fuentes y la epigrafía. Las cannabae de la legión se convierten en ciudad desde mediados del siglo III, momento en el que está documentada la pre- 
sencia de magistrados (García y Bellido, 1968 b, s/p). Mateo Marcos sitúa sin argumento visible dichas cannabae al sur del recinto (Mateo Marcos, 1981, 14).

El recinto de la antigua Legio se asienta en una colina a orillas del Bernesga, poco antes de su confluencia con el Torio, cuyo punto más alto se halla en la plaza de la catedral, al este de la ciudad. Tiene forma rectangular con esquinas oblongas y ejes de $570 \times 350$, ocupando 20 has. Las murallas presentan un espesor de 5, 25 metros y una altura de 5, 5 metros. Están reforzadas con 31 torres semicirculares de $8,25 \mathrm{mtrs}$. de diámetro, separadas por lienzos de 15 mtrs (Balil, 1960, 192). La reconstrucción ofrece un número de torres entre 74 y 78 (Richmond, 1930, 91-93). No se conserva ninguna puerta.

Las excavaciones de García y Bellido revelaron que estaban constituídas por dos muros adosados con núcleo de hormigón: un pequeño muro de 1,80 metros con aparejo de sillares bien escuadrados y con juntas encintadas, y un segundo muro que envuelve el anterior por la cara externa con un aparejo de piedras mal labradas, de mucha peor calidad, hasta completar los 5,25 metros (García y Bellido, 1968, 13-15). Ambas presentan núcleo de hormigón. García y Bellido encuentra chocante que un muro tan cuidado se tape con otro de peor aspecto. Parece claro que el más estrecho es anterior. Por otra parte un muro de 1,80 metros no tendría ninguna utilidad defensiva. Cabría imaginarse un primer recinto de finales del III o comienzos del IV, que ante las amenazas de las invasiones de finales del IV se reforzara rápodamente con otro, construído en buena parte con materiales reutilizados. Como hipótesis plantea que un campamento elevado en una región hacia tiempo pacificada podría conformarse perfectamente con una pequeña muralla perimetral. Esta es la única indicación cronológica que ofrece García y Bellido para datar el recinto (García y Bellido, 1968, 15-6). Por otro lado la aparición de una atarjea con tégulas con el sello legionario al que le falta el apelativo de "Felix», ganado por la legión durante su estancia en el Rin, le da pie para pensar que el campamento pudo ser erigido por una vexilatio de la legión antes del 74, fecha de asentamiento definitivo de la misma en este lugar (García y Bellido, 1968, 30).

Persiste la duda sobre si la muralla se construye porque es un asentamiento de carácter militar, o por su condición posterior de ciudad civil.

\section{- Lucus Augusti}

Su recinto murado ha sido estudiado sucesivamente por Mélida (Mélida, 1921), Richmond (Richmond, 1930), Vázquez Seijas (Vázquez Seijas, 1955), Arias Vilas (Arias Vilas, 1972) y De Abel Vilela (De Abel Vilela, 1975), entre otros. No se han realizado excavaciones y en realidad la obra de Arias es el primer trabajo que aborda el tema desde el punto de vista arqueológico y militar, si exceptuamos el intento de Richmond, muy avanzado para su época.

También aparece citado en la Notitia Dignitatum como asiento de la Cohors Lucensis (XLII, 1, 29). Presenta un perímetro cuadrangular de 2120-40 metros, que comprende 28 has, con ángulos redondeados, adaptado al terreno y por ello no totalmente regular. El aparejo consta de dos paramentos, el interior realizado con pizarra y el exterior con lajas del mismo material, mezcladas con otros elementos, unidos con tierra o una especie de argamasa. Relleno a base de piedras de distintos tamaños, guijarros y tierra. En algunas zonas, sobre todo en las puertas aparecen sillares de granito bien escuadrados y dispuestos a soga y tizón, que de- 
bieron ser más numerosos pero han sido arrancados en muchos puntos (Arias, 1972, 53-55).

El muro está flanqueado por torres semicirculares, que debieron llegar a un total de $85 \mathrm{u}$ 86. más numerosas que en León, dada la diferencia de longitud del perímetro. Su diámetro varía entre 10, 15 y 13,40 mtrs (Richmond, 1930, 88). El tamaño de los intervalos no es constante. Se conservan restos del cuerpo alto en una de las torres, con dos ventanas en un piso, pero los testimonios hablan de dos pisos con cuatro ventanas en cada uno. Desconocemos cómo se realizarían las cubriciones y los accesos a las mismas (Arias Vilas, 1972, 56-7).

De las puertas actuales sólo 4 parecen romanas y éntre ellas la puerta Miñá es la única que conserva su carácter primitivo. Está flanqueada por dos amplias torres semicirculares de siIlares graníticos a soga y tizón. La cortina donde se encuentra la puerta, muy estrecha, está bastante retranqueada respecto a las torres que la flanquean. Encima se colocaría la maquinaria del rastrillo y estaría el pasillo que continuaba camino de ronda (Arias Vilas, 1972, 58-60).

Una excavación de urgencia ha revelado que la brevedad de sus cimientos a base de una hilada de cantos rodados y lajas de pizarra en sentido vertical sobre una capa de grijo (Arias Vilas, 1972, 9), impide la presencia de foso. Tal hecho coincide con la opinión de Grenier respecto a las ciudades bajoimperiales (Grenier, 1931, 403 y ss).

Arias data su elevación entre el 260 y el 310, tanto por los materiales reutilizados, como por sus paralelos con otros recintos del momento (Arias Vilas, 1972,113). Richmond, atendiendo sólo a los materiales epigráficos le daba una fecha parecida (Richmond, 1930, 90).

\section{- Asturica Augusta}

Las murallas de Astorga plantean muchos más problemas que las de León o Lugo. Se conserva una parte mucho menor, están más alteradas durante la época medieval, y no aparecen citadas en la Notitia como recinto militar. Muy pocos estudiosos se han ocupado de ellas. Richmond, sin estudiarlas detenidamente les de una cronología bajoimperial, del segundo cuarto del siglo III (Richmond, 1930, 90-1). Luengo las describe con núcleo de hormigón y careadas con sillares. Da además la noticia de la existencia de una torre cuadrada con grandes sillares en la base detrás del convento de San Francisco, que quedó oculta (Luengo, 1961, 153 y 155). La excavación practicada por Mañanes en la brecha abierta en 1809 por los franceses para penetrar en la ciudad, conocida como Puerta de Hierro, revelaron por primera vez la fase de la muralla auténticamente romana (Mañanes, 1976, 81-2). Quedaron al descubierto los cimientos de granito de una puerta flanqueada por dos cubos semicirculares, algo peraltados, de 8 metros de diámetro. Dentro del muro medieval de 5, $30 \mathrm{mtrs}$. se aprecia otro anterior, de 3,7 mtrs., seguramente el bajorromano, construído en hormigón muy compacto de color ocre claro, con un paramento exterior de opus incertum situado sobre los bloques graníticos que forman el cubo este de la puerta (Mañanes, 1976, 82; Mañanes, 1985, 209-11). Los cubos de la muralla medieval, semicirculares, deben responder a la forma original de las torres romanas.

Mañanes no añade nada nuevo a la cronología propuesta por Richmond y su excavación plantea importantes dudas (Mañanes, 1985, 209-11). 


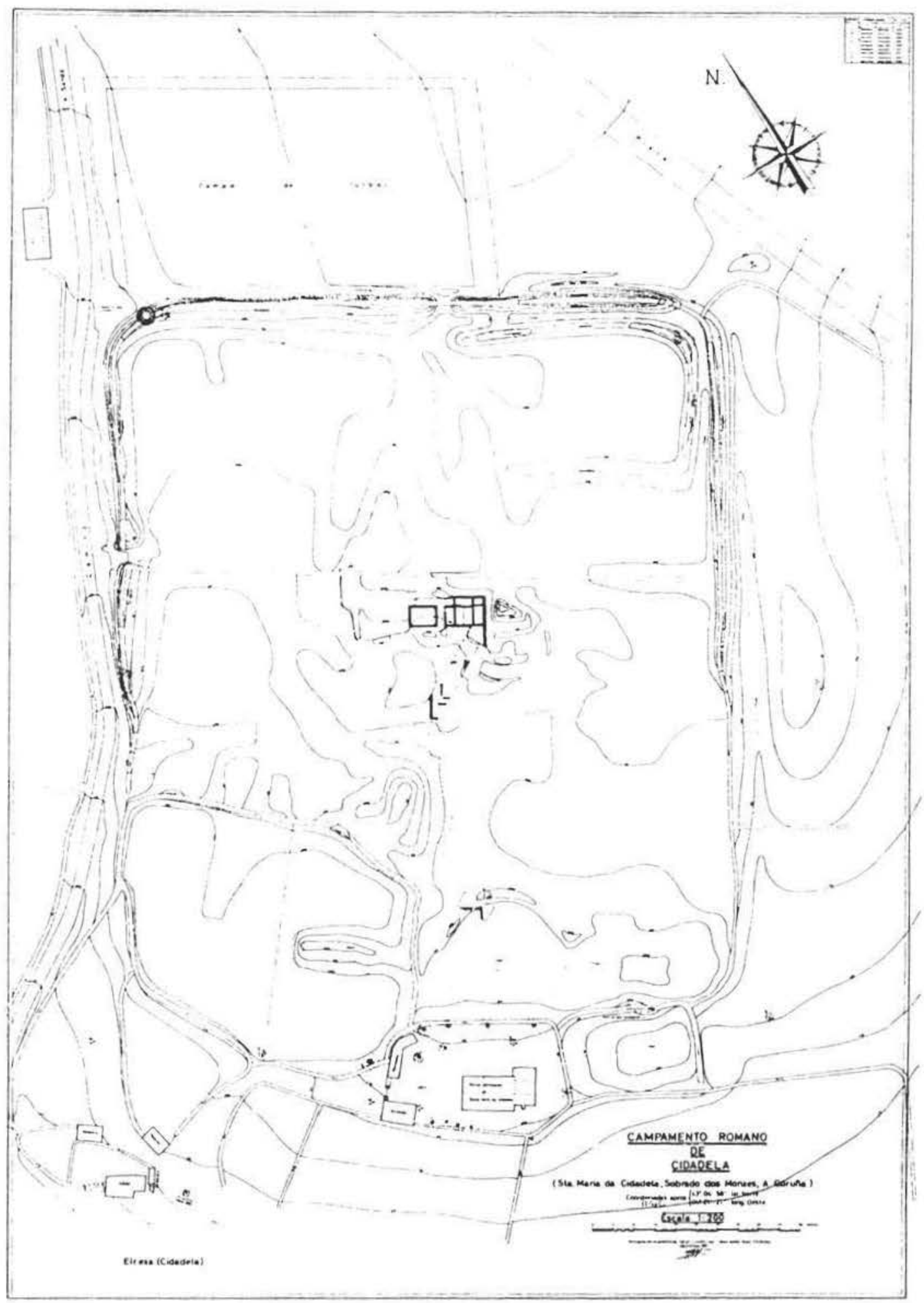

Figura 10.- Planta del campamento de A Cidadela, La Coruña (Caamaño Gesto. 1984). 
Recogemos aquí este recinto porque es normalmente identificado como Veleia, asiento de la Cohors I Gallica en la Notitia Dignitatum (XLII, 1, 32). Las excavaciones han revelado un recinto fortificado excepcional, pero no tenemos ningún dato que hable de un carácter militar. Fue explorado por Nieto Gallo en 1958 (Nieto, 1958).

La muralla presenta dos sectores constructivos diferenciados desde el punto de vista de su aparejo: uno a base de sillares de los que se conservan cuatro hiladas, y otro a base de lajas unidas con una gruesa capa de argamasa. El relleno a base de lajas y mortero es común a ambos sectores. La anchura de la misma varía entre 4 y 5, 40 mtrs. En algunos puntos conserva 8 mtrs. de altura, y debió llegar hasta los 12 (Nieto, 1958, 119-124, 130, 133-4). Presenta a la vez torres semicirculares y cuadradas, hecho no muy común dentro del panorama de las fortificaciones peninsulares. La puerta aparece flanqueada por dos torres semicirculares (Nieto, 1958, 138-40).

La cronología se fija a finales del III por las características constructivas y los hallazgos materiales bajo los cimientos. Se abandona con posterioridad al 350 , ya que no aparecen elementos de datación más tardía (Nieto, 1958, 143-9). No puede asegurarse que sea Veleia (Nieto, 1958, 225), y como ya hemos dicho, tampoco su carácter militar.

Varios años más tarde Elorza, basándose únicamente en las excavaciones de Nieto, se muestra más atrevido al afirmar su condición militar y la identificación con Veleia (Elorza, 1972, 182 y 185-191). Retrasa la construcción de la muralla hasta los primeros años del siglo IV (Elorza, 1972, 193).

\section{CONCLUSIONES}

La cuestión de los campamentos romanos en España ha levantando mucho interés en los últimos años, pero continúa planteando numerosas cuestiones. Uno de los temas menos conocidos y estudiados es el de las fortificaciones, tal vez por la patente carencia de datos, a diferencia de lo que ocurre en otros paises como Alemania y Gran Bretaña.

Tenemos un buen número de referencias específicas sobre elementos defensivos de los campamentos. La existencia y el proceso de construcción de fosos, terraplenes, empalizadas, muros, torres, y puertas está bien testimoniada en Polibio, Higinio, Vegecio y César. Sin embargo la mayoría de los datos corresponden a campamentos temporales, de madera. Los recintos de piedra apenas citados en las fuentes, lo que supone un perjuicio considerable.

Las excavaciones llevadas a cabo en campamentos británicos y continentales han confirmado la existencia de estas fortificaciones tanto en recintos de madera como de piedra. De hecho podríamos suponer que no existieron diferencias apreciables entre unos y otros, por lo menos a partir del siglo I d.C., que corresponde a la estabilización de las fronteras y a los asentamientos militares permanentes.

La investigación española sobre esta cuestión se encuentra muy retrasada. Carecemos de trabajos específicos sobre defensas castrenses. Pocos recintos de este tipo han sido excavados, y aún menos satisfactoriamente. La mayor parte de las publicaciones tratan el tema diametralmente, desde el punto de vista de su localización, o dentro de obras más generales. Tenemos 
que destacar la importante figura de Schulten, investigador alemán cuyos trabajos abrieron el camino a los estudios posteriores aunque, como ya hemos señalado, no tuvo continuadores directos.

Sin negar el indiscutible valor de las informaciones obtenidas por este historiador en sus escavaciones de Numancia, Renieblas o Cáceres el Viejo, y su recopilación de noticias sobre otros establecimientos de este tipo en toda España, sus trabajos plantean diversos problemas. Nunca excavó metodológicamente, teniendo en cuenta las estratigrafías, con lo cual perdió muchos datos cronológicos cuya reinterpretación hubiera sido muy útil en nuestros días. Sus dataciones se basan en las indicaciones proporcionadas por las fuentes, en su mayoría indi-

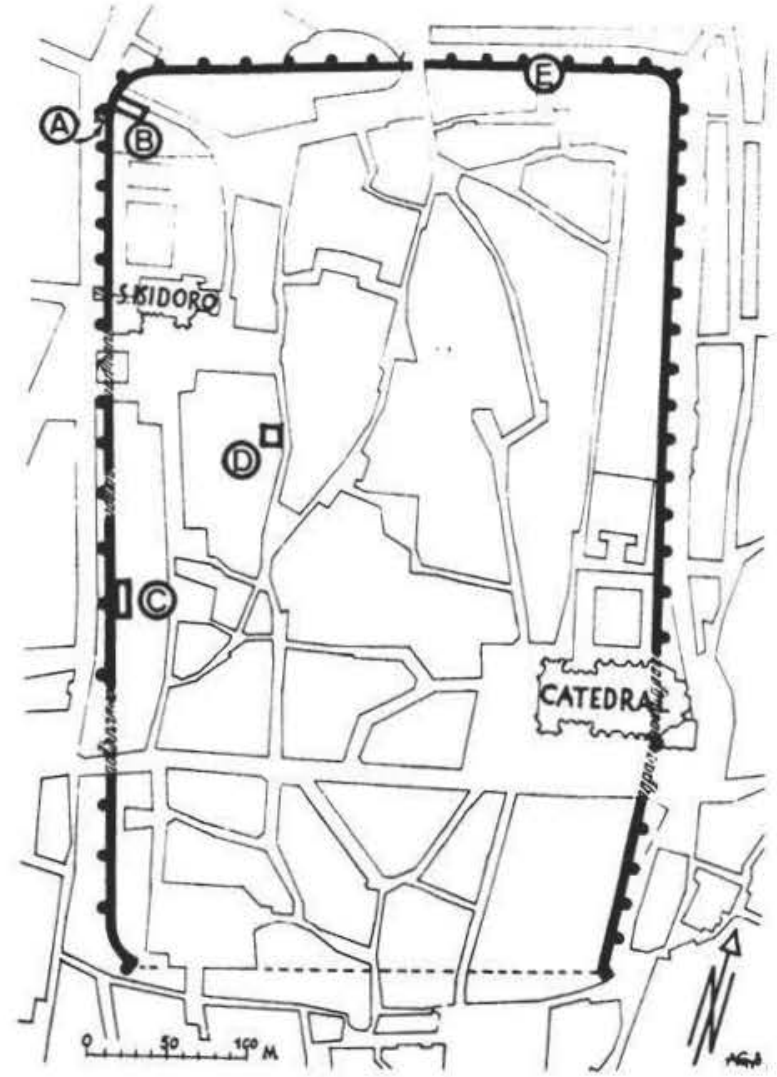

Figura 11.-Planta del recinto murado de León (García y Bellido, 1970).

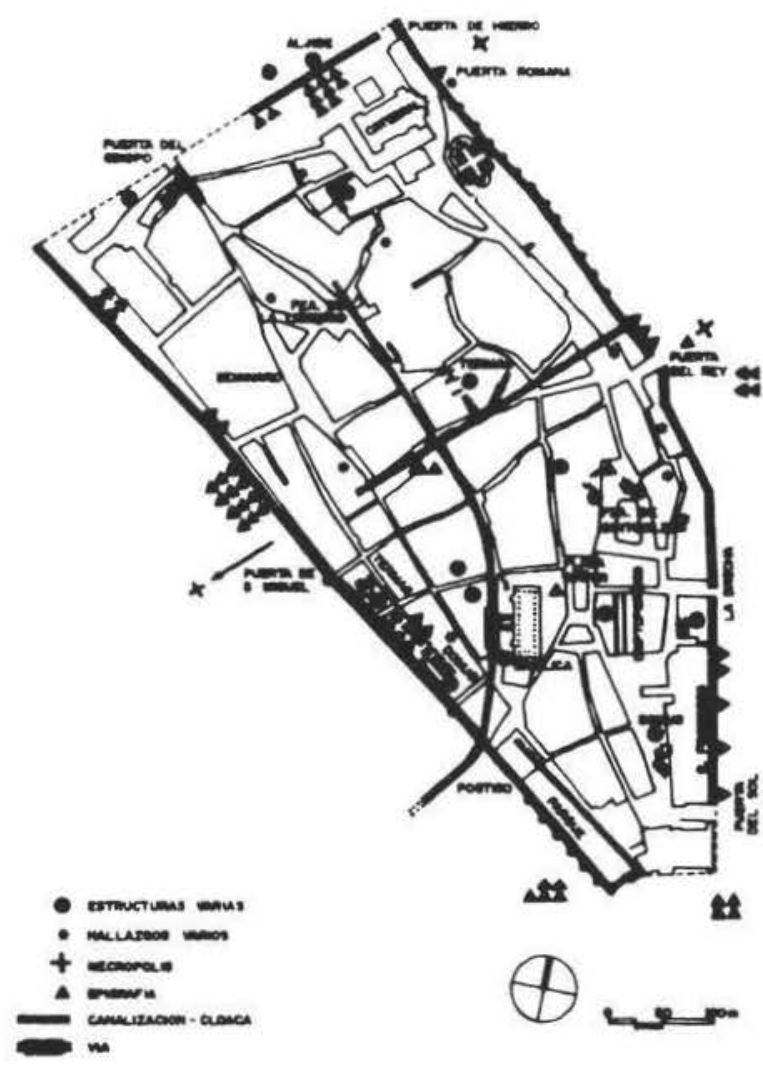

Figura 12.-Planta de Astorga romana, con distribución de hallazgos (Servicio Territorial de León, Junta de Castilla y León, 1990).

rectas. Respecto a sus publicaciones, aparecieron primero en alemán, y fueron traducidas al español bastantes años después. Publicó bastante pero repitiéndose con mucha frecuencia. Casi nunca cita bibliografía.

Ultimamente se tiende a una revalorización de Schulten. Los escasos datos estratigráficos modernos de lugares como Almazán o Cáceres el Viejo confirman las cronologías «históricas» propuestas por el investigador alemán. Aún así sigue siendo necesaria la reexcavación de los yacimientos donde trabajó.

Existen notables diferencias entre los campamentos republicanos e imperiales, en lo que 
respecta a su conocimiento. Los únicos campamentos estudiados con cierta extensión y publicados, Numancia, Renieblas y Cáceres se fechan en tiempos de la República. Los primeros fueron excavados por Schulten a comienzos del siglo. Cáceres lo fue a principios de la década de los treinta y ha sido reinterpretado recientemente por Ulbert. En general los republicanos se conocen antes, gracias sobre todo a Schulten. Ningún campamento imperial ha sido excavado con cierta extensión.

No podemos hablar de un único motivo que explique esta diferencia. La casualidad ha jugado un papel no desdeñable, pero la búsqueda, con las fuentes en la mano, realizada por Schulten tenía que llevar inevitablemente a la localización de los que aparecen citados en dichos textos, esto es, los campamentos del tiempo de la conquista. El interés por las ciudades «mártires», símbolo de los "grandes valores hispánicos» tuvo importancia en el comienzo de los trabajos en Numanica. Otro aspecto a tener en cuenta es la mayor abundancia de campamentos durante los siglos II-I a.C., que a lo largo de los cuatro siglos siguientes, época pacífica, con fronteras consolidadas. Muchos de los supuestos campamentos imperiales son en la actualidad ciudades, muy modificadas desde la época romana, y de difícil constatación arqueológica.

La diferencia entre campamentos republicanos e imperiales se observa también en los distintos métodos de identificación. Los primeros se buscan primero en los textos y se localizan prospectando la zona indicada; en el caso de los imperiales, más o menos casualmente se localiza el recinto, que no se cita en las fuentes, y se intenta identificarlo mediante la arqueología y la epigrafía. De ahí la gran atención que han prestado algunos historiadores y arqueólogos a las unidades militares que estuvieron en Hispania en una u otra época. Los datos referentes a la filiación militar son los únicos que se conservan en las lápidas funerarias, y de ellos pueden extraerse conclusiones importantes. Durante las últimas décadas no podemos desestimar la trascendencia de la fotografía aérea para localizar recintos como Castrocalbón, el segundo campamento de Rosinos de Vidriales, o Valdemeda.

Dentro de los imperiales tenemos que hacer una excepción con los campamentos augusteos y tiberianos, que han sido objeto de una gran polémica historiográfica sobre su localización dentro de los textos antiguos, cuestión muy ligada a las investigaciones sobre las Guerras Cántabras y los métodos de implantación del ejército en el territorio del Noroeste. Igual podemos decir de Ampurias y Tarraco, objeto de excavaciones continuadas desde la década de los cuarenta, aunque no específicamente por su condición militar.

Sin embargo el análisis de la técnica constructiva demuestra que no existen grandes diferencias. La mayor parte de los campamentos, tanto republicanos como imperiales utilizan el mismo aparejo, aunque varían respecto a su regularidad. El sillarejo es el más común dentro de los campamentos republicanos. Aguilar de Anguita, el Castillejo, Peña Redonda, La Dehesilla, Almazán, Renieblas III y IV utilizan esta técnica, que reaparece en algunas ciudades tardorromanas. La mayor parte de los recintos altoimperiales (Rosinos I y II, Cidadela, Aquis Querquenis) utilizan sillares bien escuadrados, a soga y tizón. Algunos campamentos republicanos como Tarraco, Ampurias, El Castillejo, Renieblas V y Castra Caecilia emplean este mismo aparejo. En general no podemos hablar de una correspondencia perfecta entre una época y una técnica constructiva determinada.

Ninguno de los establecimientos militares conocidos presenta muros macizos. Se utiliza la técnica constructiva denominada emplecton, consistente en dos muros paralelos con un relle- 
no en su interior. Sólo en algunos campamentos imperiales este último es de hormigón (Rosinos I y II). En el resto (Tarraco, Aguilar de Anguita, El Castillejo, Peña Redonda, Dehesilla, Renieblas III, Almazán, Cáceres el Viejo, Aquis Querquenis) se realiza a base de guijarros, piedras más o menos grandes, arcilla, y materiales que dependen de la litología de la zona.

No se aprecia mucha variedad en cuanto al grosor de los muros. Se agrupan en torno a dos grupos: uno con murallas de aproximadamente 2 metros de anchura (Agular, Renieblas II, Rosinos II, y Castrocalbón), y otro entre 4 y 6 mtrs (El Castillejo, Dehesilla, Renieblas III, Renieblas V, Cáceres, Aquis Querquenis). Este último es el más frecuente, Mención especial merece $\mathrm{A}$ Cidadela con una muralla de tan solo 1 metro de grosor. No existe una correspondencia entre la cronología y la anchura, que parece una variable dependiente de las necesidades de cada uno de ellos.

Pueden establecerse también varios grupos de recintos en cuanto a su extensión. Entre 4 y 6 has. miden los de El Castillejo, Peña Redonda, Almazán, Rosinos II, Valdemeda. Aguilar de Anguita, La Dehesilla y Rosinos I se enmarcan entre 12 y 16 has.

En cuanto a la forma, sí podemos observar una distinción clara entre campamentos republicanos e imperiales. Los primeros adoptan perímetros irregulares (Tarraco, Almenara, Aguilar, El Castillejo, Peña Redonda, Dehesilla, Alpanseque, Renieblas I y Renieblas II) o cuadrangulares (Renieblas III, Renieblas V). Como característica a tener en cuenta ninguno de ellos tiene el perímetro completamente cuadrado, ya que se adaptan al terreno. Los imperiales son rectangulares (Rosinos I y II, Valdemeda, Castrocalbón, Cidadela y Aquis Querquenis). Precedentes de estos últimos parecen los de Almazán y Cáceres el Viejo, éste con esquinas en ángulo agudo.

Mayor variedad observamos entre los elementos puramente defensivos. La presencia de torres parece exclusiva de época republicana aunque reaparece en los encintados bajoimperiales. Su planta es exclusivamente cuadrada o rectangular (ejemplos de Tarraco, Almenara, Aguilar de Anguita, Castillejo y Renieblas III entre otros). A excepción de Aquis Querquenis carecemos de torres en campamentos altoimperiales, donde siempre se cumplen unas reglas canónicas.

Las torres de vigilancia extramuros no han sido bien constatadas en ningún recinto, pero se ha supuesto su existencia en Valdemeda, Castrocalbón, Cáceres el Viejo y Cidadela.

Conocemos fosos en Peña Redonda, Almazán, Valdemeda, Cidadela, Aquis Querquenis, y quizás en Navalcaballo. En Castra Caecilia se documentan dos, separados por varios metros.

Las puertas están bien constatadas en casi todos los recintos. Suelen estar flanqueadas por dos torres, normalmente cuadrangulares, como en Almenara, Castillejo, Peña Redonda y Renieblas III. Poternas se conservan en Tarraco. Están documentados otros tipos de entrada, muy comunes fuera de nuestro país. En Almazán y posiblemente en Cáceres el Viejo aparecen ejemplos de tituli o defensa adelantada. En Aguilar, Peña Redonda y posiblemente en Valdemeda se encuentran puertas desencajadas. Estas defensas especiales sólo aparecen en recintos de momentos muy activos militarmente.

Se conservan contados restos de los elementos superiores de las murallas. En Tarraco se conserva el piso de una cámara de la Torre de la Minerva. En Aquis Querquenis se encontró un sillar redondeado que para el autor pertenecía al coronamiento.

No sabemos nada concreto sobre los campamentos augusteos. Los supuestos recintos de Sasamón, Herrera, Astorga y Lugo no están constatados. Igual podemos decir de Pompaelo. 
Un grupo completamente distinto lo constituyen las ciudades amuralladas tardorromanas, en las que se ha creido ver una función militar a partir de la técnica constructiva y las noticias de la Notitia Dignitatum. Nos referimos a León, Lugo, Astorga e Iruña. Las funciones civiles y militares están tan ligadas que resulta muy difícil pronunciarse sobre el tema. En todo caso no son típicos recintos campamentales. Su extensión es bastante mayor que la de los campamentos republicanos e imperiales. Lugo mide 28 has. y León, 20 has. Este hecho resulta lógico si pensamos que son núcleos urbanos. El perímetro adopta formas diversas, que varían desde la cuadrangular de Lugo, hasta la irregular de Iruña y la trapezoidal de Astorga. León es el único ejemplo que guarda la morfología típica de un recinto imperial, rectangular con esquinas oblongas, sin duda por la pervivencia del asentamiento militar anterior.

Los encintados son por regla general más anchos que en épocas anteriores, de cerca de 5 mtrs (León, Lugo, Iruña), y en todo caso mayor de 4 mtrs. (Astorga). Utilizan el sistema de muros paralelos rellenos con guijarros (Lugo, Iruña) o con núcleo de hormigón (León y Astorga). El aparejo exterior puede ser a base de sillares (León y Astorga) o sillarejo (Iruña, Lugo). Los sistemas constructivos de las dos ciudades astures parecen de mejor calidad que los de Lugo e Iruña.

Torres y puertas presentan notables diferencias respecto al grupo de fortificaciones militares anteriores. En los cuatro aparecen numerosas torres de tipo semicircular, desconocidas dentro del programa constructivo castrense, aunque tampoco faltan las cuadrangulares (Asturica, Iruña). Quizá en León también eran de este tipo, aunque no se han conservado. Lugo es el único recinto donde se conserva parte de la habitación șuperior de una torre.

Respecto a la localización geográfica existen grandes diferencias entre campamentos republicanos, altoimperiales y ciudades bajoimperiales. Los motivos estratégicos del asentamiento varían radicalmente. Los republicanos no se enmarcan dentro de una «gran» estrategia como sucede con Augusto y sus sucesores, sino que responde más bien a necesidades concretas en momentos puntuales, normalmente al compás de los sucesivos enfrentamientos bélicos. Se concentran en la Celtiberia y en la Lusitania, zonas de gran actividad militar. Desde el final de las Guerras Cántabras se inaugura una política imperial completamente distinta. La estabilización de fronteras lleva a la instalación de asentamientos militares en zonas estratégicas del Imperio, de forma más o menos definitiva. La consecuencia más importante será la petrificación de los campamentos.

La sedentarización de los recintos militares está bien documentada en nuestro país, si bien la reorganización definitiva no tiene lugar hasta la época de los Flavios. Los campamentos de las legiones dejadas en la Península como guarnición tras la conquista del Norte cambian alguna vez de emplazamiento. Conocemos poco de los movimientos de tropas peninsulares entre Augusto y Tiberio. En época de éste es posible que la Legio IV se traslade de lugar, y encontramos otras dos legiones (VI Victrix y X Gemina) asentadas en la región astur. Durante el reinado de Caligula o Claudio la legión IV abandona la región cántabra y se traslada a Germania. El motivo de que sea ésta y no alguna de las otras dos la que salga de la Península hay que buscarlo en el menor interés estratégico y económico de la zona de asentamiento. Las dos legiones astures debían cumplir un papel más importante desde el punto de vista económico, que tendría que ver con las actividades mineras (Roldán, 1974, 183-4). La marcha de estas legiones y su inmediata sutitución por la VII Gémina, junto con varias unidades auxiliares, indica de àlgún modo la continuidad de una política ya emprendida y continuada durante más 
de cien años. Junto a las funciones de supervisión de la actividad minera, de algún modo testimoniado en el campamento de Valdemeda, tendrían otras específicamente militares, como el control y conservación de la red de comunicaciones.

El Bajo Imperio coincide con un cambio de la estrategia general en cuanto a fortificacines militares. La función civil y militar se combina en algunos núcleos urbanos como Lugo, León y Astorga. Las murallas de éstas y otras ciudades no se elevan a nuestro entender por temor directo a una invasión, sino debido a un cambio en la política estratégica del gobierno central, profundamente militarista, que tiene mucho que ver con la división del ejército en limitanei y comitatenses, y la defensa en profundidad. Una opinión similar fue expresada por Roblin en 1965 (Roblin, 1965, 369). La función no sería tanto la defensa costera en retaguardia como el mantenimiento de las vías de comunicación en buen uso y vigiladas para el buen funcionamiento de la annona militaris. La conservación de vías, la organización del transporte, la protección contra el bandidaje entrarían dentro de sus atribuciones. Las ciudades amuralladas pueden reflejar técnicas constructivas militares, ya que posiblemente serían estos los encargados de planificarlas y ejecutarlas. No podemos incluirlas dentro del mismo grupo que los campamentos porque su carácter militar resulta, cuando meno, discutible.

Encontramos bastantes problemas y cuestiones aún no contestadas. La cronología sigue siendo en la mayoría de los casos aproximada, obtenida por comparación con otros recintos. Los criterios de localización, aun comprendidos en términos generales, no son evaluados en

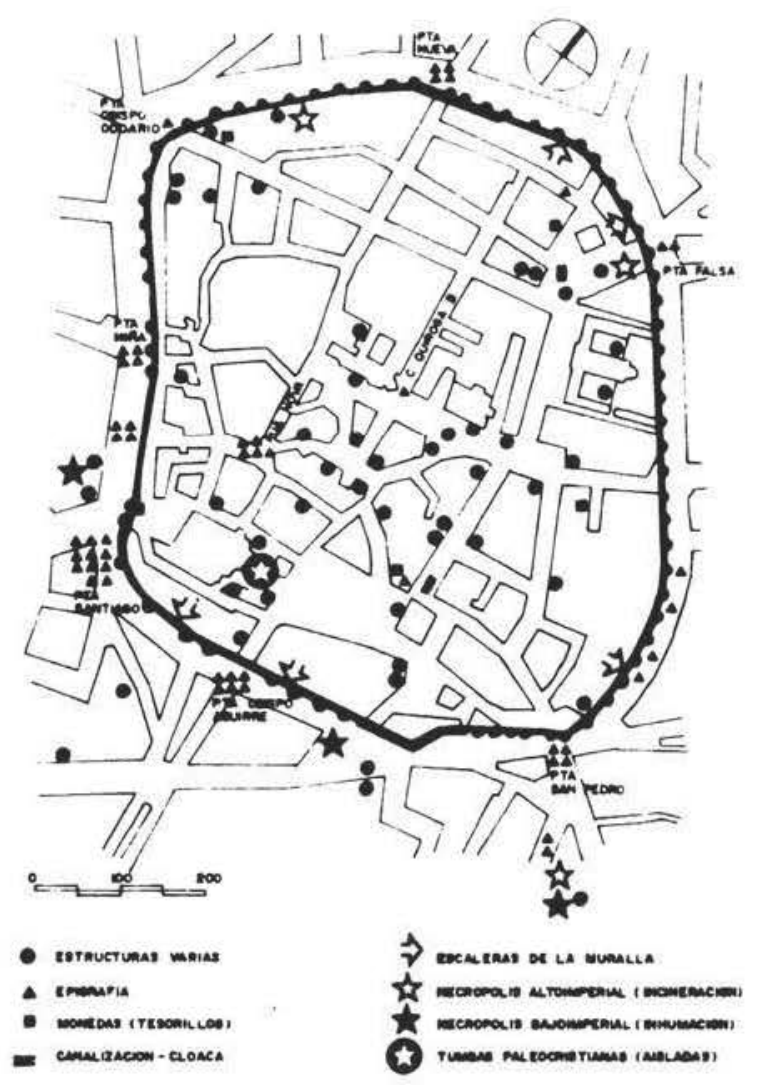

Figura 13.-Planta de Lugo con distribución de hallazgos romanos (Arias Vilas, 1990). 
su totalidad. La delimitación del carácter militar de las ciudades fortificadas bajoimperiales aún está pendiente. Igual podemos decir de la relación entre un campamento y la ciudad surgida de sus cannabae, sobre lo que se insiste mucho actualmente. En León. Ampurias y Tarraco está bien testimoniada la continuidad urbana posterior, pero por el momento no podemos pronunciarnos sobre los recintos precedentes. En el primero de estos núcleos no está nada clara la posición de las cannabae ni el momento en que se integran en el recinto militar. En cualquier caso no siempre tiene porqué obedecer a una política planificada y seguida generalmente.

Seguimos desconociendo la mayor parte de las fortificaciones campamentales, a pesar de los tímidos avances en el tema. Las mejores conocidas siguen siendo las ciudades bajoimperiales. Por otro lado hemos de señalar que los datos recogidos en nuestro país, uno de los mejores campos para conocer los campamentos de época republicana, contradicen los datos defensivos de Polibio. Aún no tenemos restos de campamentos en madera, pero son muy abundantes los de piedra. No sabemos si esta disparidad obedece a una característica peculiar de nuestro país, o sería una costumbre mucho más extendida de lo que los datos del historiador griego permiten suponer.

Otra cuestión hasta el momento no aclarada es la de los campamentos augusteos establecidos para la conquista de Cantabria y Asturias. Sin entrar en el problema de su localización, lo que podemos constatar es que no ha aparecido resto alguno de campamento en piedra, a excepción del primer recinto de Rosinos. Quizá este hecho indique que tales campamentos nunca fueron de este material, sino de madera, y de ahí las dificultades de identificación. Tal característica no sería extraña en este momento cronológico. Sabemos que todos los campamentos del limes se construyen en madera y no comienzan a petrificarse al menos hasta la segunda mitad de I d.C. Pero por otra parte no deja de llamarnos la atención el hecho de encontrar campamentos republicanos en piedra construídos para campañas más cortas que las del 26-19 a.C., mientras éstos sólo son de madera. Es posible que a finales del siglo I a.C., la pacificación peninsular lo hiciera ya superficial. Otra posibilidad es que nunca llegaran a adoptar una estructura castrense canónica.

Un problema similar nos plantea el recinto de León, sin huellas de fortificaciones anteriores al siglo III. Debemos suponer que las primeras defensas fueron de madera y se petrificaron tardíamente. El primer amurallamiento de 1,80 mtrs. constatado por García y Bellido, sigue planteando cuestiones relacionadas con su operatividad táctica, pero hemos encontrado un paralelo en A Cidadela aún más pequeño, de 1 mtrs., lo que me hace especular con el hecho de que no debía ser una práctica tan extraña en núcleos militarizados, al menos en la Península.

La respuesta a estas dudas sólo puede estar en la excavación sistemática de varios de estos asentamientos, aunque es muy posible que por nuestras circunstancias particulares, nunca podamos llegar al grado de conocimiento de otras regiones del Imperio, donde fueron mucho más numerosos. 


\section{BIBLIOGRAFÍA}

\section{Fuentes}

Apiano: Iheria.

César: De Bello Gallico.

César: De Bello Alexandrino.

César: De Bello Civile.

Dion Cassio: Historia Romana.

Flavio Josefo: Bellum ludaicum.

Floro: Epitome Gestae Romanae.

Frontino: Stragemata.

Higinio (o Pseudohignio): De Metatione Castrorum o De Munitionibus Castrorum (ed. Biblioteca Teubneriana, Leipzig, 1977).

Higinio: De Metatione Castrorum (ed. Lenoir, París, 1979).

Julio Africano: Cestes.

León el Filósofo: Institutiones Militares.

Orosio: Adversus paganos.

Plinio: Naturalis Historia (ed. Jones Loeb y V.V.A.A., Loeb Classical Library, Harvard, 1942).

Plutarco: Pyrrhus.

Plutarco: Sertorius.

Plutarco: Tiherius Graccus.

Polibio: Historias (ed. Manuel Balasch, Biblioteca Clás. Gredos, Madrid, 1981).

Salustio: Historiae.

Tito Livio: Ab Urbe Condita.

Tito Livio: Periochae.

Tolomeo: Geographia (ed. Carolus Fridericus Augustus Nobbe, Leipzig, 1881).

Vegecio: Epitome Rei Militari.

Vitrubio: De Architectura (ed. Agustín Blanco, Iberia, Barcelona, 1986).

\section{Análisis textual}

FABRICIUS, E. (1932): «Some notes on Polibius description of Roman camps», Journal of Roman Studies XXII, 78-87.

LENOIR, M. (1986): «Le camp romain et l'urbanisme hellénistique et romain». La fortification dans l'Histoire du Monde grec. Colloque Int, C.N.R.S., Valbonne, 1982, pub. París, 329-336, fig. 325-331.

MASQUELEZ, E. (1887): «Castra» en Daremberg-Saglio: Dictionnaire des antiquités grecques et romaines, I, París, 940-959.

SCHulten, A. (1935): Fontes Hispaniae Antiquae, III. Barcelona.

SCHUlten, A. (1937): Fontes Hispaniae Antiquae, IV. Barcelona.

SCHulten, A. (1940): Fontes Hispaniae Antiquae, V. Barcelona.

\section{Fortificaciones castrenses británicas}

BREezE, D. J., Dobson, B. (1969): «Fort-types on Hadrian's wall», Archaeologia Aeliana 47, 15 y ss. BREEZE, D. J. (1982): The Northern Frontiers of Roman Britain. London.

CRICKMORE, J. (1984): Romano-British defences, B.A.R. (British Series) 126.

DAVISON, D. P. (1989): The Barracks of the Roman Army from the 1st. to 34d. Centuries A.D., B.A.R. (Int. Series) 472 (I-III). 
HANSON. W. S. (1983): Rome's North-West Frontier. The Antonine Wall. Edimburg.

JOHNSON, A. (1983): Roman Forts, London.

JOHNSON, S. (1983): Late Roman Fortifications, London.

JONES, M. J. (1975): Roman Fort-defences to A. D. 117, with special reference to Britain, B.A.R. 21, Oxford.

LANDER. J. (1984): Roman Stone Fortifications, B.A.R. (Int. Series) 206.

ROBERTSON, A. S. (1979): The Antonine Wall, Glasgow (3. ${ }^{\text {a }}$ ed.).

WILSON, R. (1980): Roman Forts, London.

\section{Fortificaciones castrenses continentales}

CATANICIU, J. C. (1981): Evolution of the system of defence works in Roman Dacia, B.A.R. (Int. Series) 116.

GENSER, K. (1986): Des Osterreichische Donaulimes in der Römerzeit. Ein Forschungsbericht. Der romische Limes in Österreich (Österreichischen Akademie der Wissenschaften), Wien.

Johnson, A. (1987): Römische Kastelle, Mainz am Rheim, (ed. además de Johnson, 1983)

KANDLER, M y Vetters, M (1986): Der römische Limes in Österreich. Ein Führer, Wien.

SCORPAN, C. (1980): Limes Scythiae, B.A.R. (Int. Series) 88.

\section{Campamentos en España}

ABASCAL, J. M. (1986): «La Legio VII Gemina. Balance de la investigación y perspectivas», Actas I Congr. Int. Astorga romana, Astorga, 317-328.

ABasolo Álvarez, J. A. (1975): «Notas sobre el campamento romano de Sasamón (Burgos)», Pyrenae, 11, 127-132.

DE ABEL VILELA, A. (1975): Doscientos años de obras y restauraciones en la muralla de Lugo, Lugo.

Aguilera y Gamboa, E. (S/F): Páginas de la Historia Patria por mis excavaciones arqueológicas, Tomo III, 9.

AGUILERA Y GAMBOA, E. (1916): Las necrópolis ibéricas, Madrid, 83-85.

ALFOLDY, G. (1969): Fasti Hispanienses. Senatorische Reichesbeante und Offiziere in den Spanischen Provinzen des römischer Reiches von Augustus bis Diokletian, Wiesbaden, 115.

ALMAGRO BASCH, M. (1945): «Varia. Excavaciones de Ampurias: últimos hallazgos y resultados», A. E. Arq., 59-75.

ALMAGRO BASCH, M. (1947): «Estratigrafías de la ciudad helenístico-romana de Ampurias», A. E. Arq., 179-199.

ALmagro BASCH, M. (1951): Las fuentes escritas referentes a Ampurias. Monografias ampuritanas I, Barcelona, 72-3.

ALMAGRO BASCH, M. y Lamboglia, N. (1959): «La estratigrafía del documano A de Ampurias», Ampurias $X X I, 1-28$.

ALONSO SÁNCHEZ, A. (1985): «Los campamentos romanos como modelo de asentamiento militar: Cáceres el Viejo", Il Jornadas de Metodología y didáctica de la Historia: Prehistoria y Arqueología, 195-208.

ALONSO SÁNCHEZ, A. (1988): Fortificaciones romanas en Extremadura: la defensa del territorio, Salamanca.

AQUILUE, J. y V.V.A.A. (1984): El Forúm romà de Empuries, Barcelona.

ARIAS VILAS, F. (1982): La muralla de Lugo, Studia Arqueologica 14, Santiago.

ARIAS VILAS, F. (1976): «Acerca de la topografía romana de Lucus Augusti», Symp. Ciud. Augs. II, Zaragoza, 63-68. 
ARIAS VILAS, F. (1976 b): «Lucus Augusti», La romanización de Galicia. Seminario de Estudios cerámicos de Sargadelos, Coruña, 57-62.

ARIAS VILAS, F. (1981): La muralla romana de Lugo. Folleto turístico M. Cultura, Lugo.

ARIAS VILAS, F. (1984): «A cidade de Lucus Augusti», Portugalia IV-V (Actas do Coloquio Interuniversitario de arqueología do Noroeste), 209-214.

ARCE, J. (1980): «La "Notitia Dignitatum" et l'armée romaine dans la Diocesis Hispaniarum», Chiron 10, 593-608.

ARCE, J. (1982): El último siglo de la España romana (284-409), Madrid.

ARCE, J. (1986): «Notitia Dignitatum Occ. XLII y el ejército de la Hispania tardorromana». Ejército y sociedad. Cinco estudios sobre el mundo antiguo. Ed. A. Del Castillo, León, 51-62.

BALIL, A. (1958): «Los trabajos de fortificación en las provincias del Occidente romano después de la crisis del siglo III y su significación político-militar y social», Actas I Congreso Español de Estudios Clásicos, Madrid, 1956, 281-4.

BALIL, A. (1960): «La defensa de España en el Bajo Imperio», Zephyrus XI, 179-197.

BALIL, A. (1963): «Las fortificaciones del Bajo Imperio en las provincias romanas de España, Celticum $X I, 293-296$.

BALIL, A. (1964): «Urbanismo romano en la España Céltica». Celticum XII, 275-288.

BALIL, A. (1969): «Excavaciones en la Torre de Pilatos», Exc. Arq. Esp. 65.

BALIL, A. (1970): «La defensa de Hispania en el Bajo Imperio: Amenaza exterior e inquietud interna», Legio VII Gemina, León, 603-620.

BALIL, A. (1976): «Bracara Augusta y el Conventus Bracarus», La romanización de Galicia. Seminario Estudios Cerámicos de Sargadelos, La Coruña, 45-53.

BALIL, A. (1984): «Lucius Terentius, Alfarero de la legión IV Macedónica», Sautuola III, 171-3.

BALIL, A. (1986): «Varia de arqueología: terra sigillata aretina decorada de la Península Ibérica. II Valle del Duero", B.S.E.A.A. 52, 239-45.

BELTRÁN LLORIS, M. (1973-4): «Problemas de la arqueología cacereña: el campamento romano de Cáceres el Viejo (Cáceres). Estudio numismático». Numisma 23-4, 255-310.

BELTRÁn LLORIS, M. (1976): «La cerámica del campamento de Cáceres el Viejo (Cáceres)». Ponencias VII y VIII Arqueología y Arte Antiguo. V Congreso de Estudios Extremeños 3-22.

BELTRÁN MARTINEZ, A. (1965): Las murallas ciclópeas de Tarragona. Arquitectura megalítica y ciclópea catalano-balear, Barcelona.

Beltrán MARTineZ, A. (1967): «El problema de la muralla ciclópea de Tarragona», Caesaraugusta 28-30, 143-155.

BELTRÁN MARTINEZ, A. (1972): «Las investigaciones arqueológicas en Numanica», Crónica Coloquio Conmemorativo XXI Centenario de la Epopeya numantina, Zaragoza, 37-43.

BosCh GimperA, P. (1926): «Problemas d'Història Antiga: Arqueología tarragonines», Boletín Arqueológico 24-29, 125-130.

CAMAÑo Gesto, J. M. (1984): «Excavaciones en el campamento romano de Cidadela (Sobrado dos Monxes, Coruña), Not. Arq. Hisp. 18, 233-254.

CALAMA Y Rosellón, A. (1972): «La primera guerra celtibérica (en torno a la batalla del 23 de Agosto del año 153 a.C), Crónica Coloquio Conmemorativo del XXI Centenario de la Epopeya numantina, Zaragoza, 145-161.

Del Castillo, A. (1931): «Una minerva de bronce», Bol. Real Academia Gallega 20, 53.

DUPRE I RAVENTOS, X. (1988): El circ romá de Tarragona. I. Les Voltes de S. Ermenegild. Tarragona.

ELORZA, J. C. (1972): «A propósito de la muralla romana de Iruña (Alava)», Est. Arq. Alavesa 5, 183194.

FERNÁNDEZ GUERRA (1889): «Cáceres en tiempos de los romanos», R. E. I, 141.

FERNÁNDEZ IBAÑEZ, C. Y PÉREZ GONZÁLEZ, C. (1989): «Strigile romana procedente del yacimiento de «El Cuartel» (Herrera de Pisuerga, Palencia)», Actas II Congreso de Historia de Palencia, Palencia, 431-441. 
Fernandez-Possf. M. ${ }^{a}$ D. y Sánchez-Palencia, J. (1988): La Corona y el Castro de Corporales II. Campaña de 1983 y prospecciones en la Valdería y la Cabrera (León), Exc. Arq. Esp. 153, 148-9.

FERNANDEZ OCHOA, C. y V.V.A.A. (1984): "Excavaciones en la muralla romana de Cimadevilla», Gijön romano. Gijón, 63 y ss.

FERNANDEZ OCHOA, C. (1986): «Ultimos resultados de las excavaciones en la muralla de Cimadevilla (Gijón). Actas I Congreso Internacional Astorga romana. Astorga, 329 y ss.

FERNÁNDEZ OCHOA, C. (1986-7), «Gijón, fortaleza romana en el Cantábrico», C.P.A.U.A.M (Homenaje Prof. Gratiniano Nieto), II, pp. 185-203.

FICK, A. (1933): "Die stadtmauer von Tarragona». Archaologischer Anzeiger, 483-514 (en Jahrbuch des Deutschen Archaologischen Institus).

FiTA, F. (1891): «Hitos de la Legio IV Macedónica», B.R.A.H. 18, 457 y ss.

FITA, F. (1905): «Gijón», B.R.A.H. 46, 80-1.

FORNI, G. (1970): «L'occupazione militare romana della Spagna Nord-occidentale: analogie e paralleli», Legio VII Gemina. León, 205-226.

FUENTES DOMingueZ, A. (1989): La necrópolis tardorromana de Albalate de las Nogueras (Cuenca) y el problema de las denominadas "Necrópolis del Duero». Cuenca.

GAMER, G Y ORTEGO, T. (1970): «Nuevas observaciones sobre el campamento romano de Almazán (Soria)», Celtiberia 39, 67-79 (ed. en alemán en Mad. Mitt. 10, 1969, pp. 172-184).

GAMER, G. (1975): «Fragmente kolossaler Bronzastatuen aux dem römischers Militärlager bei Rosinos de Vidriales (prov. Zamora) und us Poza de la Sal (prov. Burgos), Madrider Mitteilungen 16, 277-8.

GARCíA Y BELLIDO, A. (1945): La arquitectura entre los iberos, Madrid, 1945, 37.

GarCía y Bellido, A. (1961): «El "Exercitus Hispanicus" desde Augusto a Vespasiano», A.E. Arq. 34, 114-160.

Garcia y Bellido, A. y V.V.A.A. (1962): Herrera de Pisuerga, Exc. Arq. Esp. 2, Madrid, 29-37.

GarCía Y BELlido, A. (1966): «Nuevos documentos militares de la Hispania romana», A. E. Arq. 39, 26-42.

GarCíA Y BELLIDO, A. (1968): «León y la legio VII Gemina con motivo del XIX Centenario de su creación", XIX Centenario Creación Legio VII Gemina. Programa General, León.

GARCiA Y BELLIDO, A. (1968): Nueve estudios sobre la Legio VII Gemina y su campamento en León. León. (repetido en «Estudios sobre la Legio VII Gemina y su campamento en León», Legio VII Gemina, León, 1970, 571-599).

GARCIA Y BELLIDO, A. (1969): «Esculturas romanas en Galicia». Cuadernos Estudios Gallegos 24, 32 33 , fig. 7-9.

GARCÍA Y BELLIDO, A. (1975): «El llamado Itinerario del Barro», B.R.A.H. 172, 547-563.

GARCíA Y BELLIDO, A. (1976): «El ejército romano en Hispania», A. E. Arq. 49, 59-101.

GARCíA DíAZ, R. (1945): «Hitos terminales del campamento de la legión IV Macedónica en Cantabria», A. E. Arq. 18, 82-86.

GARCíA Marcos, V. y Vidal Encinas J. M. (1990): «Excavaciones arqueológicas de urgencia: Astorga». Numantia III, 259-263.

GARCÍA ROMERO, C. (1909): «Una estación romana desconocida», B.R.A.G. 3, 11-13.

García Moreno, M. (1925): Catálogo monumental de España. Provincia de León. Madrid, 20.

García Moreno, M. (1927): Catálogo monumental de España. Provincia de Zamora, Madrid, 47-51.

GIMÉNEZ SOLER, A. (1921): Refutación a las teorías del Prof. Schulten referidas a Numancia. Discurso de apertura del curso académico de 1921-1922, en la Universidad de Zaragoza, Zaragoza, 4-68.

GÓMEZ SANTACRUZ, S. (1914): El solar numantino. Refutación a las conclusiones históricas y arqueológicas defendidas por Adolf Shculten, Madrid.

GÓMEZ SANTACRUZ, S. (1935): Numancia. Sus guerras. Exploración de sus ruinas. El Museo Numantino, Soria.

GonZÁlez ECHEgaRaY, J. (1966): Los Cántabros, Santander.

GonZÁlez Echegaray, J. (1975): «La Legio IV Macedonica en España», Hisp. Ant. V, 151-203. 
GonzÁlez Echegaray, J. (1977): Cantahria a través de su historia. Santander, pp. 81 y ss.

GRENIER, A. (1931): Matuel d'archeologie prehistorique celtique el gallo-romaine V, París, 403 y ss.

HAuSCHILD, T. (1973-4): «La puerta romana de la muralla de Tarragona», Bol Arq. 121-8, 23-34.

HAUSCHILD, T. (1975): «Die romische Stadtmauer von Tarragona», M. M. 16, 206-237.

HAUSCHILD, T. (1976-7): «Torre de Minerva (San Magín). Una torre de la muralla romana de Tarragona”, Bol. Arq. 133-40, 49-74.

HAuschild, T. (1979): «Die römische Stadtmauer von Tarragona. Ausgrabungen in der Torre Minerva und in Baluarte de Sta. Bárbara. Kampagnen 1976 bis 1978», M. M. 20, 204-237. Versión catalana en «La muralla romana de la ciudad de Tarragona. Excavations a la Torre de Minerva i al Baluard de Santa Bárbara; campanyes de 1976 a 1978", Arquitectura romana de Tarragona. Tarragona, 1983, 131-180.

HAUSCHILD, T. (1982): «Muralla romana de Tarragona», Las Excal'ations Arqueologicas a Catalunya en els derniers anys, Barcelona, 350-1.

Huidobro, L. (1929): «Los términos augustales de Sasamón y La Henestrosa», Bol. Comisión Provincial de Monumentos de Burgos 29, 492 y ss.

JONES, R.F.J. (1976): «The Roman military ocupation of North-West Spain», J.R.S. 66, 45-66.

LAMBOGlıA, N. (1955): «Scavi italo-spagnoli de Ampurias», Rivista Studi Liguri XXI, 194-212.

Lamboglia, N. (1958): «Opus Certum», Riv. Studi Liguri XXIV, 158 y ss.

LAMBoglia, N. (1974): «Il probleme delle mure e delle origini di Tarragona» (Conferencia 1952), Miscelánea Arqueológica I. XXV Aniversari d'els Cursos Internacionals de Prehistoria i Arqueologia a Empuries (1947-1971), Barcelona, 397-405.

LE RouX, P. (1977): «Lucus Augusti, capítale administrativa au Haut-Empire», Actas Bimilenario de Lugo, Lugo, 83-107.

LE Roux, P. (1979): «Histoire et Archéologie de la Péninsule Ibérique II. Histoire militare», R.E.A. LXXXI, 160-4).

LE ROUX, P. (1982): L'Armee Romaine et l'organisation des provinces ibériques d'Auguste à l'invasion du 409, París.

LOEWINSOHN, E. (1963): «Una calzada y dos campamentos romanos del Conventus Asturum», A. E. Arq. 38, 26-43.

LUENGO, J. M. (i955): «Astorga (León). Exploración de las cloacas romanas», N.A.H. II, 151 y ss.

LUENGO, J. M. (1961): «Astorga romana. Excavaciones del plan nacional 1954-5». N.A.H. V. 1956$1961,152-177$.

MAGIE, D. (1920): «Augustus war en Spain (26-25 B. C. )», Classical Philology XV, 323-339.

Mañanes, T. (1976): «Asturica Augusta», Symp. Ciudades Augusteas II, Zaragoza, 77-84.

MAÑANES, T. (1982): Epigrafía y numismática de Astorga romana y su entorno, Salamanca.

MAÑANES, T. (1983): Astorga romana y su entorno. Estudio arqueológico, Valladolid.

MAÑANES, T. (1983b): «La implantación romana en el territorio leonés», Lancia 1, León, 139-183.

Mañanes, T. (1984): Asturica Augusta, la ciudad y su entorno», Portugalia IV-V (Actas do Coloquio Interuniversitario de Arqueologia do Noroeste), 215-229.

MAÑANES, T. (1985): «Escavaciones en las murallas de Astorga (1971-2)», N.A.H. 21, 183-219.

MARTín VALLS, R. (1975): «Epígrafes romanos de Sansueña (Rosinos y Santibañez de Vidriales). Sobre los campamentos de Petavonium», Studia Archeologica 36, 13-18.

Martín VAlls, R. y Delibes de Castro, G. (1975): «El campamento de Rosinos de Vidriales». Sobre los campamentos de Petavonium, Studia Archeologica 36, 3-7.

Martín Valls, R. y Delibes de Castro, G. (1975 b): «Nuevo documento militar del campamento de Rosinos de Vidriales», Studia Archeologica 36, 5-12.

MARTín VALLS, R. (1973): "Varia: hallazgos arqueológicos en la provincia de Zamora I», B.S.E.A.A. 39, 408-9.

MARTín VALLS, R. y Delibes, G. (1978): «Varia: hallazgos arqueológicos en la provincia de Zamora II», B.S.E.A.A. 44, 337-339. 
MARTiN VAL.LS, R. y Delibes, G. (1980): «Varia: hallazgos arqueológicos en la provincia de Zamora III", B.S.E.A.A. 46, 120-2.

MARTIN VALLS, R. y Delibes, G. (1981): «Varia: hallazgos arqueológicos en la provincia de Zamora IV $»$, B.S.E.A.A. 47, 117-180.

MARTiN VALLS, R. y Delibes, G. (1982): «Varia: hallazgos arqueológicos en la provincia de Zamora V», B.S.E.A.A. $48,54-62$.

Martín Valls, R. y Delibes de Castro, G. (1990): "Bucculae del campamento de Petavonium», Numantia III, 155-164.

Martínez SANTA-Olall.A. J. (1952): «Las murallas ciclópeas de Tarragona» Bol. Arq. 37-40, 20

MaRTínez GonZalez, J. (1) La campaña de Caton en Hispania, Barcelona, 161-2, y 168.

Mateo Marcos, J. (1979), . . m. Origen, evolución y decadencia de un recinto amurallado», Symp. Nacional Castillos 1978, (repetido en Mateo Marcos, J. Origen, evolución y decadencia del recinto amurallado de León, León, 1981).

MATILLA ViCENTE, E. (1983): «Legio VII Gemina y León», Lancia 1, 263-271.

MELIDA, J. R. (1921): «Informe sobre las murallas de Lugo», Bol Real Academia Bellas Artes, Madrid.

Mezquiriz de Catalán, M. a A. (1954): «Notas sobre la antigua Pompaelo», Rev. Príncipe Viana 6667.

Mezquiriz de Catalán, M. a A. (1958): Pompaelo I. Campaña de 1956. Pamplona.

MeZquiriz de CATALÁN. M. ${ }^{a}$ A. (1976): «Algunas aportaciones al urbanismo de Pompaelo», Symp. Ciudades Augusteas II, Zaragoza, 189-194.

Morillo Cerdan, A. y PÉRez GonZÁlez, C. (1989): «Hallazgos monetarios de Herrera de Pisuerga en colecciones privadas», Actas II Congreso de Historia de Palencia, Palencia, 443-461.

NEUEBAUER, D. (1980): «La construcción megalítica de las murallas ibero-romanas de Tarragona», Bol. Arq. Epoca V, 2, 107-112.

NiETO, G. (1958): El opidum de Iruña, Vitoria, 1958.

PAPIOL MOLNE, L. (1980): «La muralla romana de Tarragona: nuevas aportaciones», Bol. Arq., Epoca V, 2, 113-9.

PASTOR MuÑoz, M. (1976): «Asturica Augusta ¿Fundación de Augusto?», Symp. Ciudades Augusteas, II, Zaragoza, 69-76.

PAulsen, R. (1928): «Die Fundegegenstände aus dem Lager Cáceres», Arch. Anz. 14-30 (Jahrb. Deuts. Arch. Inst.).

PAULSEN, R. (1930): «Die Fundegegenstände aus dem Lager Cáceres», Arch. Anz. 58-67 (Jahrb. Deuts. Arch. Inst.).

Paulsen, R. (1932): «Die Fundegegenstände aus dem Lager Cáceres», Arch. Anz. 348-387 (Jahrb. Deuts. Arch. Inst.).

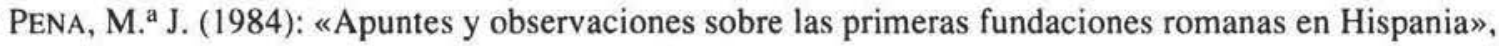
Estudios de la Antigüedad l, Barcelona, 49-85.

PÉREZ GonZÁleZ, C. (1981): «Pisoraca, desde sus orígenes a los visigodos», Publ. Institución Tello Tellez de Meneses, 45,25 y ss.

PÉREZ GONZÁLEZ, C. y FERNÁNDEZ IBÁÑNEZ, C. (1986): «Relaciones entre tres importantes asentamientos del Norte de España: Pisoraca-Iuliobriga-Flaviobriga», I Reunión Arq. Espacial, Teruel 1974, 21 y ss.

PÉRez GonzÁlez, C. (1989): Cerámica romana de Herrera de Pisuerga (Palencia, España). La terra sigillata, Santiago de Chile.

PERICOT, L. (1972): «Schulten y Numancia», Crónica Coloquio Conmemorativo XXI Centenario de la Epopeya numantina, Zaragoza, 31-36.

PETRIKOVITS, H. (1971): «Fortifications in the North-Western roman empire from the third to the fifth centuries», J.R.S. 61, 178-218.

PUIG I CADAFALCH, J. (1934): La arquitectura romana a Catalunya. Barcelona.

RICHMOND, I. A. (1930): «Five town-walls in Hispania Citerior», J.R.S. 21, 86-100. 
RigAud de SousA, J. J. (1973): Subsidios para la carta arqueológica de Braga. Santiago.

De los Ríos y Ríos, A. (1889): "Campamentos romanos de luliobriga", B.R.A.H. XIV. 5(19-514.

RiPOll PERELlo, E. I Llongueras CAMPAÑA, M. (1974): «Embarcadero romano de Riells, en el ámbito empuritano". Miscelánea Arqueológica I. XXV Aniversari dels cursos Int. de Preh. i Arq. a Empuries (19471971), Barcelona, 277-297.

RIPOLl PEREllo, E. (1978): Els origens de la ciutát romana d'Empuries. Discurso leido el dia 8 de Juny de 1978 en la Reial Acadèmia de Bones Lletres de Barcelona. Barcelona.

Roblin, M. (1965): "Cités ou citadelles"? Les enceintes romaines du Bas-Empire d'apres l'exemple de Senlis», R.E.A. LXVIII, 369.

ROdRiguez Colmenero, A. (1977): Galicia Meridional romana. Bilbao, 100-3.

ROdríguez COlmenero, A. (1979): Augusto e Hispania. Conquista y organización del Norte península. Cuad. Univ: Deusto 7, Bilbao,

ROdíguez Colmenero, A. (1980): «El campamento romano de “Aquis Querquenis" (Orense)”, II Seminario Ar. NW., Santiago, 247-260.

ROLdÁN HeRVAS, J. M. (1972-3): «Las Tablas de Barro de Astorga ¿una falsificación moderna?», Zephyrus, 23-4, 221-232.

ROLDÁN HERVAS, J. M. (1974): Hispania y el ejército romano, Salamanca.

ROLDÁN HERVAS, J. M. (1976): «El ejército romano y la romanización de la Península Ibérica», Hist. Antigua $V I, 125-45$.

ROLDÁN HERVAS, J. M. (1983): «La conquista del Norte de Hispania y la participación de los astures en el ejército imperial romano", Lancia 1, 1983, 119-138.

ROLDÁN HERVAS, J. M. (1984): «Ejército y poblamiento en el Norte de la Península Ibérica bajo dominio romano", Mem. Hist. Ant. VI, Oviedo, 67-84.

ROLDÁN HERVAS, J. M. (1986): «La ocupación romana de la Asturia Augustana y la fundación de Astorga», Actas I Cong. Int. Astorga romana, Astorga, 37-53.

ROLDÁN HERVAS, J. M. (1986): «La incidencia del ejército en el poblamiento del Noroeste de Hispania», Ejército y sociedad. Cinco Estudios sobre el mundo antiguo. Ed. A. Del Castillo, León, 11-50.

Rovira Virgili, A. (1922): «Les muralles de Tarragona», Bol. Arq. 7, Tarragona, 170.

SÁNCHEZ-LA FUENTE, J. (1979): «Aportaciones al estudio del campamento romano de «La Cerca» (Aguilar de Anguita, Guadalajara), Wad-al-Hayara 6, 77-82.

SÁNCHEZ-PALENCIA, J. (1986): «El campamento romano de Valdemeda, Manzaneda (León): ocupación militar y explotación aurífera en el Noroeste peninsular», Numantia II, 227-231.

SANMARTI, E. (1973): La cerámica campaniense de Emporion y Rhode. Tesis Doctoral. Barcelona.

Serra Vilaro, I. (1949): "La muralla de Tarragona», A. E. Arq., 221-236.

SChmittenner, W. (1962): «Augustus Spanischer Feldzug der Kampf in der Principat», Historia II, 29-85.

SCHulten, A. (1905): «Ausgrabungen in Numantia I», Archaologischer Anz., 163-6 (en Jahrb. Deuts. Arch. Inst.).

Schulten, A. (1907): "Ausgrabungen in Numantia Il», Arch. Anz., 2-35 en Jahrb. Deuts. Arch. Inst. (trad. francesa en Bulletin Hispanique X, 1908, 128-156).

SChulten, A. (1907 b): «Ausgrabungen in Numantia III», Arch. Anz., $462-486$ en Jahrb. Deuts. Arch. Inst. (trad. francesa Bull. Hispanique XI, 1909, 1-24).

Schulten, A. (1908): «Ausgrabungen in Numantia IV», Arch. Anz., 476-498 en Jahrb. Deuts. Arch. Inst. (trad. francesa Bull. Hisp. XII, 1910, 245-264).

Schulten, A. (1909): «Ausgrabungen in Numantia V», Arch. Anz., 526-547 (en Jahrb. Deuts. Arch. Inst.).

SCHulten, A. (1911): «Ausgrabungen in Numantia VI», Arch. Anz., 3-39 (en Jahrb. Deuts. Arch. Inst.).

SChulten, A. (1912): "Ausgrabungen in Numantia VII", Arch. Anz., 82-99 (en Jahrh. Deuts. Arch. Inst.).

SCHulten, A. (1914): Mis excavaciones en Numancia 1905-1912, Barcelona. (trad. ed. alemana de 1913 en Int. Monoschriften; ed. francesa 1913 en Bull. Hisp. 15).

Schulten, A. (1914 b): Numantia. Die ergebnisse der Ausgrahungen 1906-1912. Vol 1. Die keltiherer und ihre kriege und Rom, Munich. 
SCHt1tEN. A. (1918): "Ein römischer lager aus dem sertorianischen Kriege», Jahrbuch des Deutschen Arch. Instituts, 75-106.

SCHulten, A. (1927): "Forschungen in Spanien" Archaologischen Anzeiger, 197-235 (en Jahrh. Deuts. Arch. Inst.).

SChulten, A. (1927 b): Numantia. Die Ergebnisse der Ausgrabungen 1095-1912. III. Die Lager des Scipio, Munich.

SCHULten, A. (1928): “Campamentos españoles en España». Investigación y Progreso, 5, Mayo, 34-36 (ed. alemana de 1928 en Forschungen und Fortschriften 5, 1-3).

SChulten, A. (1928 b): "Castra Caecilia», Arch. Anz., 1-14 (en Jahrh. Deuts. Arch. Inst.).

SCHulten, A. (1929): Numantia. Die Ergebnisse der Ausgrabungen 1905-1912. IV. Die Lager bei Renieblas, Munich.

Schulten, A. (1930): "Castra Caecilia. Zweiter Bericht». Arch. Anz., 38-58 (en Jahrb. Deuts. Arch. Inst.).

SCHulten, A. (1931): Numantia. Die Ergebnisse der Ausgrabungen 1905-1912. II. Die Stadt Numantia. Munich.

SChulten, A. (1931b): «El campamento del consul Metelo en Cáceres», Investigación y Progreso, año V, n" $1,14-5$

SChulten, A. (1932): «Castra Caecilia», Arch. Anz., 334-348 (en Jahrb. Deuts. Arch. Inst.).

SChulten, A. (1933): "Forschungen in Spanien (1928-1933)», Arch. Anz., 514-566 (en Jahrb. Deuts. Arch. Inst.).

SCHUlten, A. (1943): Los Cántabros y Astures y su guerra con Roma, Madrid.

SCHUlten, A. (1945): Historia de Numancia, Barcelona, (ed. alemana 1933).

SCHULTEN, A. (1949): Sertorio, Barcelona. (ed. alemana 1926).

SYME, R. (1934): «The Spanish war of Augustus (26-25 b. C.)», American Journal Philology LV, 293-317.

SYME, R. (1970): «The conquest of North-West Spain», Legio VII Gemina, León, 83-107.

TARACENA, B. (1939): «Sistema de construcción de los campos atrincherados romanos, según el de Navalcaballo", Sep, Rev. de las Ciencias 1, año IV, Madrid.

TARACENA, B. (1941): Carta arqueológica de España: Soria, Madrid.

TARACENA, B. (1947): «Arte romano: campamentos», Ars Hispaniae II, Madrid, 27-28.

ULBERT, G. (1984): Cáceres el Viejo. Ein späterepublickanisches legionslager in Spanish-Extremadura. Madrider Beitrage $X I$, Mainz.

VÁZQUEZ SEIJAS, M. (1955): Fortalezas de Lugo y su provincia I, Lugo,

VIGIL, M. Y BARBERO, A.: «Sobre los orígenes sociales de la Reconquista: Cántabros y Vascones desde fines del Imperio Romano hasta la invasión musulmana», B.R.A.H. 156. 